
FATECS

PROGRAMA DE INICIAÇÃO CIENTÍFICA

ANDRESSA ROLIM LEMOS

MÉTODOS NÃO DESTRUTIVOS E SEMI-DESTRUTIVOS NA AVALIAÇÃO DE ESTRUTURAS DE CONCRETO ARMADO 


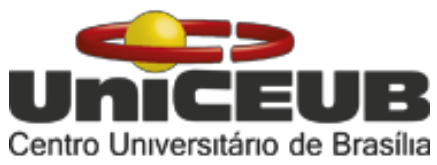

ANDRESSA ROLIM LEMOS

\section{MÉTODOS NÃO DESTRUTIVOS E SEMI-DESTRUTIVOS NA AVALIAÇÃO DE ESTRUTURAS DE CONCRETO ARMADO}

Relatório final de pesquisa de Iniciação Científica apresentado à Assessoria de Pós-Graduação e Pesquisa pela Faculdade de Tecnologia e Ciências Sociais Aplicadas - FCTECS.

Orientador: Prof. Neusa Maria Bezerra Mota, DSc

\section{Brasília}




\title{
MÉTODOS NÃO DESTRUTIVOS E SEMI-DESTRUTIVOS NA AVALIAÇÃO DE ESTRUTURAS DE CONCRETO ARMADO
}

\author{
Andressa Lemos - UniCEUB, PIBITI-CNPq, aluno bolsista \\ andressarlemos@gmail.com
}

\section{Neusa Mota - UniCEUB, professor orientador neusa.mota@uniceub.br}

Brasília tem mais de 50 anos e existe uma preocupação em relação as estruturas de concreto armado das edificações, sendo necessário estudos sobre a deterioração ao longo da vida útil e durabilidade das referidas estruturas. $\mathrm{O}$ objetivo desta pesquisa consiste em estudar os métodos não destrutivos e semi-destrutivos aplicados em estruturas de concreto armado, com mais de 30 anos de idade, localizadas no Plano Piloto de Brasília - DF, a fim de avaliar a deterioração e as anomalias da estrutura, baseado na corrosão de armaduras, resistência a compressão e fissuração. Foram realizados ensaios de medida da frente de carbonatação, com uso da fenolftaleína; dureza superficial pelo esclerômetro, resultando na previsão de resistência a compressão do concreto; medida de cobrimento e bitolas de aço das estruturas de concreto armado, com a técnica de detecção eletromagnética com o pacômetro; velocidade de pulso ultrassônico para análise de fissuração do concreto; e, resistência à compressão do concreto, em laboratório, a partir de testemunhos extraídos. Os ensaios foram executados em duas edificações, a pública, com o objetivo de obter o levantamento da estrutura para realização de reforma mantendo as suas características originais; e, a outra edificação, privada, com o objetivo de obter o diagnóstico das causas das manifestações patológicas. Ao final, baseado na vistoria e ensaios, obteve-se resultados satisfatório de acordo com os respectivos objetivos, além da possibilidade de análise conjunta entre os ensaios realizados em cada estrutura. Para a edificação pública obteve-se índice esclerométrico mínimo de 29,5 e resistência à compressão do concreto média de $22,1 \mathrm{MPa}$, não sendo observadas fissuras e nem corrosão de armaduras na sua estrutura. Na edificação privada temse presença de fissuração em vigas, ausência de corrosão de armaduras em vigas e pilares e índice esclerométrico mínimo em vigas de 41,5 e resistência à compressão média de 39,8 MPa. Concluiu-se que as edificações não apresentaram, ao longo da vida útil, deterioração precoce, e que a pública necessitará de reforço estrutural, devido a execução de reformas, e de recuperação das anomalias pontuadas. A edificação privada demandará recuperação das fissuras estruturais nas vigas bem como, instalação de proteção térmica na cobertura para redução da temperatura, principal causa da fissuração estrutural. Com relação aos equipamentos utilizados na pesquisa, pode-se concluir que o pacômetro e o ultrasom se mostraram adequados ao estudo proposto, no que se refere a tecnologia de detecção de armaduras e condições de fissuração dos elementos estruturais.

Palavras-Chave: Ensaios não destrutivos. Ensaios semi-destrutivos. Concreto armado. 


\section{SUMÁRIO}

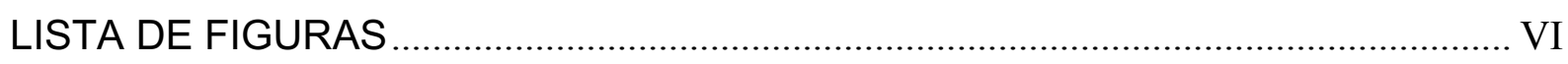

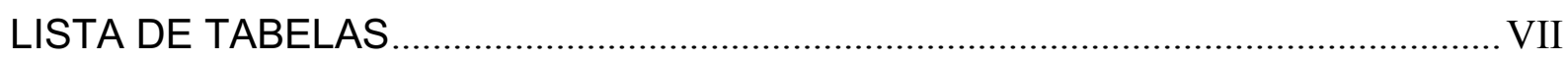

LISTA DE ABREVIATURAS E SÍMBOLOS ...................................................................II

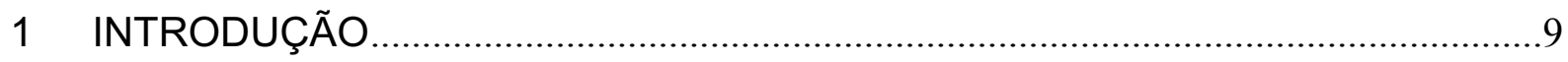

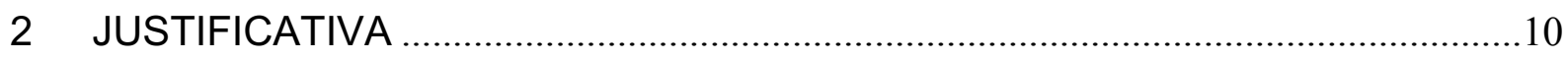

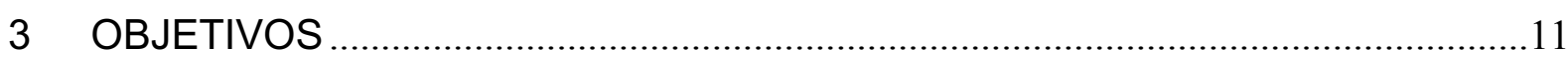

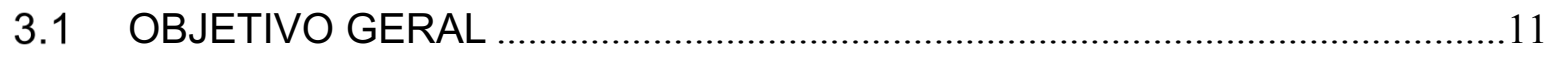

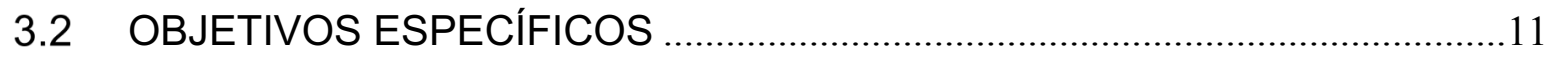

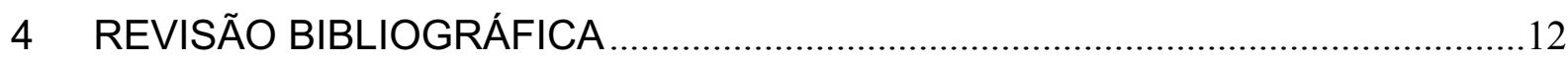

4.1 CAUSAS, MECANISMOS E SINTOMAS DA DEGRADAÇÃO DO CONCRETO ARMADO E DA ARMADURA............................................................12

4.1.1 DESPASSIVAÇÃO DA ARMADURA POR CARBONATAÇÃO ................14

4.1.2 DESPASSIVAÇÃO DA ARMADURA POR AÇÃO DE CLORETOS .........16 4.2 CRITÉRIOS DE PROJETO QUE VISAM A DURABILIDADE DA

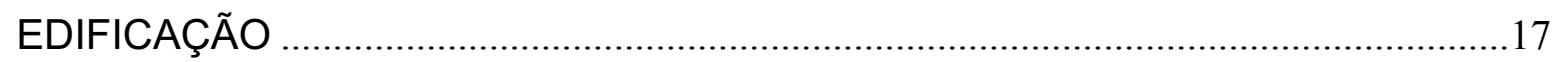

4.3 MÉTODOS NÃO DESTRUTIVOS .................................................................19

4.3.1 MEDIDA DE CARBORNATAÇÃO .........................................................19

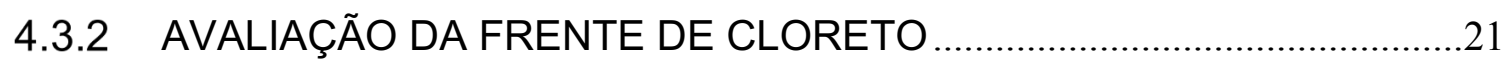

4.3.3 DETECÇÃO ELETROMAGNÉTICA DA ARMADURA..............................22

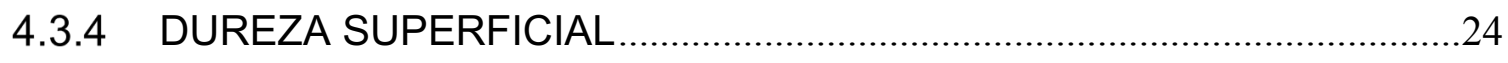

4.3.5 VELOCIDADE DE PULSO ULTRASSÔNICO...............................................28

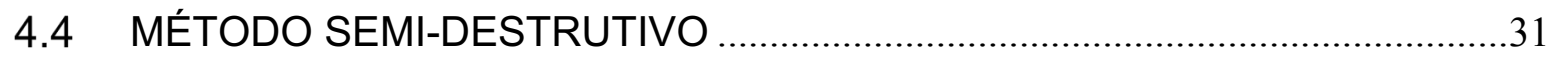

4.4.1 EXTRAÇÃO DO TESTEMUNHO E RESISTÊNCIA A COMPRESSÃO EM CORPO DE PROVA DE CONCRETO ………...............................................

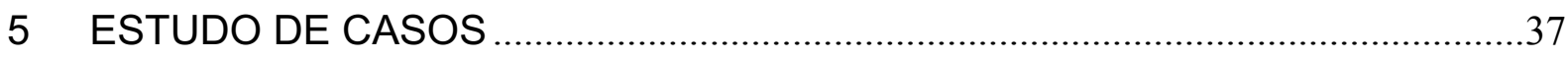

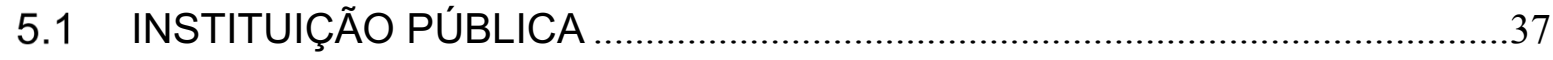




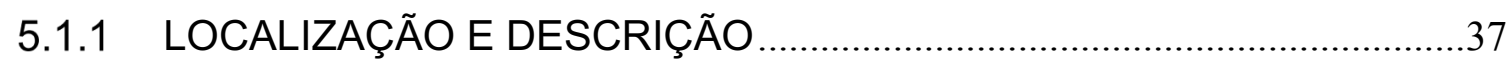

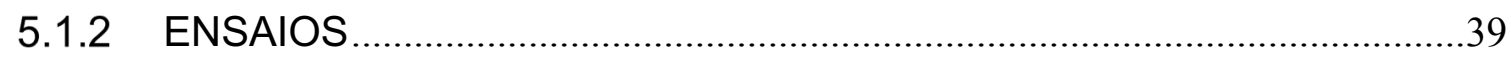

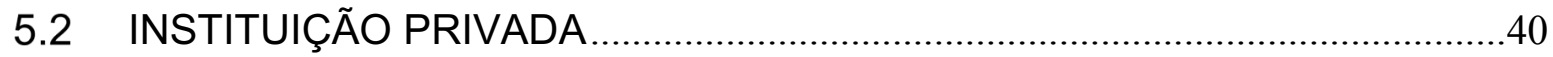

5.2.1 LOCALIZAÇÃO E DESCRIÇÃO ……………………………………….........

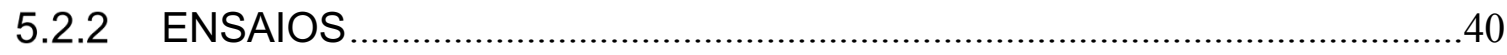

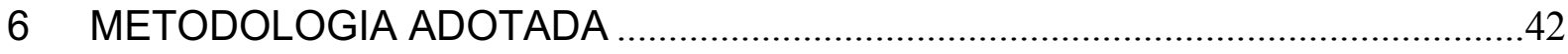

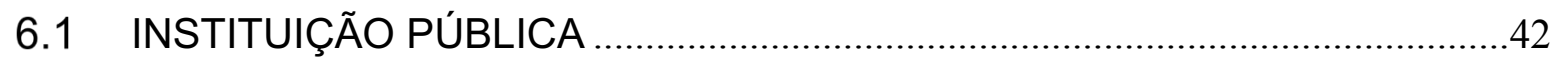

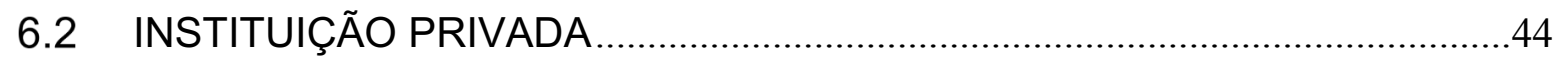

7 APRESENTAÇÃO E ANÁLISE DOS RESULTADOS …………………………........45

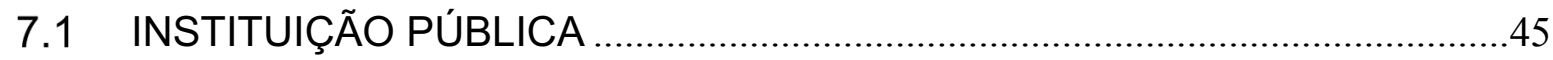

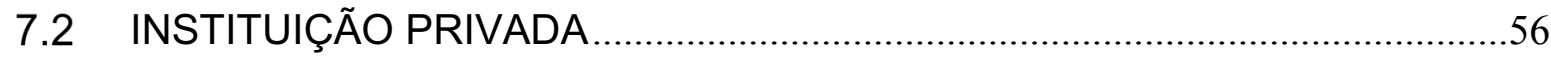

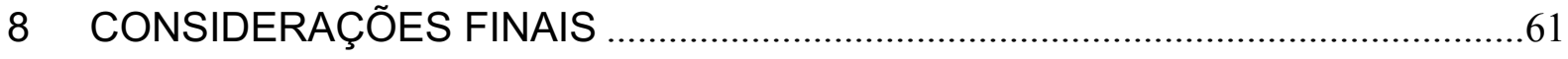

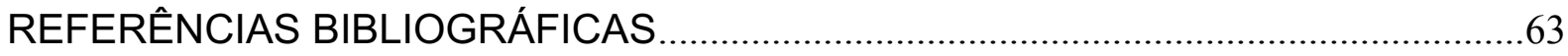




\section{LISTA DE FIGURAS}

Figura 4.1 - Representação do avanço da frente de carbonatação ..............................14

Figura 4.2 - Influência da umidade relativa no grau de carbonatação ...........................15

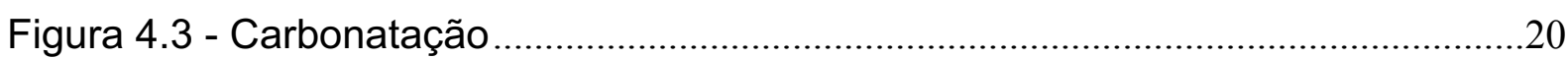

Figura 4.4 - Avaliação da frente de cloreto por aspersão de indicador à base de

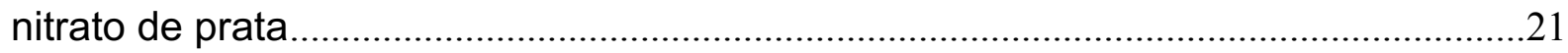

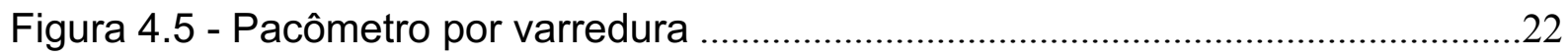

Figura 4.6 - Ilustração da sequência de execução do ensaio de esclerometria...........24

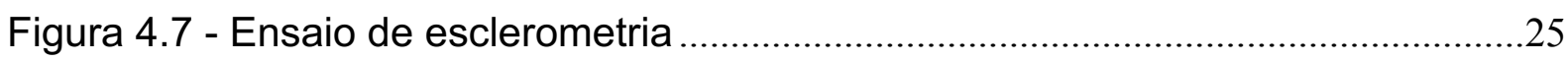

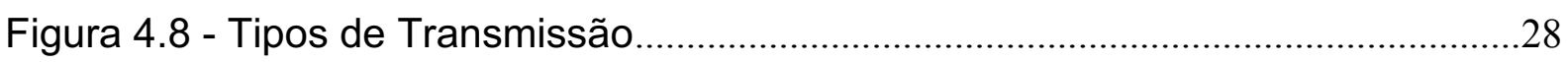

Figura 4.9 - Equipamento de extração de testemunhos de concreto..............................32

Figura 4.10 - Fluxograma da análise dos resultados da extração .................................36

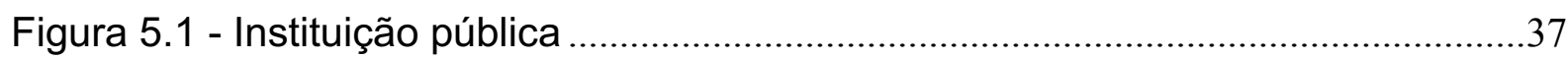

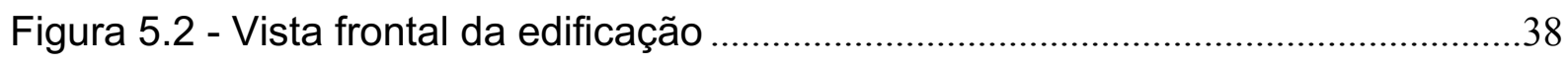

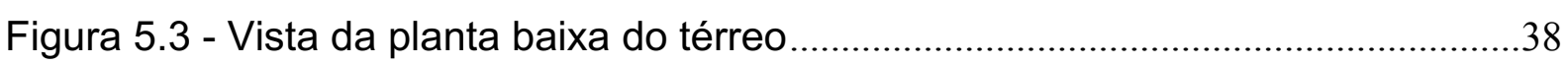

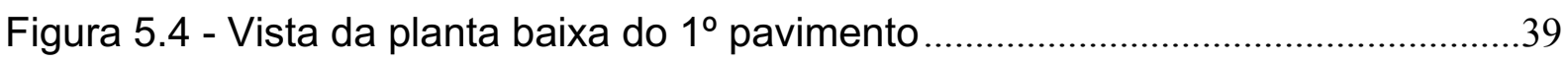

Figura 5.5 - Setor Terminal Norte, Quadra 716, Conjunto C ........................................40

Figura 6.1 - Fluxograma da metodologia a seu utilizada..............................................42

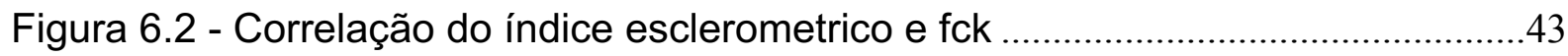

Figura 6.3 - Gráfico de correlação de Esclerometria.....................................................45

Figura 7.1 - Ferragem exposta na garagem .................................................................46

Figura 7.2 - Tubulação indevidamente exposta ...........................................................46

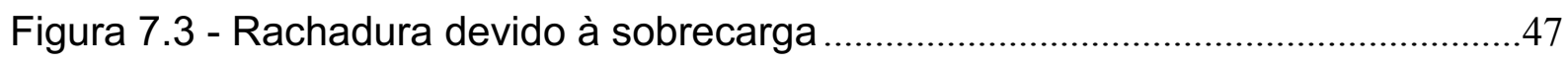

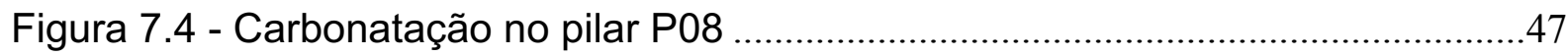

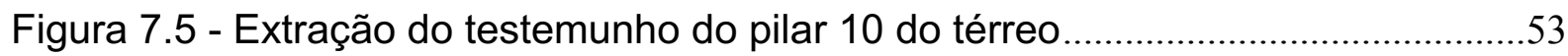

Figura 7.6 - Extração de testemunho do pilar 20 do $1^{\circ}$ Pavimento .................................54

Figura 7.7 - Extração do testemunho do pilar 22 do térreo.............................................54

Figura 7.8 - Rompimento do testemunho do Pilar 10 .....................................................54

Figura 7.9 - Resultados de resistência obtido pelos ensaios realizados .......................56

Figura 7.10 - Ensaio de esclerometria da instituição privada .......................................58

Figura 7.11 - Extração do corpo-de-prova da instituição privada .................................58

Figura 7.12 - Extração do testemunho da instituição privada..........................................58

Figura 7.13 - Ensaio de resistência à compressão simples .........................................59 
Figura 7.14 - Testemunhos rompidos Erro! Indicador não definido.

Figura 7.15 - Comparação do ensaio de esclerometria e de resistência a compressão

\section{LISTA DE TABELAS}

Tabela 4.1 - Causas, mecanismos e sintomas da deterioração do concreto armado 13 Tabela 4.2 - Classes de agressividade ambiental (CAA)...

Tabela 4.3 - Correspondência entre a classe de agressividade e a qualidade do concreto

Tabela 4.4 - Correspondência entre a classe de agressividade ambiental e o cobrimento nominal com tolerância de $10 \mathrm{~mm}$

Tabela 4.5 - Vantagens e desvantagens da utilização do método de aspersão de fenolftaleína

Tabela 4.6 - Vantagens e desvantagens do método de aspersão de indicador à base de nitrato de prata

Tabela 4.7 - Vantagens e desvantagens do método de detecção eletromagnética da armadura

Tabela 4.8 - Vantagens e desvantagens do método de dureza superficial.....

Tabela 4.9 - Relação entre velocidade de propagação e a qualidade do concreto....30

Tabela 4.10 - Vantagens e desvantagens do método de pulso ultrassônico..... .31

Tabela 4.11 - Coeficiente de correção em relação h/d (k1).

Tabela 4.12 - Coeficiente de correção do bronqueamento em função do diâmetro do testemunho $(\mathrm{k} 2)$

Tabela 4.13 - Valores do coeficiente yc

Tabela 4.14 - Vantagens e desvantagens do método de resistência a compressão em testemunho de concreto.

Tabela 7.1 - Índice esclerométrico e quantidade de ferragens na zona 1

Tabela 7.2 - Índice esclerométrico e quantidade de ferragens na zona 2

Tabela 7.3 - Índice esclerométrico e quantidade de ferragens na zona 3

Tabela 7.4 - Índice esclerométrico e quantidade de ferragens na zona 4 .51

Tabela 7.5 - Índice esclerométrico e quantidade de ferragens na zona 4 .52

Tabela 7.6 - Índice esclerométrico e quantidade de ferragens na zona 5. .53

Tabela 7.7- Resistência a compressão .55

Tabela 7.8 - Resultados da Esclerometria no INFRA 1 
Tabela 7.9 - Resultados da Esclerometria no INFRA 2 …...........................................57

Tabela 7.10 - Resultados de resistência à compressão do concreto.............................59

\section{LISTA DE ABREVIATURAS E SÍMBOLOS}

$\mathrm{ACl} \quad$ American Concrete Institute

ABNT Associação Brasileira de Normas Técnicas

NBR Norma Brasileira

IE Índice Esclerométrico

$1^{\circ} \mathrm{GBM} \quad 1^{\circ} \mathrm{Grupamento}$ de Bombeiros Militar do Distrito Federal 


\section{INTRODUÇÃO}

$\mathrm{Na}$ Capital, a preocupação com a sua conservação vem desde a implantação da cidade em 1960, e consta da Lei Santiago Dantas que estabeleceu a organização administrativa do Distrito Federal (Art. 38 da Lei $n^{\circ} 3.751 / 60$ ). Brasília foi reconhecida como patrimônio cultural da humanidade pela UNESCO em 1987, tombada como patrimônio histórico federal em 1990 e pelo Governo do Distrito Federal em 1991. Devido ao fato de Brasília ter mais de 50 anos, existe uma preocupação em relação as estruturas de concreto armado das edificações, muitas vezes aparentes, sendo necessário estudos sobre a deterioração ao longo da vida útil e durabilidade das referidas estruturas.

A utilização de métodos não destrutivos e semi-destrutivos na análise de deterioração de estruturas é de suma importância na otimização de recursos e tempo, com poucas perturbações as estruturas, mantendo-as mais intactas possíveis. A metodologia proposta irá auxiliar na identificação das manifestações patológicas, qualidade do concreto armado e sua deterioração ao longo da vida útil, dentre outros quesitos necessários ao diagnóstico e prognóstico dos edifícios. O uso dos métodos propostos nesta pesquisa traz ganho para o meio ambiente, pois com base nos resultados destes ensaios é possível definir a integridade de uma estrutura, e detectar, em fase inicial, as possíveis manifestações patológicas que possam surgir, para que seja possível a intervenção preventiva, de modo a obter uma redução nos custos de manutenção e resíduos para o meio ambiente. Pode-se observar que os países desenvolvidos têm um olhar peculiar para revitalização de estruturas.

Em 1991, o Departamento de Transporte dos Estados Unidos relatou que
90 bilhões de dólares foram gastos na recuperação e reforma do sistema de
infraestrutura rodoviária. Até 1997, esses custos haviam subido para 212
bilhões de dólares. O impacto econômico previsto para uma ampla
recuperação dessa infraestrutura tem levado a um interesse crescente pelo
aperfeiçoamento de métodos de ensaios não destrutivos para a avaliar
estruturas de concreto. (Mehta, 2014; Monteiro, 2014, p. 423).

Com relação as pesquisas realizadas nos últimos anos, que utilizaram a metodologia de ensaios destrutivos e não destrutivos, pode-se destacar os trabalhos a seguir, que demonstram o estado da arte atual, em termos de pesquisas científicas.

Câmara (2006) caracterizou de diferentes tipos de concreto usualmente utilizados na Grande Florianópolis, mediante o uso dos ensaios não destrutivos de 
ultra-som, penetração de pinos, esclerometria e maturidade, traçando correlações com a resistência à compressão.

Sahuinco (2011) fez avaliação de uma ponte de concreto armado através do uso de métodos de ensaios não destrutivos e semi-destrutivos e estabeleceu uma comparação entre os resultados da inspeção visual e resultados do uso de métodos de ensaio, sob o ponto de vista da durabilidade.

Santos (2012) publicou em sua dissertação um estudo de casos, utilizando ensaios destrutivos e semi- destrutivos.3261

\section{JUSTIFICATIVA}

Este projeto de iniciação científica é parte integrante de um projeto de pesquisa mais amplo, intitulado "Edifícios residenciais das superquadras 400: programa piloto referente aos aspectos históricos, científicos e tecnológicos de projeto, intervenções, diagnóstico e propostas de manutenção", iniciado em 2013, no UniCEUB, coordenado pela Prof ${ }^{\mathrm{a}}$ Neusa Maria Bezerra Mota, que em seus objetivos propõe a realização de inspeções e ensaios para caracterização de elementos estruturas e a quantificação do grau de deterioração das estruturas.

Neste contexto, entende-se que sendo o concreto o principal material utilizado na construção dos edifícios pertencentes ao Plano Piloto, pela facilidade de se obter elementos estruturais de formas e tamanho diferentes, resistência adequada, durabilidade significativa, disponibilidade e baixo custo, é notável que ao longo do tempo a sua deterioração vem comprometendo o desempenho das estruturas, sendo necessário as inspeções periódicas para verificação da integridade dos elementos estruturais e para definição das intervenções necessárias.

No entanto, nas estruturas mais antigas, além da dificuldade de se obter a documentação técnica necessária a inspeção, que exigirá o levantamento desta estrutura em função da deficiência de seus projetos, faz-se necessária, também, uma análise mais aprofundada com relação a deterioração, seja por ações mecânicas, físicas, químicas ou eletroquímicas no concreto armado ao longo do tempo. Neste momento, se torna imprescindível a utilização dos métodos nãodestrutivos e semi-destrutivos, que permitirá uma análise geral da estrutura, com mapeamento mais completo, sem que haja um comprometimento da estrutura já deteriorada. 


\section{OBJETIVOS}

\subsection{OBJETIVO GERAL}

O objetivo desta pesquisa consiste em estudar os métodos não destrutivos e semi-destrutivos e aplica-los em estruturas de concreto armado com mais de 30 anos de idade, localizadas no Plano Piloto de Brasília - DF, a fim de obter medida da frente de carbonatação, com uso da fenolftaleína; dureza superficial pelo esclerômetro, resultando na previsão de resistência a compressão do concreto; medida de cobrimento e bitolas de aço das estruturas de concreto armado com a técnica de detecção eletromagnética (aparelho pacômetro); velocidade de pulso ultrassônico para análise de fissuração do concreto e por fim, a obtenção da resistência a compressão do concreto, em laboratório, a partir de testemunhos extraídos do concreto.

\subsection{OBJETIVOS ESPECÍFICOS}

- Revisão bibliográfica das principais manifestações patológicas;

- Revisão bibliográfica de critérios de projeto que visam a durabilidade do concreto;

- Revisão bibliográfica de métodos não destrutivos e semi-destrutivos;

- Inspeção de um prédio púbico com objetivo de fazer uma reforma mantendo as características da edificação;

- Análise de prédio privado a fim de descobrir as causas das manifestações patológicas;

- Execução dos ensaios destrutivos e não-destrutivos em ambas as edificações;

- Utilização da tecnologia dos equipamentos de pacômetria e de ultra-som para a análise da edificação;

- Análise comparativa dos resultados obtidos para o entendimento da deterioração das estruturas ao longo do tempo. 


\section{REVISÃO BIBLIOGRÁFICA}

$\mathrm{Na}$ análise das manifestações patológicas, é necessário a realização de ensaios que possam caracterizar o nível de deterioração da estrutura. Estes correspondem aos métodos não destrutivos e semi-destrutivos e são comumente utilizados por proporcionarem dados importantes para a análise do elemento estrutural, possibilitarem a aplicação com a edificação em uso e causarem danos pequenos ou nulos na estrutura.

Nesta pesquisa trataremos os métodos não destrutivos como os métodos que os impactos nas estruturas são pequenos ou nulos, os quais não são necessários uma análise posterior a sua aplicação. Já o método semi-destrutivo, de qualquer forma necessita-se de uma reparação e análise da estrutura após a aplicação.

Para a realização dos ensaios é necessário, primeiramente, fazer uma inspeção predial, que consiste, de acordo com a Norma de Inspeção Predial do IBAPE/SP, a "análise isolada ou combinada das condições técnicas, de uso e de manutenção da edificação". Contudo, entende-se que a inspeção predial é uma vistoria mais aprofundada, o qual utiliza técnicas e aparelhos para a análise.

No entanto, para a realização dos ensaios é necessário o conhecimento das manifestações patológicas, assim como suas causas, mecanismos e sintomas da degradação do concreto e da armadura. Também deve-se verificar os critérios de projeto que visam a durabilidade da edificação conforme a ABNT NBR 6118,2014.

\subsection{CAUSAS, MECANISMOS E SINTOMAS DA DEGRADAÇÃO DO CONCRETO ARMADO E DA ARMADURA}

Souza e Ripper (1998) afirma que é indispensável o conhecimento das causas da deterioração do concreto, pois, além de identifica-los corretamente e realizar os reparos exigidos, também garante que, depois de reparada, a estrutura não volte a se deteriorar.

No entanto, existe quatro principais causas responsáveis pela redução da durabilidade do concreto armado e da armadura, os quais podem ser classificadas, de acordo com sua natureza, em (Santos,2012):

$>\quad$ Causas mecânicas;

> Causas físicas; 
Causas químicas;

Causa eletroquímica (referente à corrosão eletroquímica).

Tabela 4.1 - Causas, mecanismos e sintomas da deterioração do concreto armado

\begin{tabular}{|c|c|c|c|c|c|}
\hline $\begin{array}{c}\text { CAUSA DA } \\
\text { DETERIORAÇÃO }\end{array}$ & \multicolumn{3}{|c|}{ MECANISMOS DE DETERIORAÇÃO } & SINTOMAS & $\begin{array}{c}\text { AFETA } \\
\text { DIRETAMENTE }\end{array}$ \\
\hline \multirow{3}{*}{ MECÂNICA } & \multicolumn{3}{|c|}{ CHOQUES E IMPACTOS } & \multirow{3}{*}{$\begin{array}{c}\text { Fissuração e lascamento do } \\
\text { concreto; possivel perda de } \\
\text { armadura } \\
\end{array}$} & \multirow{3}{*}{$\begin{array}{c}\text { Peça estrutural } \\
\text { (concreto + armadura) }\end{array}$} \\
\hline & \multicolumn{3}{|c|}{ RECALQUE DIFERENCIAL DAS FUNDAÇõES } & & \\
\hline & \multicolumn{3}{|c|}{ ACIDENTES IMPREVISÍVEIS } & & \\
\hline \multirow{9}{*}{ FÍSICA } & \multirow{3}{*}{ DESGASTE SUPERFICIAL } & & ABRASÃo & \multirow{3}{*}{$\begin{array}{l}\text { Desgaste superficial do } \\
\text { concreto }\end{array}$} & \multirow{3}{*}{ Concreto } \\
\hline & & ATRITO & EROSÃo & & \\
\hline & & \multicolumn{2}{|c|}{ CAVITAÇÃO } & & \\
\hline & \multicolumn{3}{|c|}{ CRISTALIZAÇÃO DE SAIS NOS POROS DO CONCRETO } & $\begin{array}{l}\text { Fissuraçãa e escamamento } \\
\text { do concreto }\end{array}$ & Concreto \\
\hline & \multirow{2}{*}{$\begin{array}{l}\text { RETRAÇ̃̃o HIDRÁULICA DO } \\
\text { CONCRETO FRESCO }\end{array}$} & \multirow{2}{*}{\multicolumn{2}{|c|}{\begin{tabular}{|c|} 
ASSENTAMENTO PLÁSTICO \\
RETRAÇÃo PLÁSTICA \\
\end{tabular}}} & \multirow{2}{*}{ Fissuração do concreto } & \multirow{2}{*}{ Concreto } \\
\hline & & & & & \\
\hline & \multirow{2}{*}{ GRADIENTE TÉRMICO } & RETRAC & TÉRMICA & \multirow{2}{*}{ Fissuração do concreto } & \multirow{2}{*}{ Concreto } \\
\hline & & \multicolumn{2}{|c|}{ DILATAÇÃO TÉRMICA } & & \\
\hline & \multicolumn{3}{|c|}{ AÇÃO DO FOGO (INCÊNDIO) } & $\begin{array}{c}\text { Fissuração; desidratação da } \\
\text { pasta de cimento; expansão } \\
\text { dos agregados; e } \\
\text { desagregação do concreto; } \\
\text { ruptura e colapso da } \\
\text { armadura } \\
\end{array}$ & $\begin{array}{c}\text { Peça estrutural } \\
\text { (concreto + armadura) }\end{array}$ \\
\hline \multirow{7}{*}{ QUÍMICA } & \multicolumn{3}{|c|}{ REAÇÃo ÁLCALI-AGREGADO } & \multirow{2}{*}{$\begin{array}{c}\text { Expansão e fissuração do } \\
\text { concreto }\end{array}$} & \multirow{2}{*}{ Concreto } \\
\hline & \multicolumn{3}{|c|}{ HIDRATAÇ̃̃o DOS ÓXIDOS DO CIMENTO MgO e CaO } & & \\
\hline & \multicolumn{3}{|c|}{ ATAQUE POR SULFATOS } & $\begin{array}{l}\text { Decomposição química da } \\
\text { pasta; despassivação do aço; } \\
\text { expansão, fissuração, } \\
\text { desintegração, perda de } \\
\text { resistência e de massa do } \\
\text { concreto }\end{array}$ & Concreto \\
\hline & \multicolumn{3}{|c|}{ ATAQUE POR ÁCIDOS } & $\begin{array}{l}\text { Decomposição química, } \\
\text { dissolução e lixiviação; ou } \\
\text { decomposição química, } \\
\text { expansão, fissuração e } \\
\text { desagregação do concreto }\end{array}$ & $\begin{array}{c}\text { Concreto } \\
\text { (o } \mathrm{HCl} \text {, por sua vez, ataca } \\
\text { ambos - concreto e aço) }\end{array}$ \\
\hline & \multicolumn{3}{|c|}{ ÁGUA PURA } & $\begin{array}{l}\text { Decomposição química, } \\
\text { dissolução e lixiviação da } \\
\text { pasta de cimento; } \\
\text { eflorescência, estalactite e } \\
\text { estalagmite }\end{array}$ & Concreto \\
\hline & \multicolumn{3}{|c|}{ CARBONATAÇÃO } & $\begin{array}{c}\text { Redução progressiva do } \mathrm{pH} \\
\text { do concreto e } \\
\text { despassivação do aço, } \\
\text { abrindo caminho para a } \\
\text { corrosão do aço } \\
\end{array}$ & $\begin{array}{l}\text { Inicialmente o concreto; } \\
\text { posteriormente } o \text { aço }\end{array}$ \\
\hline & \multicolumn{3}{|c|}{ ATAQUE POR CLORETOS } & $\begin{array}{c}\text { Despassivação do aço; } \\
\text { posteriormente, corrosão } \\
\text { das armaduras (processo } \\
\text { eletroquímico) }\end{array}$ & $\begin{array}{c}\text { Inicialmente } o \text { aço; } \\
\text { posteriormente o concreto }\end{array}$ \\
\hline ELETROQUÍMICA & \multicolumn{3}{|c|}{ CORROSÃO DAS ARMADURAS } & $\begin{array}{l}\text { Deterioração e perda de } \\
\text { seção do aço; perda da } \\
\text { aderência aço-concreto; } \\
\text { expansão, fissuração e } \\
\text { lascamento do concreto }\end{array}$ & $\begin{array}{c}\text { Inicialmente } o \text { aço; } \\
\text { posteriormente o concreto }\end{array}$ \\
\hline
\end{tabular}

Fonte: Andrade (2005) e Andrade e Silva (2005) apud Santos (2012). 
Neste trabalho, são abordadas algumas manifestações patológicas comumente identificadas através de métodos não destrutivos e semi-destrutivos, conforme a seguir:

\subsubsection{DESPASSIVAÇÃO DA ARMADURA POR CARBONATAÇÃO}

Segundo Cunha e Helena (2001), o concreto em boas qualidades normalmente possui pH entre 12,5 e 13,5, pH alcalino, e a sua função é proteger a armadura a partir de uma película passivadora que é formada ao redor da ferragem. No concreto, existe a presença de hidróxido de cálcio, $\mathrm{Ca}(\mathrm{OH})_{2}$, que em contato com o meio, onde possui dióxido de carbono, $\mathrm{CO}_{2}$, produz o carbonato de cálcio, $\mathrm{CaCO}_{3}$, juntamente com a água, processo chamado de carbonatação (4.1). Este processo abaixa o $\mathrm{pH}$ do meio, formando uma frente de carbonatação que quando percorrido todo o cobrimento da ferragem ocorre a despassivação da armadura. Após a sua despassivação, a corrosão do aço é iniciada na presença de água e oxigênio.

Equação química da carbonatação:

$$
\mathrm{Ca}(\mathrm{OH})_{2}+\mathrm{CO}_{2} \rightarrow \mathrm{CaCO}_{3}+\mathrm{H}_{2} \mathrm{O} \downarrow \mathrm{pH}
$$

Figura 4.1 - Representação do avanço da frente de carbonatação

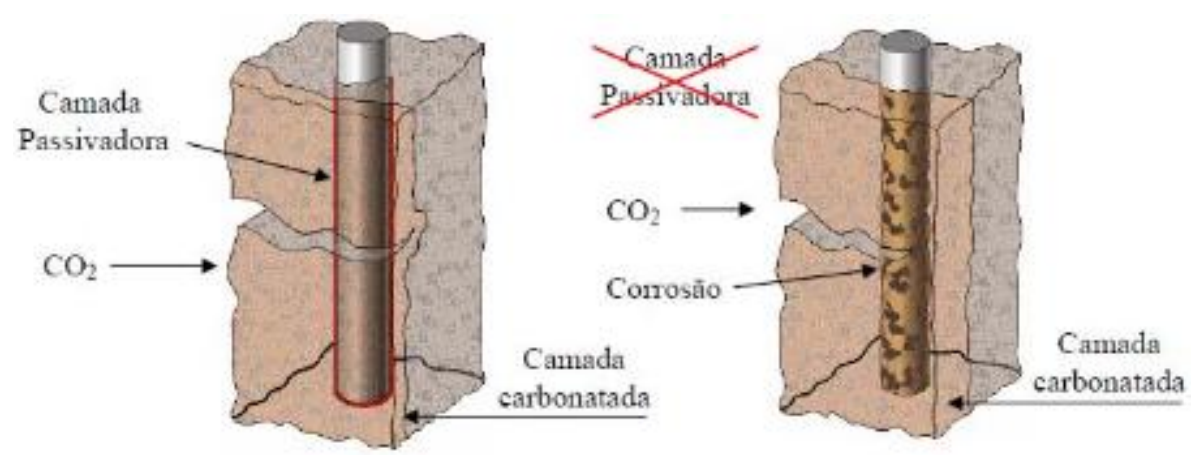

Fonte: Tula, 2000.

A carbonatação depende de fatores como:

a) Condições ambientais;

Altas concentrações de $\mathrm{CO}_{2}$ aumentam as chances de ataque ao concreto.

b) Umidade do ambiente; 
Poros parcialmente preenchidos com água na superfície do concreto apresentam condição favorável.

Quando os poros estão secos, o $\mathrm{CO}_{2}$ difunde até ás regiões mais internas sem dificuldades. Porém, a reação de carbonatação não ocorre devido à falta de água. Quando os poros estão cheios de água, a frente de carbonatação é freada devido à baixa velocidade da difusão do $\mathrm{CO}_{2}$ na água. Em poros parcialmente preenchidos com água, a frente de carbonatação avança devido à coexistência dos dois fatores; água e possibilidade de difusão de $\mathrm{CO}_{2}$. (Andrade, 1992).

Segundo CEB / BI (1982) apud Figueiredo (2005), as maiores taxas de carbonatação ocorrem quando a umidade relativa do ar se situa entre $50 \% \mathrm{e}$ $60 \%$. Por outro lado, com umidades inferiores a $20 \%$ ou superiores a $95 \%$, a carbonatação ocorre lentamente, ou simplesmente não ocorre (Figura 4.2).

Figura 4.2 - Influência da umidade relativa no grau de carbonatação

Fonte: Figueiredo (2005) apud Polito (2006).

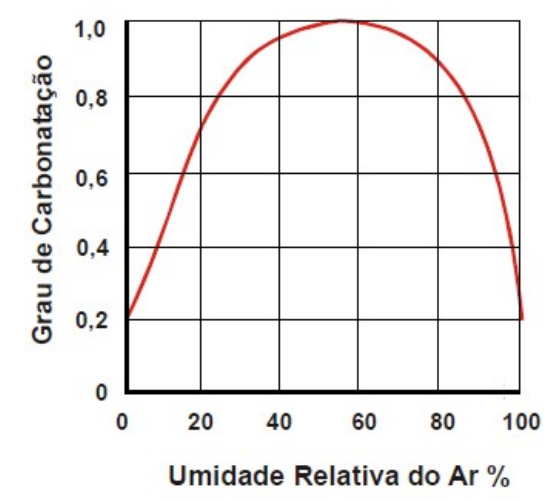

c) Traço do concreto;

Altas relações água cimento, resultam em concretos porosos e, portanto, aumentam as chances de difusão de $\mathrm{CO}_{2}$ entre os poros.

d) Lançamento e adensamento;

Se o concreto tiver baixa permeabilidade (compacto), dificultará a entrada de agentes agressivos.

e) Cura;

Concreto mal curado possui microfissuras que o enfraquecem, estas facilitam a entrada de dióxido de carbono, $\mathrm{CO}_{2}$, acelerando a carbonatação. Segundo Adam Neville (2016), através de pesquisas observou-se que o aumento do período da cura, ampliando a molhagem de um dia para três dias, reduziu a profundidade de carbonatação em cerca de $40 \%$. 


\subsubsection{DESPASSIVAÇÃO DA ARMADURA POR AÇÃO DE CLORETOS}

De acordo com França (2011), o cloreto no concreto e na argamassa pode ser proveniente dos agregados, da água ou do solo contaminado, do aditivo acelerador de pega à base desse íon, dos sais de degelo, das atmosferas marinhas ou da ação direta da água do mar.

França afirma também que a corrosão induzida por cloretos é o tipo mais perigoso, pois os cloretos despassivam a armadura pontualmente, ainda que o $\mathrm{pH}$ esteja elevado, e formam pites, que reduzem a seção transversal da barra, diminuindo sua capacidade portante e, podem levar a estrutura ao colapso.

A ação do cloreto pode ocorrer tanto no concreto, quanto no aço; No concreto, o íon cloreto $\left(\mathrm{Cl}^{-}\right)$reage com a água $\left(\mathrm{H}_{2} \mathrm{O}\right)$ e transforma em ácido clorídrico $(\mathrm{HCl})$ e oxigênio $\left(\mathrm{O}_{2}\right)$, ou seja, o ácido clorídrico baixa o $\mathrm{pH}$ do concreto e, assim, quebra a camada passivadora do aço quando percorrido todo o cobrimento da armadura (4.2). A atuação do cloreto no aço ocorre reagindo com o ferro $\left(\mathrm{Fe}^{2+}\right)$, formado na presença de água, e resultando no cloreto férrico que é muito instável, ou seja, o cloreto férrico reage com a hidroxila $\left(\mathrm{OH}^{-}\right)$, resultante da reação da água com o oxigênio, gerando o hidróxido de ferro $\left(\mathrm{Fe}(\mathrm{OH})_{2}\right)$ e novamente no cloreto, dessa forma esse ciclo resulta em corrosão localizada, o qual o cloreto se tornar um catalisador.(4.3).

Equação química da frente de cloreto do aço por ação do cloreto:

$$
\mathrm{Cl}^{-}+\mathrm{H}_{2} \mathrm{O} \rightarrow \mathrm{HCl}+\mathrm{O}_{2} \downarrow p \mathrm{H}
$$

Frente de cloreto

Equação química da corrosão localizada:

$$
\begin{gathered}
\mathrm{Fe} \rightarrow \mathrm{Fe}^{++}+2 e^{-} \\
2 \mathrm{Cl}^{-}+\mathrm{Fe}^{++} \rightarrow \mathrm{FeCl}_{2} \\
2 e^{-}+\mathrm{O}_{2}+2 \mathrm{H}_{2} \mathrm{O} \rightarrow 4\left(\mathrm{OH}^{-}\right) \\
\mathrm{FeCl}_{2}+2 \mathrm{OH}^{-} \rightarrow \mathrm{Fe}(\mathrm{OH})_{2}+2 \mathrm{Cl}^{-}
\end{gathered}
$$

Corrosão localizada 


\subsection{CRITÉRIOS DE PROJETO QUE VISAM A DURABILIDADE DA EDIFICAÇÃO}

Indiscutivelmente, nos últimos anos, a questão da qualidade tem sido bastante evidenciada, tanto no Brasil como no exterior, seja devido à maior exigência por parte dos usuários ou à maior preocupação dos poderes públicos com relação à adequação ao uso, à durabilidade das estruturas e benefícios ao meio ambiente (Brandão, 1998).

Segundo a ABNT NBR 6118:2014, durabilidade consiste na capacidade da estrutura resistir às influências ambientais previstas e definidas em conjunto pelo autor do projeto estrutural e o contratante, no início dos trabalhos de elaboração do projeto. As estruturas de concreto devem ser projetadas e construídas de modo que, sob as condições ambientais previstas na época do projeto e quando utilizadas conforme preconizado em projeto, conservem sua segurança, estabilidade e aptidão em serviço durante o prazo correspondente à sua vida útil.

Nessa perspectiva, a vida útil de projeto, entende-se, conforme a ABNT NBR 6118:2014, o período de tempo durante o qual se mantêm as características das estruturas de concreto, sem intervenções significativas, desde que atendidos os requisitos de uso e manutenção prescritos pelo projetista e pelo construtor, bem como de execução dos reparos necessários decorrentes de danos acidentais.

De acordo com a ABNT NBR 6118:2014, as estruturas de concreto devem ser projetadas e construídas de modo que, sob as condições ambientais previstas na época do projeto e quando utilizadas conforme preconizado em projeto, conservem sua segurança, estabilidade e aptidão em serviço durante o prazo correspondente à sua vida útil.

Dessa forma, agressividade do meio é um aspecto de suma importância quando se trata de construção, o qual está relacionado às ações físicas e químicas que atuam sobre a estrutura de concreto correspondentes as condições ambientais que interfere significativamente a durabilidade da edificação, este é classificado pela tabela 4.2: 
Tabela 4.2 - Classes de agressividade ambiental (CAA)

\begin{tabular}{|c|c|c|c|c|}
\hline & $\begin{array}{l}\text { Classe de } \\
\text { agressividade } \\
\text { ambiental }\end{array}$ & Agressividade & $\begin{array}{l}\text { Classificação geral do tipo de } \\
\text { ambiente para efeito de projeto }\end{array}$ & $\begin{array}{l}\text { Risco de } \\
\text { deterioração da } \\
\text { estrutura }\end{array}$ \\
\hline \multirow{2}{*}{\multicolumn{2}{|c|}{ I }} & \multirow{2}{*}{ Fraca } & Rural & \multirow{2}{*}{ Insignificante } \\
\hline & & & Submersa & \\
\hline & II & Moderada & Urbana $^{a, b}$ & Pequeno \\
\hline \multirow{2}{*}{\multicolumn{2}{|c|}{ III }} & \multirow{2}{*}{ Forte } & Marinha ${ }^{a}$ & \multirow{2}{*}{ Grande } \\
\hline & & & Industrial a, b & \\
\hline \multirow{2}{*}{\multicolumn{2}{|c|}{ IV }} & \multirow{2}{*}{ Muito forte } & Industrial a, c & \multirow{2}{*}{ Elevado } \\
\hline & & & Respingos de maré & \\
\hline \multicolumn{5}{|c|}{$\begin{array}{l}\text { Pode-se admitir um microclima com uma classe de agressividade mais branda (uma classe acima) para } \\
\text { ambientes internos secos (salas, dormitórios, banheiros, cozinhas e áreas de serviço de apartamentos } \\
\text { residenciais e conjuntos comerciais ou ambientes com concreto revestido com argamassa e pintura). }\end{array}$} \\
\hline \multicolumn{5}{|c|}{$\begin{array}{l}\text { admitir uma classe de agressividade mais branda (uma classe acima) em obras em regiões } \\
\text { seco, com umidade média relativa do ar menor ou igual a } 65 \% \text {, partes da estrutura protegidas } \\
\text { em ambientes predominantemente secos ou regiões onde raramente chove. }\end{array}$} \\
\hline c & \multicolumn{4}{|c|}{$\begin{array}{l}\text { Ambientes quimicamente agressivos, tanques industriais, galvanoplastia, branqueamento em indús- } \\
\text { trias de celulose e papel, armazéns de fertilizantes, indústrias químicas. }\end{array}$} \\
\hline
\end{tabular}

Fonte: ABNT NBR 6118:2014.

Não somente a agressividade do meio, mas também as características do concreto e a espessura do cobrimento da armadura interferem na durabilidade das estruturas. Nesse âmbito, tem-se necessário a normatização relacionando a classe de agressividade com relação água/cimento em massa, tipo de cimento e cobrimento da armadura conforme a estrutura e o elemento estrutural (Tabela $4.3 \mathrm{e}$ 4.4)

Tabela 4.3 - Correspondência entre a classe de agressividade e a qualidade do concreto

\begin{tabular}{|c|c|c|c|c|c|}
\hline \multirow{2}{*}{ Concreto $^{a}$} & \multirow{2}{*}{ Tipo b, c } & \multicolumn{4}{|c|}{ Classe de agressividade } \\
\hline & & I & II & III & IV \\
\hline \multirow{2}{*}{$\begin{array}{c}\text { Relação } \\
\text { água/cimento em } \\
\text { massa }\end{array}$} & $\mathrm{CA}$ & $\leq 0,65$ & $\leq 0,60$ & $\leq 0,55$ & $\leq 0,45$ \\
\hline & $\mathrm{CP}$ & $\leq 0,60$ & $\leq 0,55$ & $\leq 0,50$ & $\leq 0,45$ \\
\hline \multirow{2}{*}{$\begin{array}{l}\text { Classe de concreto } \\
\text { (ABNT NBR 8953) }\end{array}$} & CA & $\geq \mathrm{C} 20$ & $\geq \mathrm{C} 25$ & $\geq \mathrm{C} 30$ & $\geq \mathrm{C} 40$ \\
\hline & $\mathrm{CP}$ & $\geq \mathrm{C} 25$ & $\geq \mathrm{C} 30$ & $\geq \mathrm{C} 35$ & $\geq \mathrm{C} 40$ \\
\hline \multicolumn{6}{|c|}{$\begin{array}{l}\text { a concreto empregado na execução das estruturas deve cumprir com os requisitos estabelecidos na } \\
\text { b ABNT NBR } 12655 \text {. } \\
\text { b CA corresponde a componentes e elementos estruturais de concreto armado. } \\
\text { c CP corresponde a componentes e elementos estruturais de concreto protendido. }\end{array}$} \\
\hline
\end{tabular}

Fonte: ABNT NBR 6118:2014. 
Tabela 4.4 - Correspondência entre a classe de agressividade ambiental e o cobrimento nominal com tolerância de $10 \mathrm{~mm}$

\begin{tabular}{|c|c|c|c|c|c|c|}
\hline \multirow{3}{*}{\multicolumn{2}{|c|}{ Tipo de estrutura }} & \multirow{3}{*}{$\begin{array}{l}\text { Componente ou } \\
\text { elemento }\end{array}$} & \multicolumn{4}{|c|}{ Classe de agressividade ambiental } \\
\hline & & & I & II & III & IV c \\
\hline & & & \multicolumn{4}{|c|}{$\begin{array}{l}\text { Cobrimento nominal } \\
\qquad \mathrm{mm}\end{array}$} \\
\hline \multirow{3}{*}{\multicolumn{2}{|c|}{ Concreto armado }} & Laje $^{b}$ & 20 & 25 & 35 & 45 \\
\hline & & Viga/pilar & 25 & 30 & 40 & 50 \\
\hline & & $\begin{array}{l}\text { Elementos } \\
\text { estruturais em } \\
\text { contato com o solo d }\end{array}$ & \multicolumn{2}{|c|}{30} & 40 & 50 \\
\hline \multirow{2}{*}{\multicolumn{2}{|c|}{$\begin{array}{l}\text { Concreto } \\
\text { protendido a }\end{array}$}} & Laje & 25 & 30 & 40 & 50 \\
\hline & & Viga/pilar & 30 & 35 & 45 & 55 \\
\hline \multicolumn{7}{|c|}{$\begin{array}{l}\text { Cobrimento nominal da bainha ou dos fios, cabos e cordoalhas. O cobrimento da armadura passiva deve } \\
\text { respeitar os cobrimentos para concreto armado. }\end{array}$} \\
\hline \multicolumn{7}{|c|}{$\begin{array}{l}\text { Para a face superior de lajes e vigas que serão revestidas com argamassa de contrapiso, com revestimentos } \\
\text { finais secos tipo carpete e madeira, com argamassa de revestimento e acabamento, como pisos de } \\
\text { elevado desempenho, pisos cerâmicos, pisos asfálticos e outros, as exigências desta Tabela podem ser } \\
\text { substituídas pelas de } 7.4 .7 .5 \text {, respeitado um cobrimento nominal } \geq 15 \mathrm{~mm} \text {. }\end{array}$} \\
\hline \multicolumn{7}{|c|}{$\begin{array}{l}\text { c Nas superfícies expostas a ambientes agressivos, como reservatórios, estações de tratamento de água e } \\
\text { esgoto, condutos de esgoto, canaletas de efluentes e outras obras em ambientes química e intensamente } \\
\text { agressivos, devem ser atendidos os cobrimentos da classe de agressividade IV. }\end{array}$} \\
\hline \multicolumn{7}{|c|}{$\begin{array}{l}\text { d No trecho dos pilares em contato com o solo junto aos elementos de fundação, a armadura deve ter } \\
\text { cobrimento nominal } \geq 45 \mathrm{~mm} \text {. }\end{array}$} \\
\hline
\end{tabular}

Fonte: ABNT NBR 6118:2014.

\subsection{MÉTODOS NÃO DESTRUTIVOS}

\subsubsection{MEDIDA DE CARBORNATAÇÃO}

As técnicas de laboratório que podem ser utilizadas para a determinação da profundidade de carbonatação são a análise química (aspersor ou lápis medidor de $\mathrm{pH})$, a difração de raio $X$, a espectroscopia de infravermelho e a análise termogravimétrica (Neville, 2016). O método mais usual, simples, rápido e com custo baixo é o químico com o aspersor, o qual utiliza-se a solução de fenolftaleína diluída em álcool.

O ensaio consiste em analisar uma parte da superfície, recentemente exposta (fraturada) do concreto até o aço, aplicar a solução a base de fenolftaleína, que irá indicar através da coloração da solução se existe a presença de carbonatação. A fenolftaleína mantém-se incolor em soluções ácidas e torna-se rocha em soluções 
básicas, ou seja, quando o concreto está carbonatado a coloração é incolor e quando a estrutura não está carbonatada a solução é rocha (Figura 4.3), é preciso salientar que esse método somente indica a presença de hidróxido de cálcio, $\mathrm{Ca}(\mathrm{OH})_{2}$, e não a ausência total de carbonatação. Em seguida, mede-se a distância da frente de carbonatação através do paquímetro e calcula-se o grau de carbonatação.

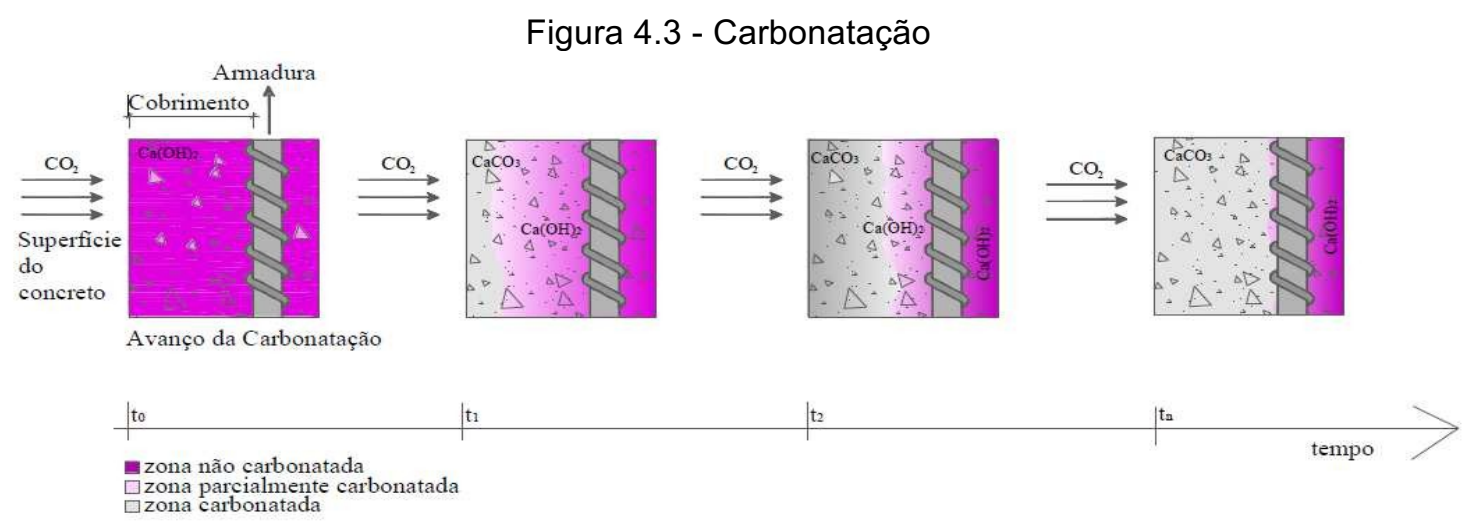

Fonte: Possan, 2010

O cálculo para velocidade de carbonatação é feita pela seguinte fórmula:

$$
\mathrm{X}_{\mathrm{CO}_{2}}=K_{\mathrm{CO}_{2}} \cdot \sqrt{t}
$$

Onde:

$\mathrm{X}_{\mathrm{CO} 2:}$ profundidade de carbonatação $(\mathrm{mm})$;

$\mathrm{K}_{\mathrm{CO} 2}$ : constante de carbonatação $\left(\mathrm{mm} . \mathrm{ano}^{-0,5}\right)$;

t: tempo em anos;

$\mathrm{Na}$ Tabela 4.5 tem-se vantagens e desvantagens do método da fenolftaleína.

Tabela 4.5 - Vantagens e desvantagens da utilização do método de aspersão de fenolftaleína

\begin{tabular}{|l|l|}
\hline \multicolumn{1}{|c|}{ VANTAGENS } & \multicolumn{1}{c|}{ DESVANTAGENS } \\
\hline $\begin{array}{l}\text { Equipamento leve, simples de operar e } \\
\text { custo baixo; }\end{array}$ & Resultados não são precisos; \\
\hline Causa danos na superfície; & $\begin{array}{l}\text { Não quantifica o nível de carbonatação; } \\
\text { Indica a presença de hidróxido de cálcio, } \\
\mathrm{Ca}(\mathrm{OH})_{2}, \quad \text { e não a ausência total de } \\
\text { carbonatação; }\end{array}$ \\
\hline & $\begin{array}{l}\text { Fratura o elemento estrutural (ensaio } \\
\text { destrutivo). }\end{array}$ \\
\hline
\end{tabular}




\subsubsection{AVALIAÇÃO DA FRENTE DE CLORETO}

Vários são os métodos que podem ser utilizados para realizar a análise quantitativa de cloretos nas amostras, tais como: análise por fluorescência de raiosx, método eletrodo de íon seletivo, método de Volhar, ASTM C 102 Test Method for Electrical Indication of Concrete's Ability to Resist Chloride Ion Penetration, método químico. (Monteiro, 2002; Figueiredo, 2005).

A avaliação da frente de cloretos é comumente determinada pelo método químico, por ser um ensaio rápido e prático. É realizado a partir da aspersão de indicador à base de nitrato de prata que ao reagir com os cloretos presentes no concreto forma um composto esbranquiçado/prateado, decorrente da precipitação de cloreto de prata, contrastando assim com a zona não atacada, de coloração mais escura (Figura 4.4), o que permite mensurar a profundidade da frente de cloretos no concreto (Cachim, Carasek, Cascudo, Figueiredo, Santos, Velosa, 2014).

Figura 4.4 - Avaliação da frente de cloreto por aspersão de indicador à base de nitrato de prata

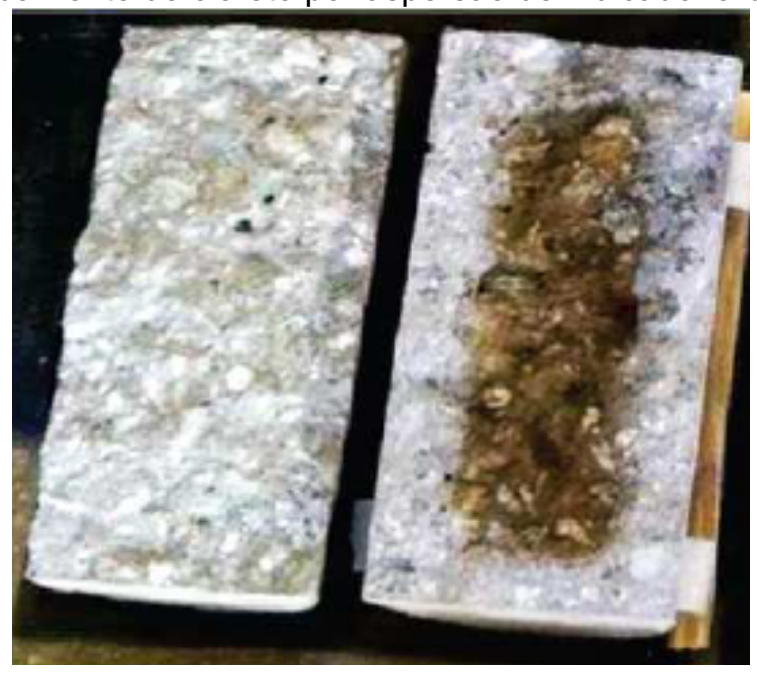

Fonte: IBRACON, 2014

De acordo com a análise do método de aspersão de indicador à base de nitrato de prata, realizou-se uma tabela comparativa mostrando as vantagens e desvantagens da utilização desse método (Tabela 4.6). 
Tabela 4.6 - Vantagens e desvantagens do método de aspersão de indicador à base de nitrato de prata

\begin{tabular}{|l|l|}
\hline \multicolumn{1}{|c|}{ VANTAGENS } & \multicolumn{1}{c|}{ DESVANTAGENS } \\
\hline $\begin{array}{l}\text { Aspersor é um equipamento leve, } \\
\text { simples de operar e custo baixo; }\end{array}$ & Resultados não são precisos; \\
\hline Causa danos na superfície; & $\begin{array}{l}\text { Não quantifica a quantidade de } \\
\text { cloreto; }\end{array}$ \\
\hline Indica a presença ou não de cloreto & $\begin{array}{l}\text { Fratura do elemento estrutural } \\
\text { (ensaio destrutivo); }\end{array}$ \\
\hline
\end{tabular}

\subsubsection{DETECÇÃO ELETROMAGNÉTICA DA ARMADURA}

O ensaio de detecção eletromagnética da armadura utiliza-se o pacômetro como equipamento e é usado para localizar as barras de aço e estimar a espessura do cobrimento de concreto. Essa ação ocorre devido o aço interagir com ondas eletromagnéticas de baixa frequência.

Segundo Mehta e Monteiro (2014), existem dois principais pacômetros, o primeiro usa uma bobina para gerar um fluxo magnético, o qual é medida sua intensidade por uma bobina sensora. E o segundo, localiza a barra de aço por varredura da superfície do concreto com uma bobina elétrica fixada a uma fonte CA e um indicador de corrente (Figura 4.5).

Figura 4.5 - Pacômetro por varredura

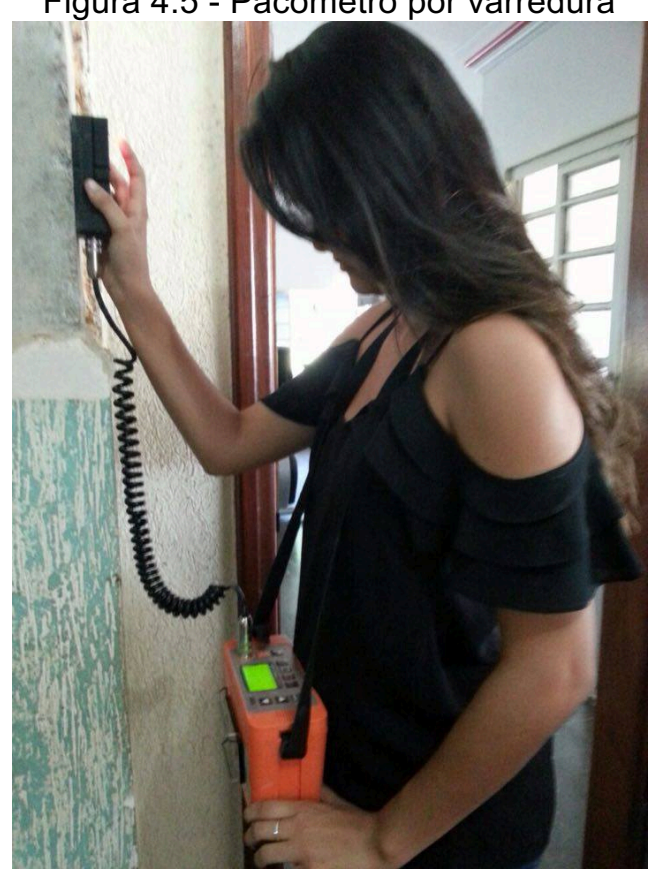

Fonte: Ensaio executado pela autora no $1^{\circ} \mathrm{GBM}$ no dia 06 de Abril de 2016. 
Para a identificação das barras, convém que a área a estudar seja limpa, de forma a retirar o máximo possível de impurezas. Depois de ligado, o pacômetro deve ser calibrado para haver uma maior precisão. Nessa perspectiva, é necessário fraturar uma parte do cobrimento até o aço de um dos elementos estruturais da edificação, de modo que, ao passar o sensor em um local próximo a fratura, sempre no mesmo sentido (vertical ou horizontal), verifica se o tamanho da bitola indicado no aparelho confere com o da estrutura, assim como, se a localização da armadura está de acordo com a identificada pelo sensor.

Após a calibração e a obtenção do diâmetro do aço, dá-se início ao processo de varrimento. $\mathrm{O}$ varrimento deve ser feito com a face sensível da sonda virada para o elemento em estudo, analisando sempre em uma direção (vertical ou horizontal) e onde não há encontro de barras. Assim que estiver na presença de elementos metálicos, o aparelho irá emitir um som que se torna mais alto e agudo, à medida que aumenta a proximidade entre estes e a sonda. Ao mesmo tempo, o visor do pacômetro mostrará também valores de recobrimento que quanto menores forem, mais próximos estão dos elementos metálicos. Podemos ainda utilizar o aparelho em modo silencioso, guiando-nos apenas pelos valores que nos são dados pelo monitor. Assim que obtiver o resultado sonoro mais agudo ou o valor de recobrimento mais baixo, significa que o eixo longitudinal da sonda está paralelamente alinhado com a orientação da barra. Após a correta identificação da barra, deve-se, com o auxílio de giz ou outra ferramenta adequada, marca-lo a face em estudo. Este procedimento deverá ser repetido até termos a delineação completa da armadura.

Para uma melhor performance em termos de resultados, deve-se delinear em primeiro lugar, os aços que se encontram com menos recobrimento e só depois as suas perpendiculares. Para uma correta delineação destes últimos, deve-se fazer o varrimento nos intervalos dos aços já identificados.

Segundo a análise do método de detecção eletromagnética da armadura, elaborou-se uma tabela comparativa mostrando as vantagens e desvantagens da utilização desse método (Tabela 4.7). 
Tabela 4.7 - Vantagens e desvantagens do método de detecção eletromagnética da armadura

\begin{tabular}{|l|l|}
\hline \multicolumn{1}{|c|}{ VANTAGENS } & \multicolumn{1}{|c|}{ DESVANTAGENS } \\
\hline $\begin{array}{l}\text { Equipamento leve, simples de operar } \\
\text { e custo alto; }\end{array}$ & $\begin{array}{l}\text { Os resultados alcançam somente a } \\
\text { zona superficial do concreto; }\end{array}$ \\
\hline $\begin{array}{l}\text { Não causa grandes danos na } \\
\text { superfície; }\end{array}$ & Resultados não são precisos; \\
\hline Estima cobrimento e bitola; & $\begin{array}{l}\text { Resulta em erro quando há } \\
\text { concentração de barras de aço; }\end{array}$ \\
\hline & $\begin{array}{l}\text { Fratura de um elemento estrutura da } \\
\text { edificação para conferir a calibração } \\
\text { do equipamento. }\end{array}$ \\
\hline
\end{tabular}

\subsubsection{DUREZA SUPERFICIAL}

O método é executado através de um esclerômetro de reflexão de Schmidt, o qual obtém um valor numérico através de um impacto do aparelho sobre uma superfície de concreto. $\mathrm{O}$ esclerômetro consiste em um martelo controlado por uma mola que transmite uma carga ao êmbolo (Figura 4.6). Segundo Mehta e Monteiro (2014), o martelo ocasiona um impacto sobre o êmbolo, e a massa controlada pela mola sofre um recuo, reflexão ou rebote após o choque, gerando um valor numérico para a reflexão do martelo. Esse número, chama-se índice esclerométrico ou índice de reflexão.

Figura 4.6 - Ilustração da sequência de execução do ensaio de esclerometria

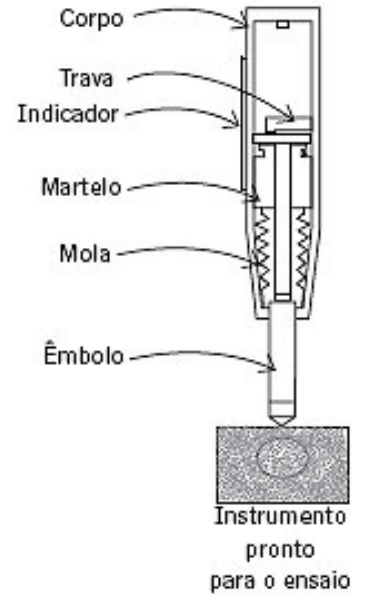

(a)

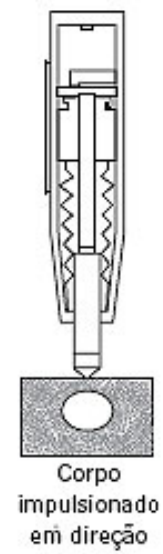

ao objeto de ensaio

(b)

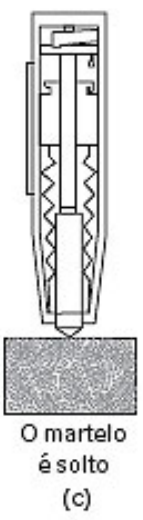

(c)

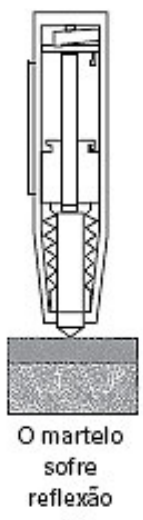

(d)

Fonte: Mehta \& Monteiro, 2008. 
Figura 4.7 - Ensaio de esclerometria

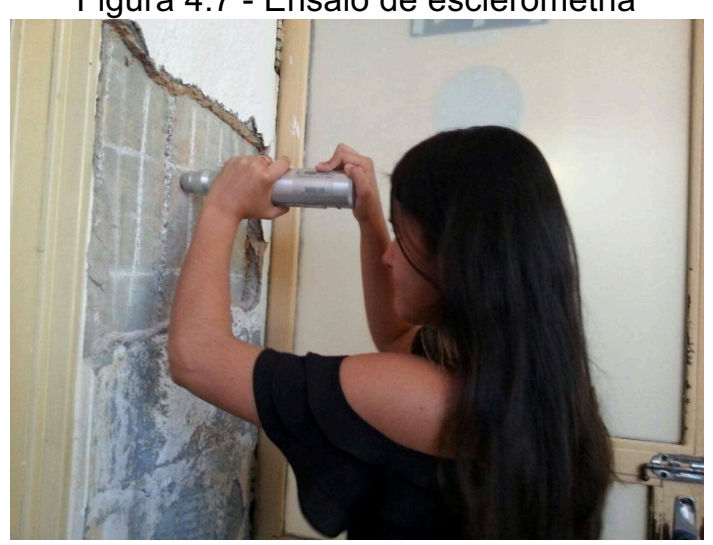

Fonte: Ensaio executado pela autora no 1․ GBM no dia 06 de Abril de 2016.

Para execução do ensaio inicialmente faz-se a localização das ferragens com o pacômetro, e em seguida, são lixadas com pedra de carborundum a fim de retirar a camada de impurezas, umidade atmosférica e possíveis imperfeições na superfície do concreto. A pedra é pressionada contra a superfície do concreto em movimentos circulares até se obter uma superfície homogênea e suficientemente plana para a execução do ensaio. A divisão do espaçamento entre as ferragens tem que haver uma distância mínima entre os dois centros de impacto de 30 milímetros e a realização de no mínimo 9 e no máximo 16 impactos, conforme a norma ABNT NBR 7584:2012 (Figura 4.7).

Para o cálculo do índice esclerométrico, utiliza-se a média dos impactos realizados em uma área de ensaio e desprezam-se os índices esclerométricos (IE) afastados mais do que $10 \%$ da média, logo obtém-se a dureza superficial do concreto em análise. O IE final deve ser obtido com no mínimo 5 valores individuais e não é considerado quando o IE menor que 20.

Coeficiente de correção do índice esclerométrico é obtido pela Equação 4.3:

$$
\mathrm{k}=\mathrm{n} \frac{\text { IEnom }}{\sum_{\mathrm{i}=0}^{\mathrm{n}} \mathrm{IEi}}
$$

Onde:

k: coeficiente de correção do índice esclerométrico

$\mathrm{n}$ : número de impactos

IE nom: índice esclerométrico nominal na bigorna de aço, fornecido pelo fabricante; IE: índice esclerométrico obtido em cada impacto do esclerômetro na bigorna de aço. 
Obtenção do índice esclerométrico médio efetivo de cada área de ensaio, usando a Equação 4.4:

$$
I E e=k x I E
$$

Onde:

IEe: Índice esclerométrico médio efetivo;

k: Coeficiente de correção do índice esclerométrico, obtido quando da aferição do aparelho;

IE : Î́ndice esclerométrico médio;

A partir da medição da distância de retorno do pistão obtida no ensaio com o martelo de Schimidt é possível, através de correlações existentes, avaliar a resistência à compressão do concreto baseado em curvas de calibração (Menegetti, 2009).

Evangelista (2002) afima que geralmente os fabricantes dos equipamentos para estes ensaios fornecem estas curvas, porém estas são desenvolvidas usando materiais disponíveis no país deste fabricante, e, ao serem empregadas numa localidade onde há outros tipos de materiais, a resistência pode ser avaliada com erros consideráveis.

De acordo com a norma ABNT NBR 7584: 2012, o ensaio de esclerometria pode ser influenciado pelos seguintes parâmetros:

a) Agregado empregado;

O tipo e a quantidade de agregado desempenham um papel preponderante no resultado, ele se torna um fator crítico se o objetivo for obter uma correlação entre o índice esclerométrico e resistência.

b) Condição da superfície de ensaio;

Superfícies irregulares, ásperas, curvas ou talhadas não fornecem resultados homogêneos.

c) Condição de umidade;

Uma superfície umidade produz um índice esclerométrico mais baixo do que uma superfície seca.

d) Carbonatação superficial; 
A carbonatação do concreto produz o carbonato de cálcio, o qual é um composto rígido que interfere no índice esclerométrico.

e) Direção do esclerômetro, conforme sua posição horizontal, vertical ou inclinado;

O ensaio é realizado perpendicular a uma superfície, devido à força da gravidade, o índice esclerométrico diferencia conforme a posição.

f) Esbeltez da peça estrutural;

Devem ter dimensões superiores a 100 milímetros na direção do impacto, para serem suficientemente rígidos e evitarem a interferência de fenômenos de ressonância, vibração e dissipação de energia no resultado.

g) Localização do êmbolo;

Se o êmbolo for colocado sobre um agregado, o índice esclerométrico será incorretamente elevado. Caso o êmbolo for colocado sobre um vazio, resultará em um índice esclerométrico menor.

h) Operador do equipamento;

O ensaio consiste em uma força externa pressionar o êmbolo sobre a superfície. Caso tenha mais de um operador, a força externa diverge, ocasionando diferentes resultados.

Conforme a análise do método de dureza superficial, elaborou-se uma tabela comparativa mostrando as vantagens e desvantagens da utilização desse método (Tabela 4.8).

Tabela 4.8 - Vantagens e desvantagens do método de dureza superficial

\begin{tabular}{|l|l|}
\hline \multicolumn{1}{|c|}{ VANTAGENS } & \multicolumn{1}{c|}{ DESVANTAGENS } \\
\hline $\begin{array}{l}\text { Equipamento leve, simples de operar } \\
\text { e acessivo; }\end{array}$ & $\begin{array}{l}\text { Os resultados alcançam somente a } \\
\text { zona superficial do concreto } \\
\text { aproximadamente } 30 \mathrm{~mm} \text { a } 50 \mathrm{~mm} ;\end{array}$ \\
\hline $\begin{array}{l}\text { Danos causados na superfície } \\
\text { praticamente nulos; }\end{array}$ & $\begin{array}{l}\text { Se o concreto estiver carbonatado, } \\
\text { altera os resultados, obtendo índices } \\
\text { elevados; }\end{array}$ \\
\hline Avalia a uniformidade do concreto; & $\begin{array}{l}\text { Não resulta em dados precisos para } \\
\text { de resistência do concreto }\end{array}$ \\
\hline $\begin{array}{l}\text { Monitoramento do desenvolvimento } \\
\text { da resistência ao logo do tempo; }\end{array}$ & $\begin{array}{l}\text { É necessário a combinação de } \\
\text { outros métodos destrutivos e não } \\
\text { destrutivos para uma melhor analise; }\end{array}$ \\
\hline Estima a resistência do concreto. & \\
\hline
\end{tabular}




\subsubsection{VELOCIDADE DE PULSO ULTRASSÔNICO}

Conforme a norma ABNT NBR 8802:2013, o método consiste em medir o tempo de percurso das ondas longitudinais de pulso ultrassônico passando através do concreto. Tem como principais funções:

a) Verificar a homogeneidade do concreto através de parâmetros estatísticos, como desvio padrão ou coeficiente de variação dos dados de velocidade de propagação da onda ultrassônica;

b) Detectar eventuais imperfeições, falhas internas, profundidade das fissuras do concreto.

c) Monitorar variações do concreto decorrentes de ataques químicos.

A realização do ensaio decorre, primeiramente da calibragem do aparelho, por meio de uma barra padrão o qual tem o tempo de percurso catalogado para verificar se o aparelho indica o mesmo tempo de percurso do que o bloco. Em seguida, verificar se a superfície de ensaio está devidamente lisa e isenta de sujeiras e aplicar uma fina camada de acoplante (vaselina, graxa de silicone ou de mineral) nas faces dos transdutores ou na superfície de ensaio, segundo Metha e Monteiro (2014). Posicionar os transdutores com os seguintes arranjos (Figura 4.8):

a) Transmissão direta: transdutores nas faces opostas do material;

b) Transmissão semidireta: transdutores nas faces adjacentes;

c) Transmissão indireta: transdutores na mesma face;

Figura 4.8 - Tipos de Transmissão

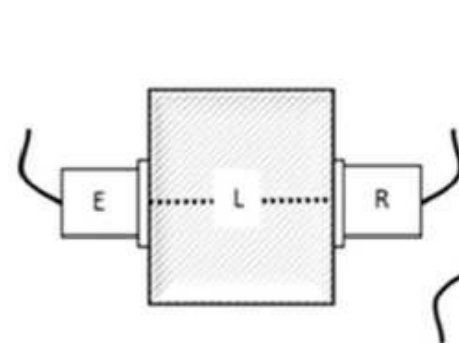

A

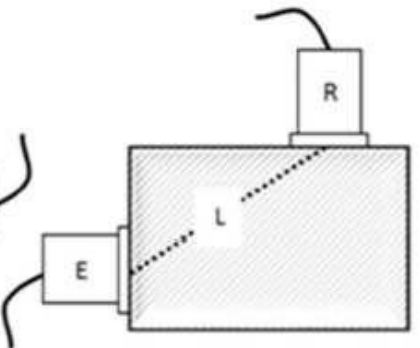

B

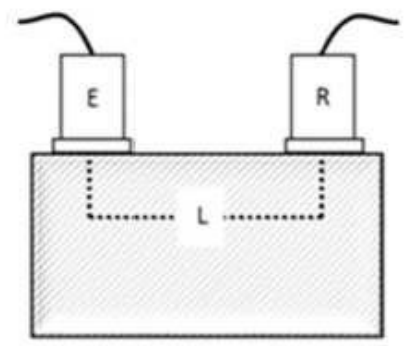

C

(A) transmissão direta, (B) transmissão semidireta, (C) transmissão indireta, (E) representa o transdutor emissor, $(R)$ representa o transdutor receptor e $(L)$ é a distância entre transdutores. 
Obtém-se a velocidade de propagação de onda conforme a seguinte fórmula:

$$
V=\frac{L}{t}
$$

Onde:

V: velocidade de propagação da onda $(\mathrm{m} / \mathrm{s})$;

$L:$ distância entre os transdutores $(m)$;

t: tempo de propagação da onda (s);

O módulo de deformação dinâmico do concreto é estimado pela seguinte fórmula:

$$
E_{D}=V^{2} \cdot Q \cdot \frac{(1+n) \cdot(1-2 n)}{1-n}
$$

Onde:

$\mathrm{V}$ : velocidade de propagação $(\mathrm{km} / \mathrm{s})$;

Q: massa específica do concreto $\left(\mathrm{kg} / \mathrm{m}^{3}\right)$;

$\mathrm{n}$ : coeficiente de Poisson (concreto de alta resistência é igual a 0,15 e concreto de baixa resistência, igual a 0,3);

$E_{\mathrm{D}}$ : módulo de elasticidade dinâmico (MPa);

Profundidade da fissura é embasada pela seguinte fórmula:

$$
h=x \cdot \sqrt{\frac{t c^{2}}{t s^{2}}-1}
$$

Onde:

X: metade da distância entre os sensores;

h: profundidade da fissura (mesma unidade de medida do $\mathrm{x}$ );

tc: tempo de propagação da onda na região fissurada ( $\mu s)$;

ts: tempo de propagação da onda no mesmo concreto sem falhas ( $\mu \mathrm{s})$;

Os resultados são influenciados pelos seguintes fatores: 
a) Grau de hidratação;

Conforme é feita a hidratação do concreto, a porosidade diminui e o meio se torna mais compacto, tendo a propagação da onda mais rápido devido o meio ser mais sólido.

b) Condições de umidade;

A velocidade da onda aumenta em meios saturados, conforme a $\mathrm{ACl}$ 228 (1989) apud Dias, Ferreira e Silva (2013), a velocidade de pulso através do concreto saturado pode ser $5 \%$ mais alta do que no mesmo concreto na condição seca ao ar, embora esta influência seja menor para concretos de alta resistência do que para os de baixa resistência.

c) Quantidade e tipo de agregado;

Os agregados possuem velocidades de onda mais altas do que a pasta de cimento. Dessa forma, aumentando a quantidade de agregado, aumenta também a velocidade de propagação da onda;

d) Microfissuração;

As microfissuras reduzem os módulos de elasticidade do concreto e, consequentemente, reduzem a velocidade da onda em seu interior.

e) Presença de armadura;

A armadura aumenta a velocidade de onda aparente do concreto, o qual deve ser evitada a sua presença para uma melhor análise de dados.

f) Distância entre tradutores;

A norma EN-ISO 8047 (1994) prescreve a necessidade de se manter distâncias mínimas entre os transdutores, com o intuito de se evitar erros nas leituras, sendo: $100 \mathrm{~mm}$ para concretos com agregados de dimensão máxima igual a $20 \mathrm{~mm}$; de $150 \mathrm{~mm}$ para concretos com agregados de dimensão máxima entre $20 \mathrm{~mm}$ e $40 \mathrm{~mm}$. (Dias, Ferreira e Silva (2013), p. 105)

De acordo com a norma BS EN 12504-4:2000, relaciona a velocidade de propagação com a qualidade do concreto conforme a tabela 4.9.

Tabela 4.9 - Relação entre velocidade de propagação e a qualidade do concreto

\begin{tabular}{|c|c|}
\hline Velocidade longitudinal da onda $\mathbf{e m}(\mathbf{K m} / \mathbf{s})$ & Qualidade do concreto \\
\hline $\mathrm{v}<2$ & Muito fraca \\
\hline $2<\mathrm{v}<3$ & Fraca \\
\hline $3<\mathrm{v}<3,5$ & Média \\
\hline $3,5<\mathrm{v}<4$ & Boa \\
\hline $4<\mathrm{v}<4,5$ & Muito boa \\
\hline $\mathrm{v}>4,5$ & Excelente \\
\hline
\end{tabular}


Fonte: BS EN 12504-4:2000.

De acordo com a análise do método de pulso ultrassônico, elaborou-se uma tabela comparativa mostrando as vantagens e desvantagens da utilização desse método (Tabela 4.10).

Tabela 4.10 - Vantagens e desvantagens do método de pulso ultrassônico

\begin{tabular}{|l|l|}
\hline \multicolumn{1}{|c|}{ VANTAGENS } & \multicolumn{1}{|c|}{ DESVANTAGENS } \\
\hline $\begin{array}{l}\text { Equipamento leve, simples de operar } \\
\text { e custo médio; }\end{array}$ & $\begin{array}{l}\text { A correlação entre a velocidade da } \\
\text { onda e resistência poderá ser mal } \\
\text { interpretada se existirem } \\
\text { descontinuidades no elemento; }\end{array}$ \\
\hline Causa nenhum dano na superfície; & $\begin{array}{l}\text { Tem como ponto crítico a boa } \\
\text { ligação entre transdutores e } \\
\text { concreto; }\end{array}$ \\
\hline $\begin{array}{l}\text { Avalia o concreto em toda espessura } \\
\text { do elemento estrutural }\end{array}$ & $\begin{array}{l}\text { Difícil a interpretação de dados } \\
\text { isoladamente; }\end{array}$ \\
\hline $\begin{array}{l}\text { Verificar a homogeneidade do concreto } \\
\text { através de parâmetros estatísticos; }\end{array}$ & \\
\hline $\begin{array}{l}\text { Detecção de eventuais imperfeições; } \\
\text { Monitoramento de variações do } \\
\text { concreto decorrentes de ataques } \\
\text { químicos; }\end{array}$ & \\
\hline \begin{tabular}{l} 
Estima resistência à compressão; \\
\hline
\end{tabular} & \\
\hline
\end{tabular}

\subsection{MÉTODO SEMI-DESTRUTIVO}

\subsubsection{EXTRAÇÃO DO TESTEMUNHO E RESISTÊNCIA A COMPRESSÃO EM CORPO DE PROVA DE CONCRETO}

O ensaio é respaldado pela ABNT NBR 7680-1:2015 e tem como objetivo a verificação da segurança estrutural, obtendo assim a resistência mecânica, módulo de deformação, absorção capilar, permeabilidade do concreto.

Dessa forma, a extração de testemunho pode ser utilizada para (ABNT NBR 7680-1:2015):

a) Para aceitação definitiva do concreto, em casos de não conformidade da resistência à compressão do concreto com os critérios da ABNT NBR 12655:2015; 
b) Para avaliação da segurança estrutural de obras em andamento, nos casos de não conformidade da resistência à compressão do concreto com os critérios da ABNT NBR 12655:2015;

c) Para verificação da segurança estrutural em obras existentes, tendo em vista a execução de obras de retrofit, reforma, mudança de uso, incêndio, acidentes, colapsos parciais e outras situações em que a resistência à compressão do concreto deva ser conhecida.

De acordo com a ABNT NBR 7680-1:2015, o equipamento utilizado para a realização deve permitir a obtenção de amostras não alteradas do concreto da estrutura. O aparelho empregado possui uma broca ou uma sonda rotativa, decorrida de coroa de diamantes ou material abrasivo (Figura 4.9), e o corte deve ser feito na presença de água.

Figura 4.9 - Equipamento de extração de testemunhos de concreto

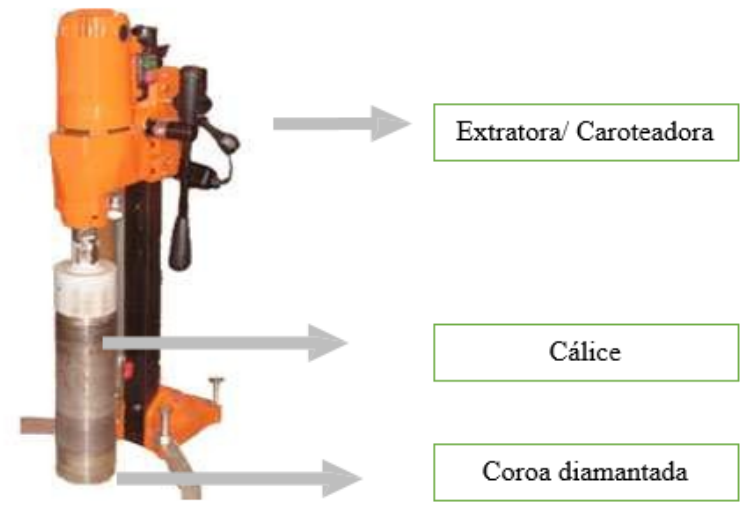

Fonte: Felipe C. Bungenstab, 2015.

Seguindo as condições da ABNT NBR 7680 - 1:2015, o local de extração deve ser determinado em consenso entre o tecnologista de concreto, construtor e projetista. No caso de estruturas sem histórico do controle tecnológico, estas devem ser divididas em lotes, identificados em função da importância dos elementos estruturais que as compõem e da homogeneidade do concreto, que deve ser avaliada e mapeadas por meio de ensaios não destrutivos. Pode ser utilizado qualquer procedimento confiável, sendo adequado empregar a avaliação da dureza superficial pelo esclerômetro de reflexão (ABNT NBR 7584:2012) ou a determinação da velocidade de propagação de onda ultrassônica (ABNT NBR 8802:2013).

Na norma estabelece a extração do menor número possível de testemunhos de cada componente estrutural em estudo, sendo locais próximos ao centro do elemento estrutural e não conter barras de aço, caso ocorra, serão aceitos barras de 
aço em direção ortogonal, desde que tenham diâmetro nominal máximo de $10 \mathrm{~mm}$. O diâmetro dos corpos de prova deve ser no mínimo três vezes o tamanho máximo do agregado graúdo e preferencialmente maior ou igual a 100 milímetros, para se obter um material homogêneo e para que a influência da extração não seja grande. Quanto maior for o diâmetro do corpo de prova, mais próximo será o resultado obtido com o da resistência à compressão real do concreto.

Devem ser determinados a massa específica aparente dos testemunhos e suas bases devem ser regularizadas por retífica ou por capeamento, conforme a ABNT NBR 5738:2016.

A fórmula para obter a resistência à compressão axial diretamente dos testemunhos extraídos é o seguinte:

$$
f_{\text {ci,ext, inicial }}=\frac{4 F}{\pi \cdot D^{2}}
$$

Onde:

$f_{\text {ci,ext,inicial: }}$ resistência à compressão axial obtida diretamente dos testemunhos extraídos e ensaiados (MPa);

F: força máxima alcançada em Newton (N);

D: diâmetro do corpo de prova em milímetros (mm).

Logo, é preciso acrescentar coeficiente de correção para que o resultado chegue ao mais próximo ao real. O cálculo é realizado a partir da seguinte equação:

$$
f_{c i, e x t}=\left[1+(k 1+k 2+k 3+k 4] x f_{\text {ci,ext,inicial }}\right.
$$

Onde:

$f_{c i \text { ext: }}$ resistência do concreto à compressão;

k1: correção devida à relação altura/diâmetro $(\mathrm{h} / \mathrm{d})$ do testemunho cilíndrico;

k2: correção devida ao efeito deletério do broqueamento em função do diâmetro do testemunho;

k3: correção devida à diferença na direção da extração com relação ao lançamento do concreto;

k4: correção devida ao efeito da umidade do testemunho (condição de sazonamento). 
Os coeficientes são determinados pela ABNT NBR 7680-1:2015 e aplicam-se aos resultados de testemunhos de estruturas de concreto de massa específica normal, compreendida no intervalo de $2000 \mathrm{~kg} / \mathrm{m}^{3}$ a $2800 \mathrm{~kg} / \mathrm{m}^{3}$, e fck menor ou igual a 100.

a) Coeficiente de correção devido à relação a h/d (k1)

A relação altura/diâmetro recomendada é 2, sendo admitida uma relação mínima de 1 , porém deve ser corrigida multiplicando o fator de correção, conforme a Tabela 4.1, permitindo a interpolação linear.

Tabela 4.11 - Coeficiente de correção em relação h/d (k1)

\begin{tabular}{|l|l|l|l|l|l|l|l|l|l|l|l|l|l|l|l|}
\hline $\boldsymbol{h} / \boldsymbol{d}$ & 2,00 & 1,88 & 1,75 & 1,63 & 1,50 & 1,42 & 1,33 & 1,25 & 1,21 & 1,18 & 1,14 & 1,11 & 1,07 & 1,04 & 1,00 \\
\hline $\boldsymbol{k}_{\mathbf{1}}$ & 0,00 & $-0,01$ & $-0,02$ & $-0,03$ & $-0,04$ & $-0,05$ & $-0,06$ & $-0,07$ & $-0,08$ & $-0,09$ & $-0,10$ & $-0,11$ & $-0,12$ & $-0,13$ & $-0,14$ \\
\hline
\end{tabular}

Fonte: ABNT NBR 7680-1: 2015

b) Coeficiente de correção devido ao efeito deletério do bronqueamento em função do diâmetro do testemunho (k2)

O processo de extração gera o que se denomina de "efeito de broqueamento", que ocorre em todos os casos de extração e é mais acentuado em testemunhos de menor diâmetro. Na Tabela 4.12, expressa os valores de correção para esse efeito, sendo permitido a interpolação linear dos coeficientes.

Tabela 4.12 - Coeficiente de correção do bronqueamento em função do diâmetro do testemunho (k2)

\begin{tabular}{|c|c|c|c|c|c|}
\hline $\begin{array}{c}\text { Diâmetro do testemunho }\left(\boldsymbol{d}_{\mathbf{t}}\right) \\
\mathrm{mm}\end{array}$ & $\leq 25$ & $50^{\mathrm{a}}$ & 75 & 100 & $\geq 150$ \\
\hline $\boldsymbol{k}_{2}$ & $\begin{array}{c}\text { Não } \\
\text { permitido }\end{array}$ & 0,12 & 0,09 & 0,06 & 0,04 \\
\hline
\end{tabular}

a Neste caso, o número de testemunhos deve ser o dobro daquele estabelecido na Tabela 1.

Fonte: ABNT NBR 7680-1: 2015

c) Coeficiente de correção devido a direção da extração em relação ao lançamento do concreto $(\mathrm{k} 3)$

As extrações devem ser feitas, sempre que possível, no sentido do lançamento do concreto (como em laje), pois o sentido da carga da estrutura será a mesma ao do ensaio, tendo assim uma maior correlação com estrutura ensaiada e resultando no coeficiente nulo. Já extrações realizadas no sentido perpendicular ao lançamento (como pilares, cortinas e paredes moldados no local), o coeficiente é 0,05 .

d) Coeficiente de correção devido ao efeito de umidade do testemunho (k4) 
Os testemunhos devem ser mantidos no laboratório conforme a região da estrutura a ser analisada. Se o local de extração estiver em contado com a água, o corpo de prova deverá ficar em tanques de cura ou câmera úmida pelo período de $72 \mathrm{~h}$, e o seu coeficiente é nulo. Já quando a área ensaiada é seca, o testemunho ficara exposto ao ar, em condições ambiente do laboratório por 72 h e o coeficiente é $-0,04$.

De acordo com ABNT NBR 7680-1:2015, para verificar a uniformidade dos resultados, necessita-se calcular a média aritmética com os resultados individuais corrigidos. Caso os resultados tenham divergência em relação à média maior do que $15 \%$, este valor deve ser analisado com mais rigor, pois pode indicar que o testemunho não faz parte do lote examinado.

A resistência de cálculo à compressão do concreto (fcd) a ser usada na verificação da estrutura deve ser calculada, utilizando-se a minoração de yc prevista na ABNT NBR 6118:2014 (Tabela 4.13), no caso de testemunhos extraídos da estrutura, dividir o valor de yc por 1,1 e o seu cálculo quando a verificação se faz em data j igual ou superior a 28 dias, utiliza-se a seguinte fórmula:

$$
f_{c d}=\frac{f_{c k}}{\gamma_{c}}
$$

Onde:

$\mathrm{f}_{\mathrm{cd}}=$ resistência de cálculo à compressão do concreto;

$\mathrm{f}_{\mathrm{ck}}=$ resistência característica à compressão do concreto;

$\mathrm{Y}_{\mathrm{c}}=$ coeficiente

Tabela 4.13 - Valores do coeficiente yc

\begin{tabular}{|c|c|}
\hline Combinações & Concreto \\
$\gamma_{\mathrm{c}}$ \\
\hline Normais & 1,4 \\
\hline Especiais ou de construção & 1,2 \\
\hline Excepcionais & 1,2 \\
\hline
\end{tabular}

Fonte: ABNT NBR 6118:2014

O fluxograma a seguir ilustra as etapas para obtenção dos resultados corrigidos a partir da ruptura dos testemunhos extraídos. 
Figura 4.10 - Fluxograma da análise dos resultados da extração

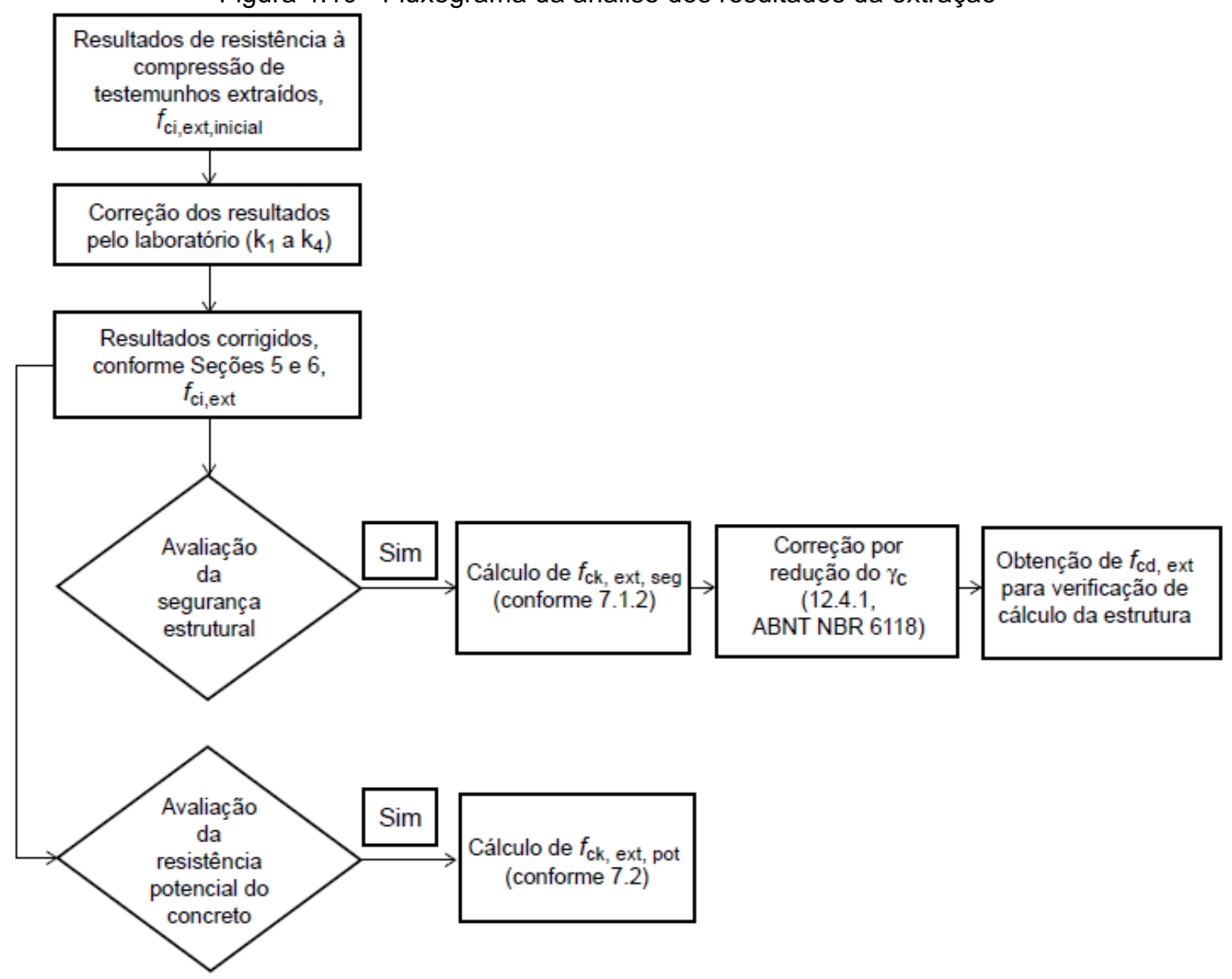

Fonte: ABNT NBR 7680-1:2015

Segundo a análise do método de resistência a compressão em testemunhos de concreto, elaborou-se a Tabela 4.14 de análise comparativa desse método.

Tabela 4.14 - Vantagens e desvantagens do método de resistência a compressão em testemunho de concreto

\begin{tabular}{|l|l|}
\hline \multicolumn{1}{|c|}{ VANTAGENS } & \multicolumn{1}{|c|}{ DESVANTAGENS } \\
\hline O serviço é acessivo; & $\begin{array}{l}\text { Interferência nos resultados de } \\
\text { compressão pelo efeito deletério do } \\
\text { bronqueamento; }\end{array}$ \\
\hline $\begin{array}{l}\text { Causa danos na superfície que } \\
\text { precisam ser reparados conforme a } \\
\text { norma; }\end{array}$ & $\begin{array}{l}\text { Interferência nos resultados de } \\
\text { compressão pelo tamanho do } \\
\text { testemunho; }\end{array}$ \\
\hline $\begin{array}{l}\text { Resulta em vários dados na estrutura, } \\
\text { como resistência mecânica, módulo de } \\
\text { deformação, absorção capilar, } \\
\text { permeabilidade do concreto; }\end{array}$ & $\begin{array}{l}\text { Resultados não são precisos devido a } \\
\text { qualidade dos testemunhos; }\end{array}$ \\
\hline $\begin{array}{l}\text { No testemunho extraído é possível } \\
\text { aplicar outros métodos não destrutivos; }\end{array}$ & $\begin{array}{l}\text { Avalia somente a parte do concreto } \\
\text { extraído. }\end{array}$ \\
\hline & $\begin{array}{l}\text { Equipamento de extração é pesado, } \\
\text { precisa de mão de obra qualificada e } \\
\text { custo do equipamento é caro. }\end{array}$ \\
\hline
\end{tabular}




\section{ESTUDO DE CASOS}

A pesquisa consiste nos métodos não destrutivos e semi-destrutivos realizados em duas edificações localizadas no Plano Piloto de Brasília-DF. Escolheu-se duas edificações uma pública e a outra privada, sendo a primeira para levantamento da estrutura (cobrimento, armação e resistência) e a outra para levantamento das causas de fissuras na edificação, conforme descritas a seguir.

\subsection{INSTITUIÇÃO PÚBLICA}

\subsubsection{LOCALIZAÇÃO E DESCRIÇÃO}

A primeira edificação estudada foi de uma instituição pública, localizado no Setor de Embaixadas, N1 Leste, Plano Piloto, Brasília-DF, que serviu como estudo de caso preliminar (Figura 5.1). Os ensaios foram coordenados pela equipe técnica da instituição, juntamente com os alunos das Turmas A e B do curso de Especialização em Projeto, Execução e Manutenção de Edificações do UniCEUB. A edificação possui pavimento térreo e superior, com academia, dormitório, secretária, garagem, banheiros e uma copa com sala de jogos.

Figura 5.1 - Instituição pública

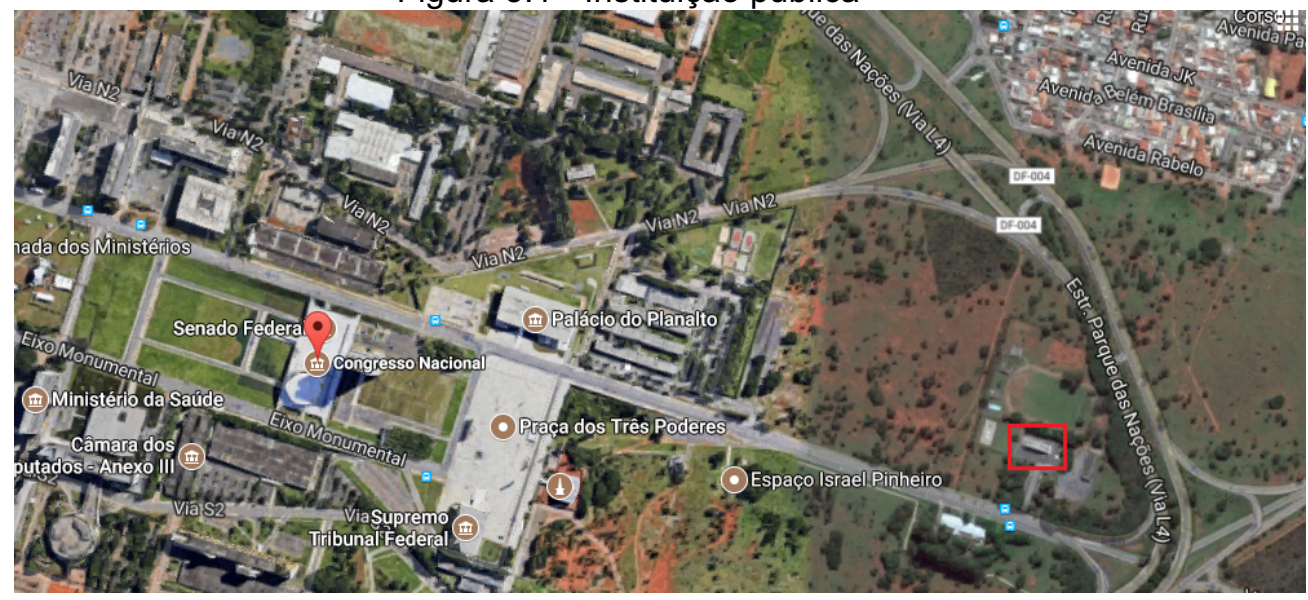

Fonte: Google Maps 
Figura 5.2 - Vista frontal da edificação

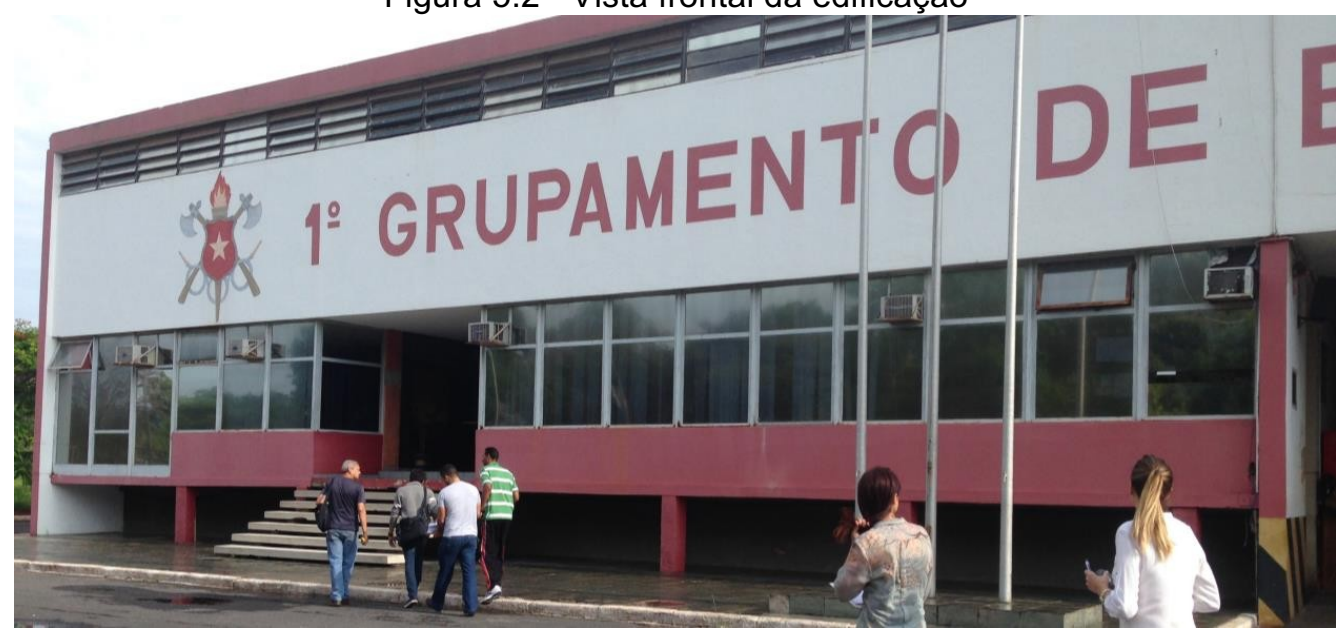

O objetivo da análise da edificação consiste em verificar a segurança estrutural para uma reforma e fazer o levantamento da estrutura, devido não existir projeto. Tendo em vista que o prédio é público e foi construído juntamente com Brasília, e, portanto, possui um valor histórico, além de tem em média 50 anos, faz necessário manter as suas características, e assim, utilizar métodos não destrutivos e semi destrutivos para a obter o projeto estrutural e verificar se a estrutura está de acordo com normas atuais, além de fazer uma inspeção do piso, parede, teto, vedações, juntas de dilatação para a reforma. O prédio possui estrutura de concreto armado, vedação de alvenaria, o revestimento da fachada é emboço de argamassa, com acabamento em pintura cor branca e vermelha.

Figura 5.3 - Vista da planta baixa do térreo

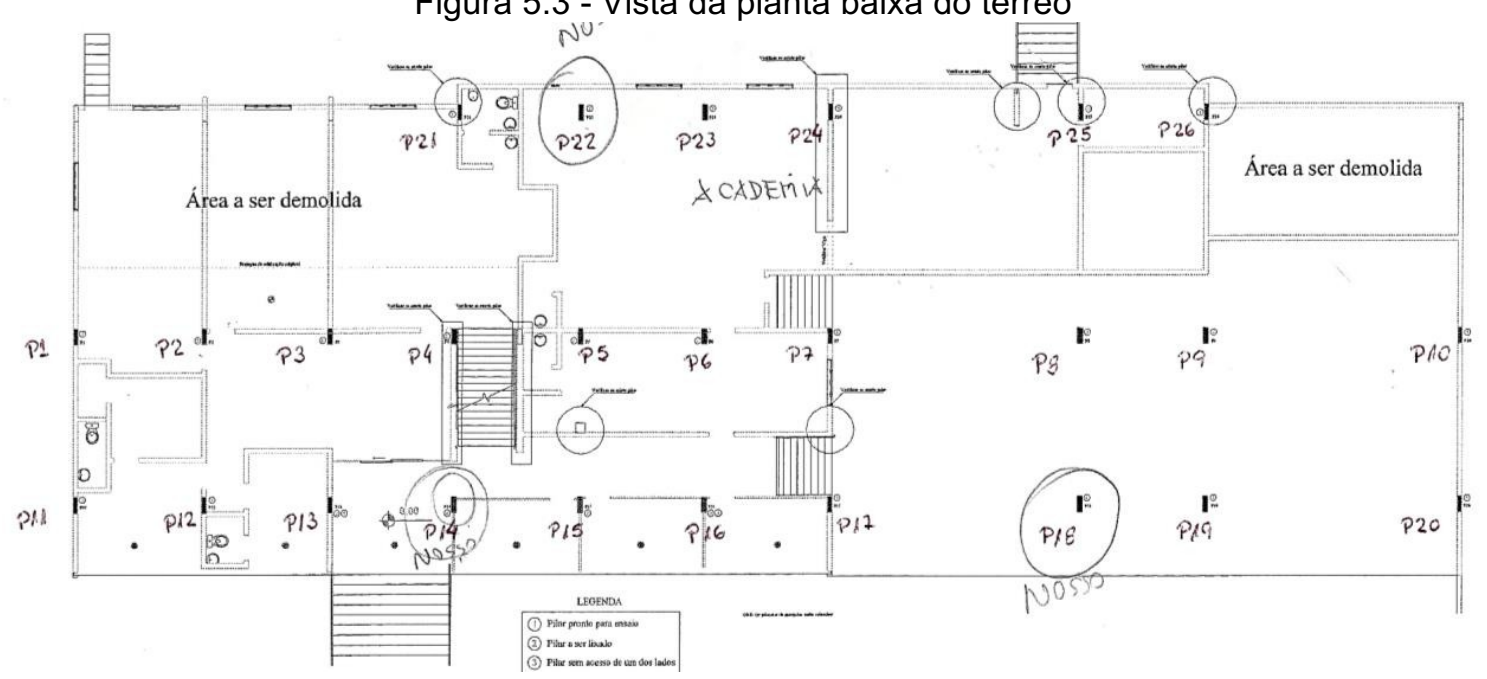


Figura 5.4 - Vista da planta baixa do $1^{\circ}$ pavimento

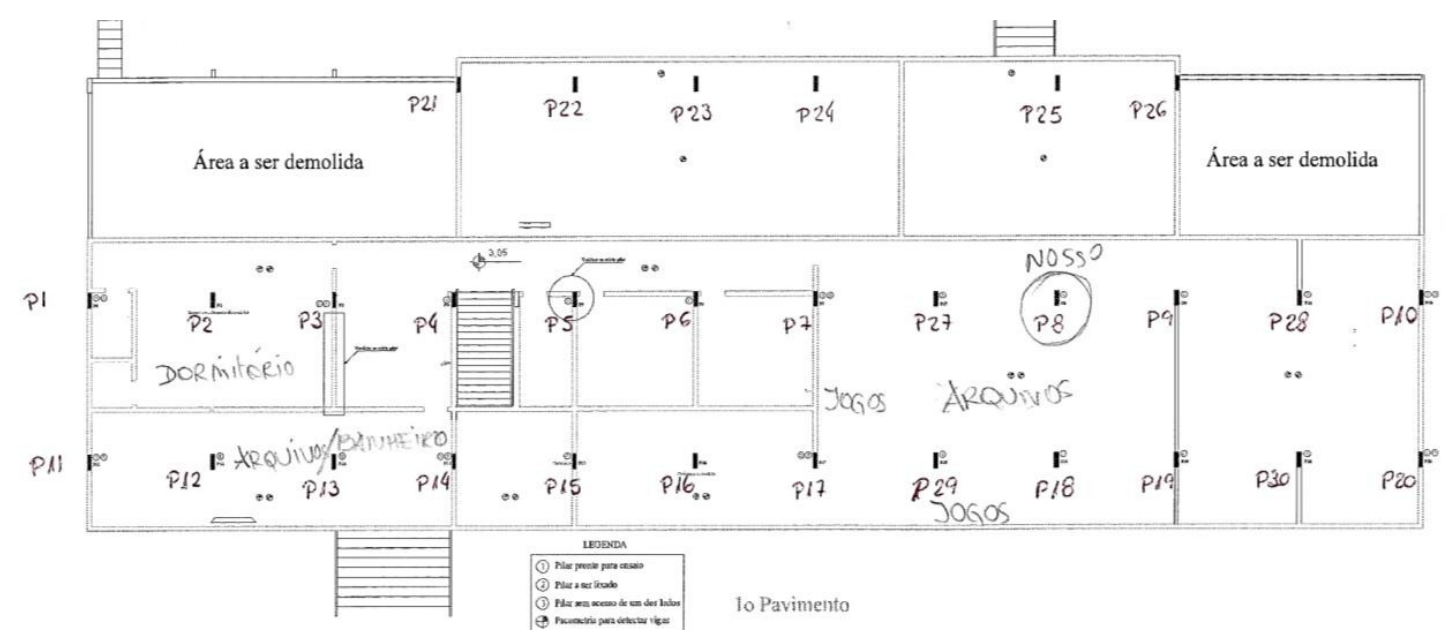

\subsubsection{ENSAIOS}

$\mathrm{Na}$ edificação, com o objetivo de verificar a segurança estrutural e fazer o levantamento da estrutura, foram executados os ensaios não destrutivos e semidestrutivos seguindo a norma especifica para cada um deles, a saber:

- Medida da frente de carbonatação com fenolftaleína em 50 pilares, sendo estes no térreo e no primeiro pavimento;

- Ensaios de detecção eletromagnética a partir do pacômetro, conforme ACl 228.2R-98, Nondestructive Test Methods for Evaluation of Concrete in Structures em 50 pilares, sendo estes no térreo e no primeiro pavimento;

- Ensaios de dureza superficial pelo esclerometro, conforme a norma ABNT NBR 7584:2012 em 50 pilares, sendo estes no térreo e no primeiro pavimento;

- Ensaios de velocidade do pulso ultrassônico, conforme a norma ABNT NBR 8802:2013 em 2 pilares no térreo;

- Extração de testemunho, conforme a norma ABNT NBR 7680 - 1:201 em 5 pilares, sendo 3 no térreo, e 2 no primeiro pavimento;

- Ensaio de Compressão de corpos de prova cilíndricos ABNT NBR 5739:2007 dos 5 testemunhos de concreto extraídos. 


\subsection{INSTITUIÇÃO PRIVADA}

\subsubsection{LOCALIZAÇÃO E DESCRIÇÃO}

A segunda estrutura localiza-se no Setor Terminal Norte, Quadra 716, Conjunto C - Brasília/DF e foram realizados ensaios coordenados pela orientadora Neusa Mota, tendo como objetivo dos ensaios detectar as causas das manifestações patologias da estrutura, pois a edificação apresentava rachaduras.

Figura 5.5 - Setor Terminal Norte, Quadra 716, Conjunto C

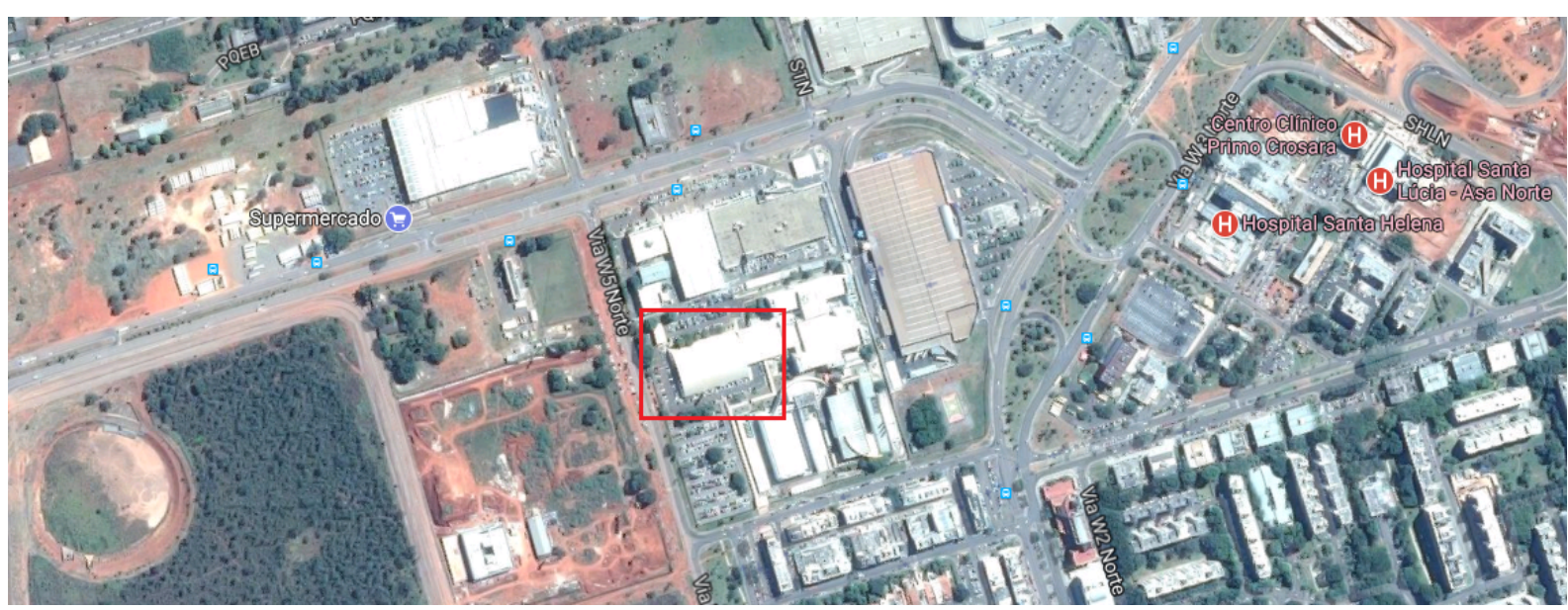

Fonte: Google Maps

\subsubsection{ENSAIOS}

$\mathrm{Na}$ instituição privada, com o objetivo de diagnosticar as causas das manifestações patológicas, foram executados os ensaios não destrutivos e semidestrutivos seguindo a norma especifica para cada um deles, a saber:

- Ensaios de detecção eletromagnética a partir do pacômetro, conforme ACl 228.2R-98, Nondestructive Test Methods for Evaluation of Concrete in Structures;

- Ensaios de dureza superficial pelo esclerometro, conforme a norma NBR 7584:2012;

- Extração de testemunho, conforme a norma ABNT NBR 7680 - 1:2015;

- Ensaio de Compressão de corpos de prova cilíndricos ABNT NBR 5739:2007;

Os ensaios de deteç̧ão eletromagnética, dureza superficial e de extração de testemunho para a determinação da resistência à compressão do concreto foram 
realizados no mesmo local, procedendo-se primeiro ao ensaio de detecção eletromagnética, em seguida de dureza superficial para posteriormente realizar a extração do testemunho.

Os ensaios foram realizados em 6 (seis) diferentes áreas, sendo 3 (três) delas realizadas no INFRA 1 em uma viga e as outras 3 (três) áreas localizadas no INFRA 2 também em uma viga. 


\section{METODOLOGIA ADOTADA}

A metodologia usada nas duas construções segue o seguinte parâmetro:

Figura 6.1 - Fluxograma da metodologia a seu utilizada

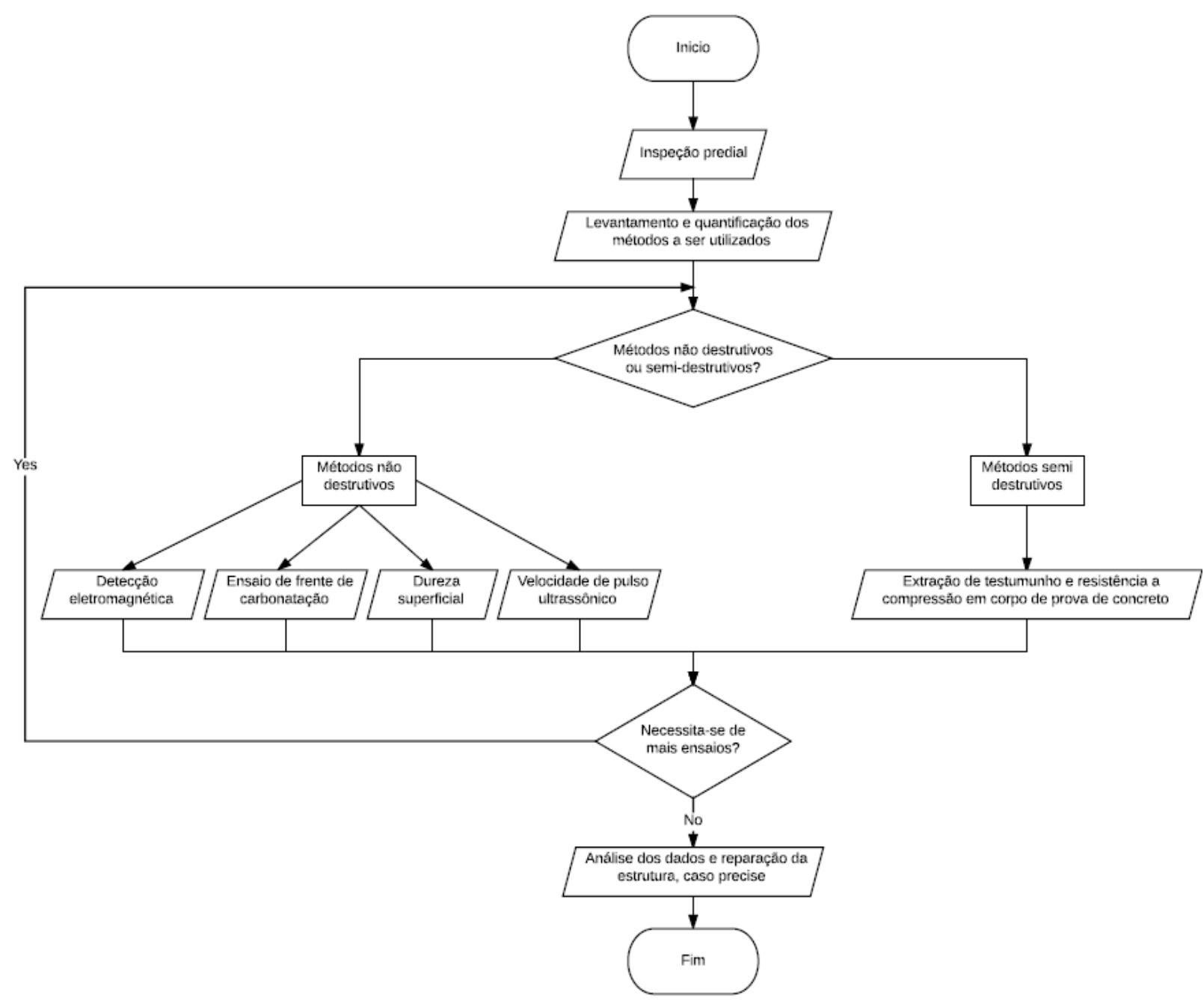

Nessa perspectiva, salienta-se que os ensaios executados seguiram as normas técnicas de cada método e quando inexistentes foram feitos conforme o passo a passo citado pela revisão bibliográfica. A seguir, detalha-se as atividades em cada edificação:

\subsection{INSTITUIÇÃO PÚBLICA}

De acordo com o fluxograma, inicialmente, realizou-se a inspeção predial e, depois, fez o levantamento e a quantificação dos ensaios, analisando conforme o 
objetivo da edificação que consistia em fazer o levantamento da armadura e da edificação para realizar o retrofit.

Primeiro ensaio executado, foi o de carbonatação com o método de aspersão de fenolftaleína, em que se fratura uma parte do pilar. Depois, reaproveitando o ensaio anterior, calibrou-se o aparelho (pacômetro) para o levantamento da armadura pelo método de detecção eletromagnética e, como forma de aprendizado, foi realizado o ensaio de pulso ultrassônico em dois pilares, P08 e P 29 do primeiro andar.

Em seguida, realizou o ensaio de dureza superficial, pelo esclerometro, juntamente com a sua análise, que foi dividida em 5 zonas devido a execução proceder em 5 dias diferentes, sendo que a escolha dos pilares foi feita de forma aleatória. Logo, calculou os valores estimados da resistência do concreto (fck) pelo método de dureza superficial correlacionando com os valores fornecidos pelo aparelho, figura 6.2 , e, assim, foram escolhidas a resistência mais baixa de cada zona para fazer a extração de testemunho.

Figura 6.2 - Correlação do índice esclerometrico e fck

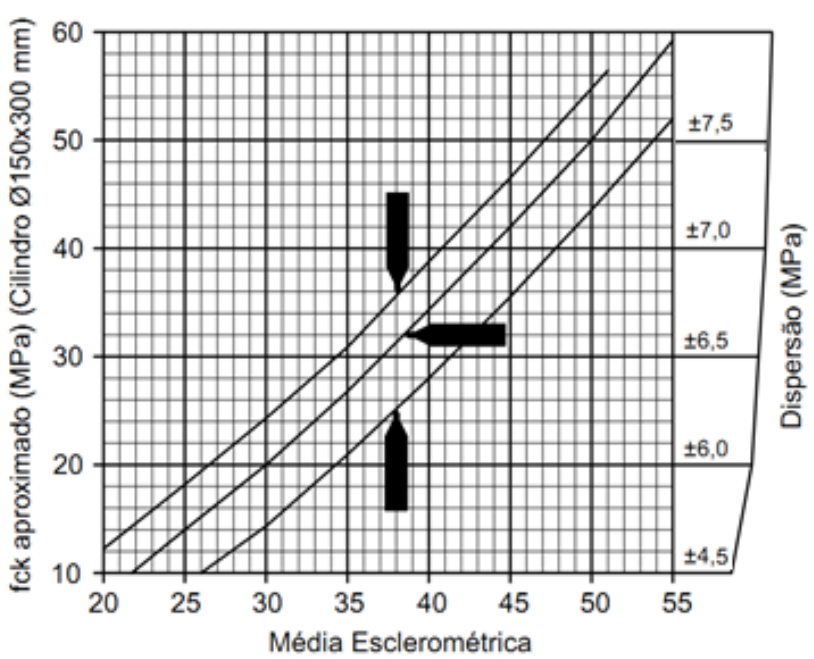

O cálculo para a resistência do concreto, inicialmente, foi determinado os diâmetros dos testemunhos com exatidão $\pm 1 \mathrm{~mm}$, pela média de dois diâmetros, medidos ortogonalmente na metade da altura e na base do corpo de prova. Já as alturas dos testemunhos foram encontradas pela medida sobre seu eixo longitudinal com precisão de $\pm 1 \mathrm{~mm}$, incluindo o capeamento. O rompimento foi feito com 0 aparelho de compressão, que mede em toneladas a carga suportada até o rompimento. 
Uma vez obtidos os resultados dos ensaios, realizou-se as análises, comparações e correlações, levando em consideração o grau de deterioração das edificações com base na idade das estruturas. Em específico, as comparações são dos dados de resistência a compressão obtidos através do método não destrutivo de dureza superficial e do método semi-destrutivo de resistência a compressão com corpos de prova extraídos da estrutura, frente de carbonatação com os índices esclerométricos. Estes foram comparados com a finalidade de descobrir a eficiência dos métodos adotados e ratificar a importância das combinações de ensaios destrutivos e semi destrutivos para a obtenção de dados mais precisos nos quesitos de análise de manifestações patológicas e durabilidade da estrutura.

\subsection{INSTITUIÇÃO PRIVADA}

A análise da edificação iniciou com uma inspeção, com foco em detectar as manifestações patológicas, o qual necessitou a realização dos ensaios de detecção eletromagnética, esclerometria e de extração de corpo de prova para a determinação de dureza superficial e de resistência à compressão do concreto, procedendo-se primeiro ao ensaio detecção eletromagnética, depois 0 de esclerometria e, em seguida, o de extração de testemunho.

O método de esclerometria, a superfície a ser ensaiada atendeu a alguns requisitos para que o ensaio fosse realizado com eficiência, tais como superfícies na vertical (elementos vigas), preferência as superfícies moldadas com formas lisas, pois fornecem melhores resultados finais, as superfícies seca, limpa e plana e o concreto ensaiado com idade superior a 28 (vinte) dias.

Assim, foram realizados para cada área escolhida duas malhas de $20 \mathrm{~cm} \times 20$ $\mathrm{cm}$, localizando as ferragens pelo pacômetro e, com o esclerometro, encontrando o índice esclerométrico com 16 pontos cada malha. O seu cálculo foi utilizado para estimar a dureza superficial e depois, por meio do gráfico de correlação do aparelho (Figura 6.3), a resistência a compressão do concreto de acordo com a posição de ensaio em campo. 
Figura 6.3 - Gráfico de correlação de Esclerometria

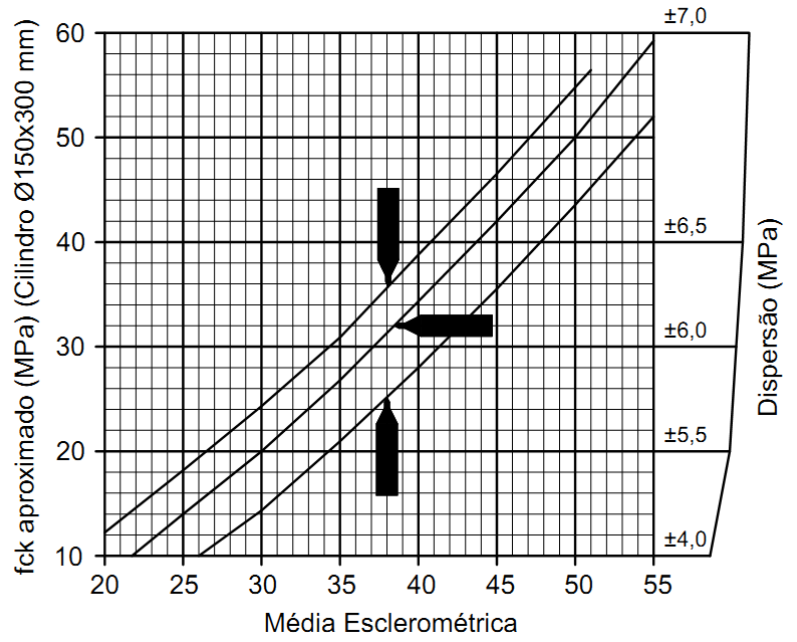

Após a determinação da resistência do concreto pelo ensaio de dureza superficial, é feito a extração do corpo de prova nas malhas em que tiveram menores resultados em cada área. O rompimento foi feito com o aparelho de compressão, que mede em toneladas a carga suportada até o rompimento. Por fim, comparou-se os métodos, como citado na metodologia da instituição pública.

\section{APRESENTAÇÃO E ANÁLISE DOS RESULTADOS}

Neste capítulo são analisados os fatores de influência nos resultados de carbonatação, índice esclerométrico, resistência à compressão com a maturidade da estrutura e apresentar os dados encontrados de velocidade de propagação.

Está dividido em duas etapas distintas. Na $1^{\text {a }}$ etapa são analisados os resultados obtidos na instituição pública e na $2^{a}$ etapa, analisados os resultados da instituição privada.

\subsection{INSTITUIÇÃO PÚBLICA}

Com base na inspeção na edificação, constatou-se que existia algumas irregularidades, tais como, ferragens e canos expostos irregularmente (Figura $7.1 \mathrm{e}$ 7.2), dutos de instalações incorretos (Figura 7.3), trincas horizontais na fachada na parte do pavimento superior juntamente com rachaduras no piso (Figura 7.4), devido a implementação dos pilares P27, P28, P29 e P30 no pavimento superior sem que houvesse uma distribuição das cargas corretamente para o térreo, o qual obteve 
uma sobre carga pontual ocasionando essa manifestação patológica, segue as imagens das irregularidades.

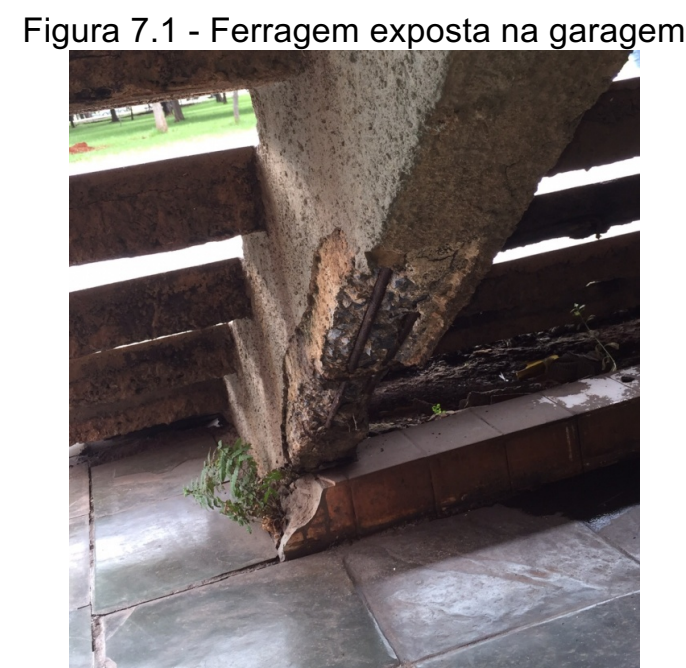

Figura 7.2 - Tubulação indevidamente exposta

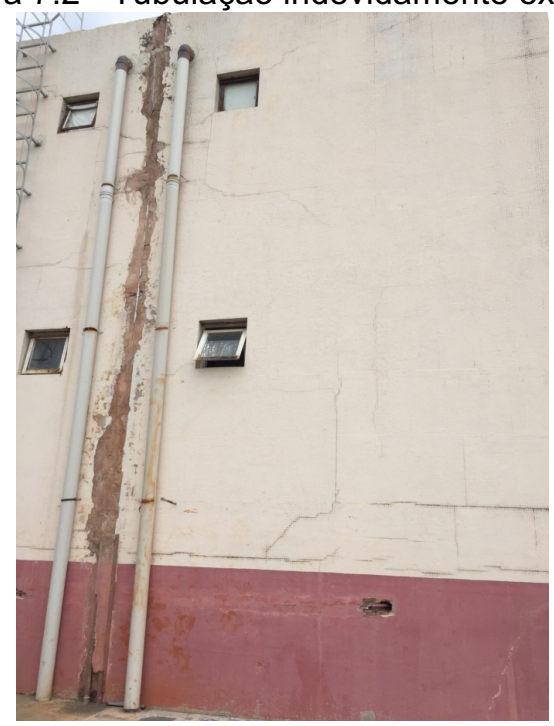

Figura 7.3 - Dutos de instalações na garagem

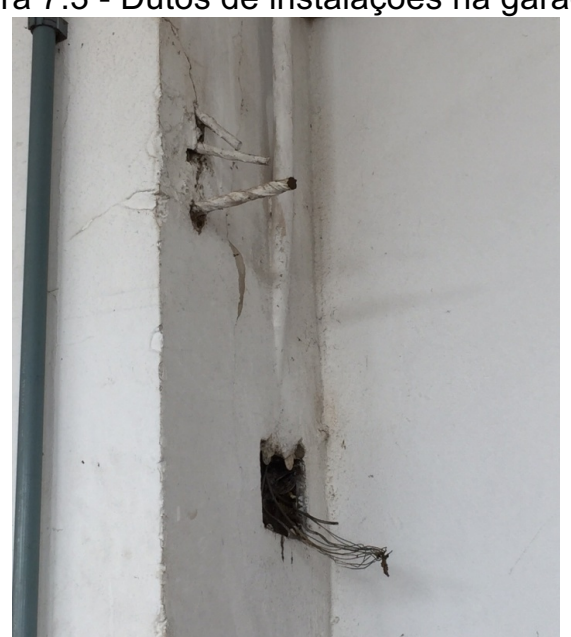


Figura 7.4 - Rachadura devido à sobrecarga
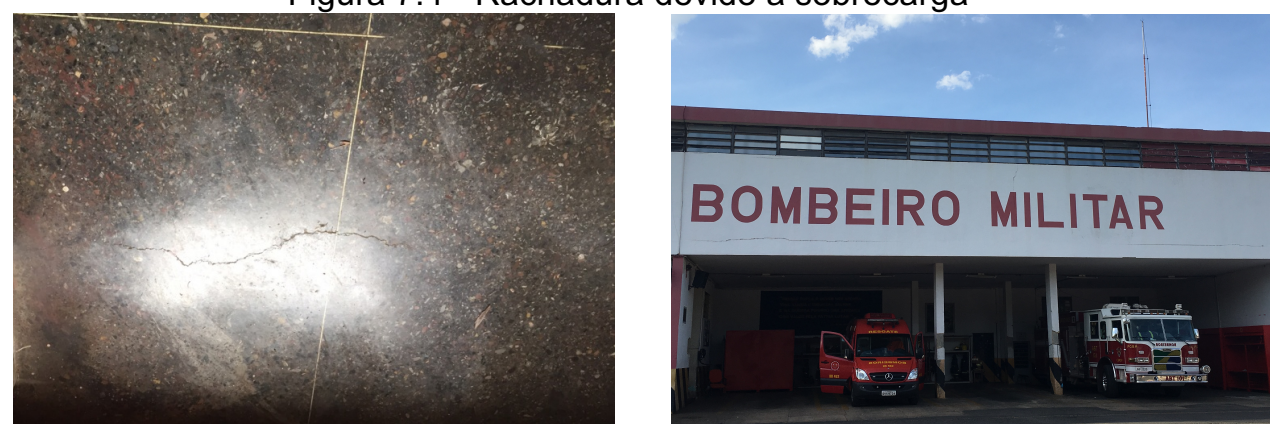

O primeiro ensaio realizado foi para determinar a frente de carbonatação, constatando-se que nenhum pilar tinha presença de carbonatação mesmo sendo uma edificação com mais de 50 anos de idade e com o cobrimento nominal menor do que o especificado na norma ABNT NBR 6118:2014, o qual determinava para ambiente urbano o cobrimento nominal de 30 milímetros. Nessa perspectiva, o concreto está com boas qualidades, não havendo, assim, interferência na análise do ensaio de esclerometria.

Figura 7.5 - Carbonatação no pilar P08

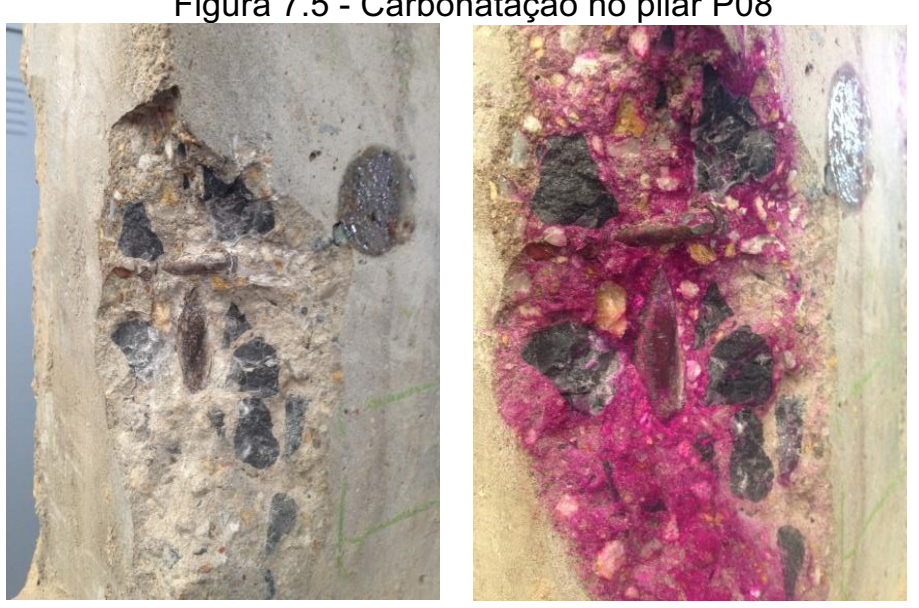

A partir na fratura no pilar, mediu-se o tamanho da bitola, pelo paquímetro, verificando que a bitola das ferragens é de 10 milímetros e,assim, deu-se início ao ensaio de detecção eletromagnética, pelo pacômetro, e posteriormente o de pulso ultrassônico como forma de aprendizado no manuseio do equipamento, contando que a qualidades dos pilares ensaios eram de média a boa (Tabela 7.1).

Após o ensaio do pulso ultrassônico, realizou-se o de esclerometria resultando em cinco zonas, inicialmente a zona 1, com menor índice esclerométrico de 32,42 no pilar P10, um pilar que se localiza na parte externa da estrutura (Tabela 7.2). 
Tabela 7.1- Ensaio de pulso ultrassônico

\begin{tabular}{|c|c|c|c|c|}
\hline \multirow{2}{*}{ Dados } & Pilar: & P06 & P08 & P29 \\
\cline { 2 - 5 } & Pavimento: & Térreo & $\mathbf{1}^{\mathbf{0}}$ & $\mathbf{1}^{\mathbf{0}}$ \\
\hline \multirow{3}{*}{ Dimensões } & $\mathrm{L} 1(\mathrm{~m})$ & 0,12 & 0,12 & 0,12 \\
\cline { 2 - 5 } & $\mathrm{L} 2(\mathrm{~m})$ & 0,40 & 0,405 & 0,40 \\
\hline \multirow{3}{*}{ Ultra-som } & $\mathrm{C} 1(\mathrm{~mm})$ & 10 & 50 & 10 \\
\cline { 2 - 5 } & $\mathrm{C} 2(\mathrm{~mm})$ & 20 & 10 & 20 \\
\cline { 2 - 5 } & $\mathrm{C} 3(\mathrm{~mm})$ & 20 & 10 & 20 \\
\cline { 2 - 5 } & $\mathrm{T}(\mu \mathrm{s})$ & 32,30 & 34,66 & 32,30 \\
\cline { 2 - 5 } & $\mathrm{L}(\mathrm{m})$ & 0,12 & 0,12 & 0,12 \\
\cline { 2 - 5 } & $\mathrm{V}(\mathrm{m} / \mathrm{s})$ & $3.715,17$ & $3.462,20$ & $3.715,17$ \\
\cline { 2 - 5 } & Qualidade do concreto & \multirow{2}{*}{ Boa } & \multirow{2}{*}{ Média } & \multirow{2}{*}{ Boa } \\
\hline
\end{tabular}

Tabela 7.2 - Índice esclerométrico e quantidade de ferragens na zona 1

\begin{tabular}{|c|c|c|c|c|c|c|c|c|c|c|}
\hline \multirow{3}{*}{$\begin{array}{c}\text { Pavimento } \\
\text { Zona } \\
\text { Leituras } \\
\end{array}$} & \multicolumn{10}{|c|}{ Térreo } \\
\hline & \multicolumn{10}{|c|}{1} \\
\hline & P01 & P07 & P08 & P09 & P10 & P11 & P17 & P18 & P19 & $\mathrm{P} 20$ \\
\hline Qtd Ø & 8 & 8 & 12 & 12 & 8 & 8 & 8 & 12 & 12 & 8 \\
\hline 1 & 40,00 & 45,00 & 42,00 & 36,00 & 32,00 & 34,00 & 38,00 & 50,00 & 40,00 & 39,00 \\
\hline 2 & 48,00 & 43,00 & 42,00 & 40,00 & 32,00 & 35,00 & 37,00 & 38,00 & 36,00 & 36,00 \\
\hline 3 & 42,00 & 30,00 & 40,00 & 48,00 & 38,00 & 44,00 & 45,00 & 42,00 & 38,00 & 41,00 \\
\hline 4 & 46,00 & 28,00 & 37,00 & 44,00 & 34,00 & 35,00 & 36,00 & 46,00 & 44,00 & 38,00 \\
\hline 5 & 38,00 & 53,00 & 42,00 & 38,00 & 32,00 & 39,00 & 40,00 & 43,00 & 41,00 & 34,00 \\
\hline 6 & 38,00 & 48,00 & 26,00 & 39,00 & 29,00 & 38,00 & 35,00 & 41,00 & 42,00 & 38,00 \\
\hline 7 & 42,00 & 45,00 & 40,00 & 42,00 & 30,00 & 36,00 & 48,00 & 36,00 & 39,00 & 36,00 \\
\hline 8 & 43,00 & 35,00 & 54,00 & 48,00 & 35,00 & 39,00 & 38,00 & 31,00 & 51,00 & 46,00 \\
\hline 9 & 38,00 & 45,00 & 45,00 & 50,00 & 32,00 & 38,00 & 34,00 & 44,00 & 48,00 & 52,00 \\
\hline 10 & 42,00 & 44,00 & 49,00 & 44,00 & 38,00 & 37,00 & 36,00 & 39,00 & 49,00 & 44,00 \\
\hline 11 & 40,00 & 50,00 & 44,00 & 42,00 & 33,00 & 42,00 & 37,00 & 38,00 & 42,00 & 42,00 \\
\hline 12 & 41,00 & 46,00 & 38,00 & 44,00 & 31,00 & 43,00 & 36,00 & 39,00 & 40,00 & 36,00 \\
\hline 13 & 41,00 & 45,00 & 38,00 & 54,00 & 32,00 & 43,00 & 41,00 & 34,00 & 46,00 & 44,00 \\
\hline 14 & 46,00 & 48,00 & 44,00 & 48,00 & 33,00 & 41,00 & 38,00 & 46,00 & 50,00 & 48,00 \\
\hline 15 & 40,00 & 28,00 & 44,00 & 48,00 & 33,00 & 32,00 & 40,00 & 36,00 & 44,00 & 34,00 \\
\hline 16 & 45,00 & 28,00 & 46,00 & 42,00 & 29,00 & 42,00 & 42,00 & 35,00 & 47,00 & 38,00 \\
\hline Média & 41,88 & 41,31 & 41,94 & 44,19 & 32,69 & 38,63 & 38,81 & 39,88 & 43,56 & 40,38 \\
\hline Média + 10\% & 46,06 & 45,44 & 46,13 & 48,61 & 35,96 & 42,49 & 42,69 & 43,86 & 47,92 & 44,41 \\
\hline Média - 10\% & 37,69 & 37,18 & 37,74 & 39,77 & 29,42 & 34,76 & 34,93 & 35,89 & 39,21 & 36,34 \\
\hline IE & 41,47 & 44,50 & 42,08 & 44,55 & 32,42 & 38,36 & 38,00 & 39,11 & 42,89 & 40,50 \\
\hline Fck (MPa) & $\begin{array}{r}41,47 \\
\pm 7,0 \\
\end{array}$ & $\begin{array}{c}44,50 \\
\pm 7,0 \\
\end{array}$ & $\begin{array}{l}42,08 \\
\pm 7,0\end{array}$ & $\begin{array}{r}44,55 \\
\pm 7,0\end{array}$ & $\begin{array}{l}32,42 \\
\pm 6,5\end{array}$ & $\begin{array}{c}38,36 \\
\pm 6,5\end{array}$ & $\begin{array}{c}38,00 \\
\pm 6,5 \\
\end{array}$ & $\begin{array}{l}39,11 \\
\pm 6,5\end{array}$ & $\begin{array}{c}42,89 \\
\pm 7,0 \\
\end{array}$ & $\begin{array}{l}40,50 \\
\pm 7,0\end{array}$ \\
\hline
\end{tabular}


Na zona 2, o índice esclerométrico menor foi 32,94 do pilar P05 (Tabela 7.3), tendo em vista que o pilar é estreito $(12 \times 40 \mathrm{~cm})$ e que existe dificuldade em concretar em estruturas esbeltes, esse pilar pode ter dito complicações na concretagem o que resultou em uma resistência menor que os demais.

Tabela 7.3 - Índice esclerométrico e quantidade de ferragens na zona 2

\begin{tabular}{|c|c|c|c|c|c|c|c|c|c|}
\hline \multirow{3}{*}{$\begin{array}{c}\text { Pavimento } \\
\text { Zonas } \\
\text { Leituras } \\
\end{array}$} & \multicolumn{9}{|c|}{ Térreo } \\
\hline & \multicolumn{9}{|c|}{2} \\
\hline & P02 & P03 & P05 & P06 & P12 & $\mathrm{P} 13$ & P14 & P15 & P16 \\
\hline Qtd Ø & 8 & 8 & 8 & 8 & 10 & 10 & 10 & 10 & 10 \\
\hline 1 & 30,00 & 34,00 & 32,00 & 30,00 & 36,00 & 36,00 & 34,00 & 36,00 & 40,00 \\
\hline 2 & 34,00 & 34,00 & 32,00 & 34,00 & 38,00 & 38,00 & 38,00 & 42,00 & 36,00 \\
\hline 3 & 34,00 & 36,00 & 26,00 & 36,00 & 34,00 & 38,00 & 36,00 & 40,00 & 42,00 \\
\hline 4 & 34,00 & 36,00 & 28,00 & 36,00 & 36,00 & 38,00 & 36,00 & 38,00 & 38,00 \\
\hline 5 & 36,00 & 36,00 & 28,00 & 34,00 & 34,00 & 38,00 & 38,00 & 40,00 & 36,00 \\
\hline 6 & 38,00 & 36,00 & 36,00 & 36,00 & 34,00 & 38,00 & 40,00 & 36,00 & 36,00 \\
\hline 7 & 38,00 & 34,00 & 28,00 & 36,00 & 34,00 & 38,00 & 34,00 & 36,00 & 38,00 \\
\hline 8 & 38,00 & 34,00 & 34,00 & 34,00 & 34,00 & 38,00 & 38,00 & 34,00 & 36,00 \\
\hline 9 & 38,00 & 36,00 & 32,00 & 32,00 & 36,00 & 38,00 & 38,00 & 34,00 & 36,00 \\
\hline 10 & 36,00 & 36,00 & 32,00 & 34,00 & 36,00 & 38,00 & 38,00 & 38,00 & 36,00 \\
\hline 11 & 40,00 & 36,00 & 36,00 & 36,00 & 34,00 & 38,00 & 38,00 & 40,00 & 36,00 \\
\hline 12 & 40,00 & 36,00 & 38,00 & 36,00 & 36,00 & 38,00 & 34,00 & 38,00 & 36,00 \\
\hline 13 & 38,00 & 34,00 & 36,00 & 36,00 & 38,00 & 36,00 & 36,00 & 38,00 & 32,00 \\
\hline 14 & 38,00 & 36,00 & 34,00 & 36,00 & 34,00 & 38,00 & 38,00 & 38,00 & 36,00 \\
\hline 15 & 40,00 & 38,00 & 32,00 & 40,00 & 38,00 & 38,00 & 38,00 & 36,00 & 36,00 \\
\hline 16 & 36,80 & 36,00 & 35,50 & 36,00 & 36,00 & 40,00 & 34,00 & 34,00 & 42,00 \\
\hline Média & 36,80 & 35,50 & 32,47 & 35,13 & 35,50 & 37,88 & 36,75 & 37,38 & 37,00 \\
\hline Média + 10\% & 40,48 & 39,05 & 35,72 & 38,64 & 39,05 & 41,66 & 40,43 & 41,11 & 40,70 \\
\hline Média - 10\% & 33,12 & 31,95 & 29,22 & 31,61 & 31,95 & 34,09 & 33,08 & 33,64 & 33,30 \\
\hline IE & 37,25 & 35,50 & 32,94 & 35,14 & 35,50 & 37,88 & 36,75 & 37,07 & 36,62 \\
\hline Fck (MPa) & $\begin{array}{l}37,25 \\
\pm 6,5\end{array}$ & $\begin{array}{l}35,50 \\
\pm 6,5\end{array}$ & $\begin{array}{c}32,94 \\
\pm 6,5\end{array}$ & $\begin{array}{c}35,14 \\
\pm 6,5\end{array}$ & $\begin{array}{c}35,50 \\
\pm 6,5\end{array}$ & $\begin{array}{l}37,88 \\
\pm 6,5\end{array}$ & $\begin{array}{l}36,75 \\
\pm 6,5\end{array}$ & $\begin{array}{l}37,07 \\
\pm 6,5\end{array}$ & $\begin{array}{c}36,62 \\
\pm 6,5\end{array}$ \\
\hline
\end{tabular}

$\mathrm{Na}$ zona 3, o índice esclerométrico menor foi 34,13 do pilar P22, tendo a esbeltes do pilar menor ainda do que o pilar P05, 12 × 25 centimétros. 
Tabela 7.4 - Índice esclerométrico e quantidade de ferragens na zona 3

\begin{tabular}{|c|c|c|c|c|c|c|}
\hline Pavimento & \multicolumn{7}{|c|}{ Térreo } \\
\hline Zonas & \multicolumn{7}{|c|}{3} \\
\hline Leituras & P21 & P22 & P23 & P24 & P25 & P26 \\
\hline Qtd Ø & 8 & 8 & 8 & 8 & 8 & 8 \\
\hline 1 & 30,00 & 32,00 & 36,00 & 46,00 & 38,00 & 38,00 \\
\hline 2 & 38,00 & 34,00 & 38,00 & 44,00 & 36,00 & 40,00 \\
\hline 3 & 30,00 & 34,00 & 36,00 & 44,00 & 28,00 & 46,00 \\
\hline 4 & 32,00 & 36,00 & 30,00 & 44,00 & 42,00 & 40,00 \\
\hline 5 & 38,00 & 36,00 & 38,00 & 44,00 & 28,00 & 38,00 \\
\hline 6 & 36,00 & 34,00 & 34,00 & 40,00 & 28,00 & 40,00 \\
\hline 7 & 34,00 & 32,00 & 32,00 & 42,00 & 36,00 & 40,00 \\
\hline 8 & 34,00 & 36,00 & 36,00 & 38,00 & 38,00 & 42,00 \\
\hline 9 & 38,00 & 34,00 & 36,00 & 44,00 & 36,00 & 42,00 \\
\hline 10 & 28,00 & 36,00 & 36,00 & 42,00 & 36,00 & 40,00 \\
\hline 11 & 34,00 & 32,00 & 34,00 & 44,00 & 34,00 & 36,00 \\
\hline 12 & 40,00 & 36,00 & 32,00 & 32,00 & 30,00 & 30,00 \\
\hline 13 & 30,00 & 32,00 & 34,00 & 36,00 & 38,00 & 36,00 \\
\hline 14 & 38,00 & 34,00 & 32,00 & 40,00 & 28,00 & 38,00 \\
\hline 15 & 40,00 & 34,00 & 38,00 & 32,00 & 30,00 & 36,00 \\
\hline 16 & 34,67 & 34,13 & 34,80 & 40,80 & 33,73 & 38,80 \\
\hline Média & 34,67 & 34,13 & 34,80 & 40,80 & 33,73 & 38,80 \\
\hline Média + 10\% & 38,13 & 37,55 & 38,28 & 44,88 & 37,11 & 42,68 \\
\hline Média - 10\% & 31,20 & 30,72 & 31,32 & 36,72 & 30,36 & 34,92 \\
\hline IE & 35,67 & 34,13 & 35,12 & 42,23 & 35,29 & 38,91 \\
\hline Fck (MPa) & 35,67 & 34,13 & 35,12 & 42,23 & 35,29 & 38,91 \\
$\pm 6,5$ & $\pm 6,5$ & $\pm 6,5$ & $\pm 7,0$ & $\pm 6,5$ & $\pm 6,5$ \\
\hline
\end{tabular}

A zona 4 foi separada em duas tabelas (7.5 e 7.6) e o índice esclerométrico menor foi 29,54 do pilar P20 e em seguida o do pilar P10 com resultado de 30,36. Ambos os pilares se localiza na parte externa da estrutura, o qual a incidência de agentes nocivos ao concreto é maior, o que facilita na perda de resistência. 
Tabela 7.5 - Índice esclerométrico e quantidade de ferragens na zona 4

\begin{tabular}{|c|c|c|c|c|c|c|c|c|c|}
\hline Pavimento & \multicolumn{7}{|c|}{$1{ }^{\circ}$ Pavimento } \\
\hline Zonas & \multicolumn{7}{|c|}{4} \\
\hline Leituras & $\mathrm{P} 01$ & $\mathrm{P} 02$ & $\mathrm{P} 03$ & $\mathrm{P} 04$ & $\mathrm{P} 06$ & $\mathrm{P} 07$ & $\mathrm{P} 08$ & $\mathrm{P} 09$ & $\mathrm{P} 10$ \\
\hline Qtd Ø & 8 & 8 & 8 & 8 & 8 & 8 & 8 & 8 & 8 \\
\hline 1 & 34,00 & 32,00 & 34,00 & 34,00 & 32,00 & 30,00 & 36,00 & 40,00 & 30,00 \\
\hline 2 & 36,00 & 34,00 & 32,00 & 34,00 & 38,00 & 32,00 & 48,00 & 40,00 & 36,00 \\
\hline 3 & 36,00 & 34,00 & 32,00 & 36,00 & 34,00 & 36,00 & 38,00 & 44,00 & 36,00 \\
\hline 4 & 36,00 & 36,00 & 34,00 & 36,00 & 34,00 & 30,00 & 32,00 & 44,00 & 32,00 \\
\hline 5 & 34,00 & 38,00 & 34,00 & 36,00 & 34,00 & 32,00 & 34,00 & 44,00 & 32,00 \\
\hline 6 & 36,00 & 32,00 & 34,00 & 38,00 & 34,00 & 32,00 & 33,00 & 44,00 & 38,00 \\
\hline 7 & 34,00 & 34,00 & 36,00 & 36,00 & 34,00 & 32,00 & 36,00 & 42,00 & 24,00 \\
\hline 8 & 34,00 & 34,00 & 36,00 & 38,00 & 34,00 & 32,00 & 36,00 & 46,00 & 30,00 \\
\hline 9 & 34,00 & 38,00 & 36,00 & 38,00 & 32,00 & 36,00 & 36,00 & 44,00 & 26,00 \\
\hline 10 & 28,00 & 38,00 & 36,00 & 40,00 & 32,00 & 36,00 & 34,00 & 40,00 & 30,00 \\
\hline 11 & 36,00 & 36,00 & 34,00 & 38,00 & 30,00 & 36,00 & 38,00 & 42,00 & 30,00 \\
\hline 12 & 36,00 & 32,00 & 36,00 & 34,00 & 30,00 & 36,00 & 38,00 & 40,00 & 32,00 \\
\hline 13 & 36,00 & 36,00 & 38,00 & 34,00 & 36,00 & 34,00 & 38,00 & 42,00 & 32,00 \\
\hline 14 & 28,00 & 34,00 & 36,00 & 40,00 & 38,00 & 36,00 & 50,00 & 40,00 & 28,00 \\
\hline 15 & 40,00 & 34,00 & 36,00 & 36,00 & 38,00 & 36,00 & 38,00 & 38,00 & 30,00 \\
\hline 16 & 34,00 & 38,00 & 36,00 & 38,00 & 36,00 & 32,00 & 34,00 & 44,00 & 28,00 \\
\hline Média & 34,50 & 35,00 & 35,00 & 36,63 & 34,13 & 33,63 & 37,44 & 42,13 & 30,88 \\
\hline Média - 10\% & 37,95 & 38,50 & 38,50 & 40,29 & 37,54 & 36,99 & 41,18 & 46,34 & 33,96 \\
\hline IE & 35,08 & 31,50 & 31,50 & 32,96 & 30,71 & 30,26 & 33,69 & 37,91 & 27,79 \\
\hline Fck (MPa) & 35,08 & 35,00 & 35,00 & 36,63 & 33,82 & 34,14 & 36,33 & 42,13 & 30,36 \\
\hline & $\pm 6,5$ & $\pm 6,5$ & $\pm 6,5$ & $\pm 6,5$ & $\pm 6,5$ & $\pm 6,5$ & $\pm 6,5$ & $\pm 7,0$ & $\pm 6,5$ \\
\hline
\end{tabular}


Tabela 7.6 - Índice esclerométrico e quantidade de ferragens na zona 4

\begin{tabular}{|c|c|c|c|c|c|c|c|c|c|}
\hline Pavimento & \multicolumn{7}{|c|}{$1{ }^{\circ}$ Pavimento } \\
\hline Zonas & \multicolumn{7}{|c|}{4} \\
\hline Leituras & P11 & P12 & P13 & P14 & P16 & P17 & P18 & P19 & P20 \\
\hline Qtd Ø & 8 & 8 & 8 & 8 & 8 & 8 & 8 & 8 & 8 \\
\hline 1 & 40,00 & 36,00 & 36,00 & 36,00 & 38,00 & 34,00 & 38,00 & 38,00 & 30,00 \\
\hline 2 & 42,00 & 24,00 & 42,00 & 32,00 & 38,00 & 38,00 & 35,00 & 36,00 & 30,00 \\
\hline 3 & 38,00 & 36,00 & 36,00 & 34,00 & 36,00 & 42,00 & 42,00 & 44,00 & 24,00 \\
\hline 4 & 36,00 & 36,00 & 34,00 & 32,00 & 36,00 & 38,00 & 37,00 & 38,00 & 26,00 \\
\hline 5 & 36,00 & 30,00 & 32,00 & 32,00 & 38,00 & 36,00 & 39,00 & 42,00 & 32,00 \\
\hline 6 & 36,00 & 34,00 & 34,00 & 32,00 & 38,00 & 38,00 & 44,00 & 40,00 & 30,00 \\
\hline 7 & 38,00 & 38,00 & 40,00 & 32,00 & 36,00 & 40,00 & 36,00 & 40,00 & 28,00 \\
\hline 8 & 38,00 & 36,00 & 36,00 & 30,00 & 34,00 & 36,00 & 46,00 & 42,00 & 28,00 \\
\hline 9 & 38,00 & 46,00 & 34,00 & 32,00 & 42,00 & 34,00 & 43,00 & 42,00 & 28,00 \\
\hline 10 & 36,00 & 36,00 & 38,00 & 32,00 & 42,00 & 34,00 & 40,00 & 42,00 & 30,00 \\
\hline 11 & 40,00 & 38,00 & 34,00 & 32,00 & 40,00 & 34,00 & 38,00 & 41,00 & 30,00 \\
\hline 12 & 32,00 & 34,00 & 36,00 & 34,00 & 40,00 & 32,00 & 38,00 & 44,00 & 28,00 \\
\hline 13 & 40,00 & 44,00 & 46,00 & 32,00 & 38,00 & 36,00 & 48,00 & 40,00 & 30,00 \\
\hline 14 & 38,00 & 36,00 & 44,00 & 32,00 & 40,00 & 40,00 & 44,00 & 40,00 & 28,00 \\
\hline 15 & 34,00 & 40,00 & 40,00 & 34,00 & 42,00 & 42,00 & 44,00 & 36,00 & 32,00 \\
\hline 16 & 36,00 & 36,00 & 42,00 & 36,00 & 44,00 & 40,00 & 34,00 & 37,00 & 36,00 \\
\hline Média & 37,38 & 36,25 & 37,75 & 32,75 & 38,88 & 37,13 & 40,38 & 40,13 & 29,38 \\
\hline Média + 10\% & 41,11 & 39,88 & 41,53 & 36,03 & 42,76 & 40,84 & 44,41 & 44,14 & 32,31 \\
\hline IE & 33,64 & 32,63 & 33,98 & 29,48 & 34,99 & 33,41 & 36,34 & 36,11 & 26,44 \\
\hline Fck (MPa) & 37,43 & 36,00 & 36,18 & 32,75 & 38,86 & 36,77 & 40,64 & 40,71 & 29,54 \\
\hline $\pm 6,5$ & 36,00 & 36,18 & 32,75 & 38,86 & 36,77 & 40,64 & 40,71 & 29,54 \\
$\pm 6,5$ & $\pm 6,5$ & $\pm 6,5$ & $\pm 6,5$ & $\pm 6,5$ & $\pm 7,0$ & $\pm 7,0$ & $\pm 6,0$ \\
\hline
\end{tabular}

Na zona 5, o índice esclerométrico menor foi 30 do pilar P28, que consiste no pilar construído sem a distribuições das cargas corretamente. 
Tabela 7.7 - Índice esclerométrico e quantidade de ferragens na zona 5

\begin{tabular}{|c|c|c|c|c|}
\hline \multirow{2}{*}{$\begin{array}{c}\text { Pavimento } \\
\text { Zonas } \\
\end{array}$} & \multicolumn{4}{|c|}{$1^{\circ}$ Pavimento } \\
\hline & \multicolumn{4}{|c|}{5} \\
\hline Leituras & P27 & P28 & P29 & P30 \\
\hline Qtd Ø & 8 & 8 & 8 & 8 \\
\hline 1 & 38,00 & 30,00 & 42,00 & 40,00 \\
\hline 2 & 44,00 & 32,00 & 40,00 & 42,00 \\
\hline 3 & 38,00 & 32,00 & 42,00 & 46,00 \\
\hline 4 & 38,00 & 28,00 & 38,00 & 44,00 \\
\hline 5 & 38,00 & 32,00 & 38,00 & 42,00 \\
\hline 6 & 34,00 & 34,00 & 42,00 & 44,00 \\
\hline 7 & 34,00 & 30,00 & 36,00 & 44,00 \\
\hline 8 & 38,00 & 30,00 & 36,00 & 32,00 \\
\hline 9 & 36,00 & 28,00 & 38,00 & 46,00 \\
\hline 10 & 34,00 & 28,00 & 38,00 & 48,00 \\
\hline 11 & 32,00 & 26,00 & 38,00 & 40,00 \\
\hline 12 & 30,00 & 32,00 & 38,00 & 42,00 \\
\hline 13 & 36,00 & 28,00 & 38,00 & 36,00 \\
\hline 14 & 32,00 & 24,00 & 40,00 & 38,00 \\
\hline 15 & 32,00 & 36,00 & 38,00 & 38,00 \\
\hline 16 & 32,00 & 30,00 & 36,00 & 30,00 \\
\hline Média & 35,38 & 30,00 & 38,63 & 40,75 \\
\hline Média + 10\% & 38,91 & 33,00 & 42,49 & 44,83 \\
\hline Média - 10\% & 31,84 & 27,00 & 34,76 & 36,68 \\
\hline IE & 35,14 & 30,00 & 38,63 & 41,40 \\
\hline Fck (MPa) & $35,14 \pm 6,5$ & $30,00 \pm 6,5$ & $38,63 \pm 6,5$ & $41,40 \pm 7,0$ \\
\hline
\end{tabular}

Após ter analisado os índices esclerométricos e escolhidos os menores valores de cada zona, realizou-se a extração dos testemunhos destes pilares, o qual foi realizado conforme a norma ABNT NBR 7680-1:2015.

Figura 7.6 - Extração do testemunho do pilar 10 do térreo

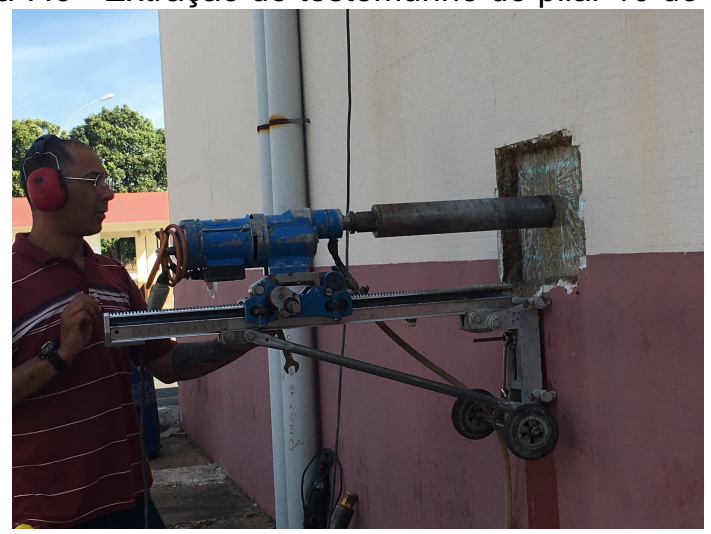


Figura 7.7 - Extração de testemunho do pilar 20 do $1^{\circ}$ Pavimento

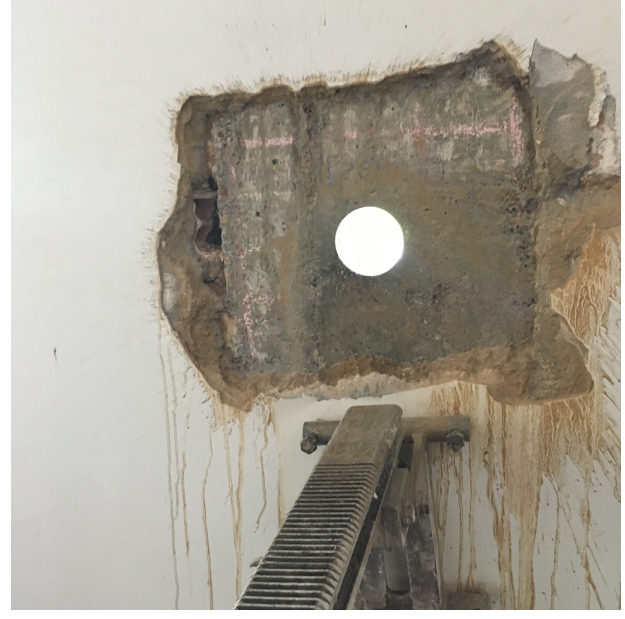

Devido o pilar P22 ter uma estrutura pequena e ferragens muito próximas, ao extrair o testemunho foi cortado uma parte da armação, conforme a figura 7.8:

Figura 7.8 - Extração do testemunho do pilar 22 do térreo
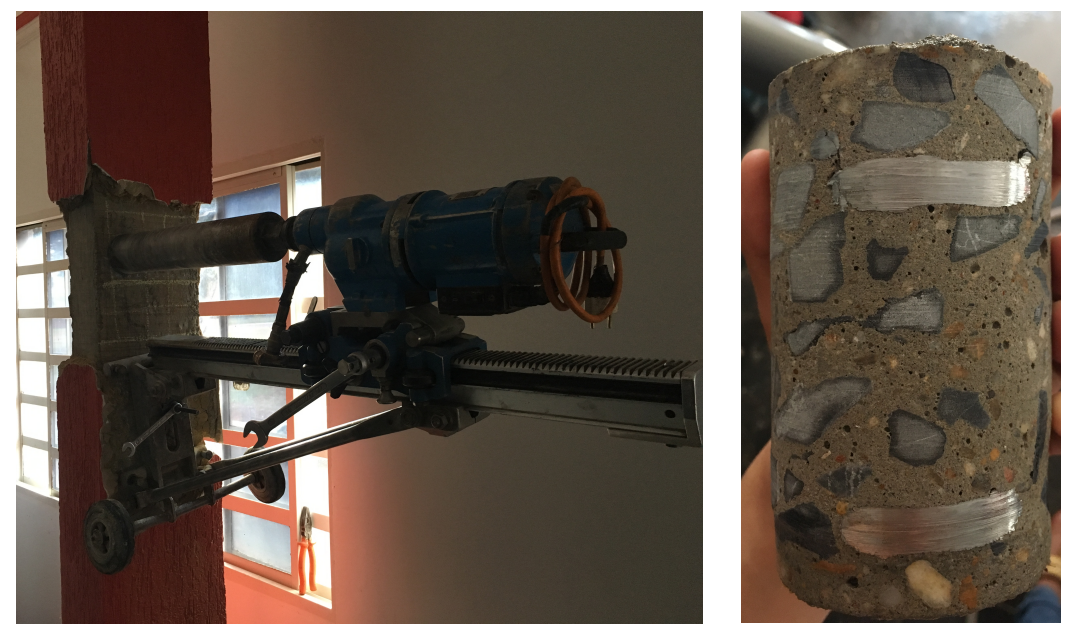

Figura 7.9 - Rompimento do testemunho do Pilar 10

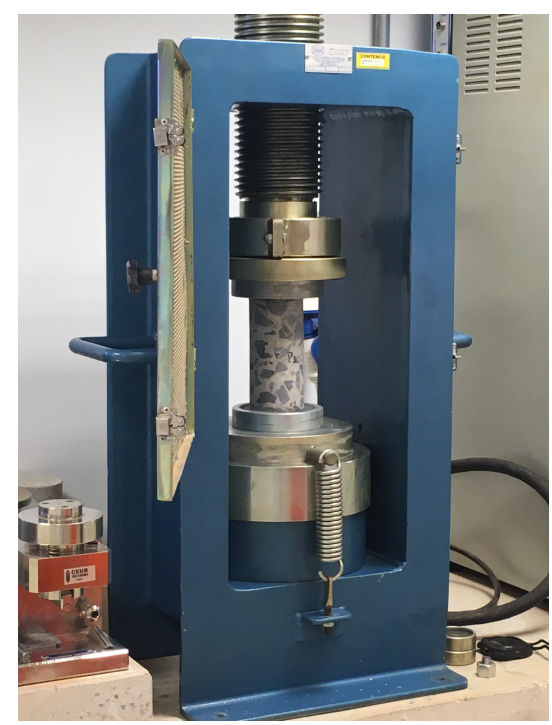


Tabela 7.8- Resistência a compressão

\begin{tabular}{|c|c|c|c|c|c|}
\hline PILAR & $\begin{array}{l}\text { P20 (10 Pav } \\
\text { alojamento) }\end{array}$ & $\begin{array}{l}\text { P10 (Térreo } \\
\text { garagem) }\end{array}$ & $\begin{array}{l}\text { P28 (10 Pav } \\
\text { alojamento) }\end{array}$ & $\begin{array}{c}\text { P22 (Térreo } \\
\text { academia) }\end{array}$ & $\begin{array}{l}\text { P5 (Térreo } \\
\text { secretaria) }\end{array}$ \\
\hline Diâmetro (mm) & 73,765 & 73,852 & 73,855 & 73,772 & 73,888 \\
\hline Altura $(\mathrm{mm})$ & 150,548 & 149,428 & 121,460 & 119,640 & 120,550 \\
\hline Relação H/D & 2,04 & 2,02 & 1,64 & 1,62 & 1,63 \\
\hline Área $\left(\mathrm{cm}^{2}\right)$ & 42,74 & 42,84 & 42,84 & 42,74 & 42,88 \\
\hline Volume $\left(\mathrm{cm}^{3}\right)$ & 643,38 & 640,10 & 520,33 & 511,39 & 516,90 \\
\hline Peso (g) & $1.528,00$ & $1.506,00$ & $1.232,00$ & $1.224,00$ & $1.244,00$ \\
\hline $\begin{array}{l}\text { Peso específico } \\
\left(\mathrm{Kg} / \mathrm{m}^{3}\right)\end{array}$ & $2.374,97$ & $2.352,77$ & $2.367,71$ & $2.393,49$ & $2.406,66$ \\
\hline $\mathrm{Nc}(\mathrm{tf})$ & 6,85 & 12,62 & 12,25 & 9,25 & 10,48 \\
\hline Fci,ext,inicial (MPa) & 16,03 & 29,46 & 28,59 & 21,64 & 24,44 \\
\hline K1 & 0,00 & 0,00 & $-0,03$ & $-0,03$ & $-0,03$ \\
\hline $\mathrm{K} 2$ & 0,09 & 0,09 & 0,09 & 0,09 & 0,09 \\
\hline K3 & 0,05 & 0,05 & 0,05 & 0,05 & 0,05 \\
\hline K4 & $-0,04$ & $-0,04$ & $-0,04$ & $-0,04$ & $-0,04$ \\
\hline K & 0,10 & 0,10 & 0,07 & 0,07 & 0,07 \\
\hline Fci,ext (MPa) & 17,63 & 32,41 & 30,60 & 23,16 & 26,15 \\
\hline Fck,ext,seg (MPA) & & \multicolumn{4}{|c|}{28,08} \\
\hline $\pm 15 \%$ da média & $37,20 \%$ & $15,42 \%$ & $8,97 \%$ & $17,53 \%$ & $6,86 \%$ \\
\hline Redivisão dos lotes & & \multicolumn{2}{|c|}{ Lote 01} & \multicolumn{2}{|c|}{ Lote 02} \\
\hline Fck,ext,seg (MPa) & & \multicolumn{2}{|c|}{31,50} & \multicolumn{2}{|c|}{24,65} \\
\hline $\pm 15 \%$ da média & & $2,87 \%$ & $2,87 \%$ & $6,08 \%$ & $6,08 \%$ \\
\hline$\gamma c$ & & \multicolumn{4}{|c|}{1,27} \\
\hline Fcd (Mpa) & & \multicolumn{2}{|c|}{24,80} & \multicolumn{2}{|c|}{19,41} \\
\hline Fcd médio (Mpa) & & \multicolumn{4}{|c|}{22,11} \\
\hline
\end{tabular}

O corpo de testemunho do Pilar P20 retirado do $1^{\circ}$ Pavimento obteve um erro devido ao uso do neoprene como forma de regularizar a base do testemunho, resultando em um dado não coerente. Os outros testemunhos foram capeados com uma nata de cimento, conforme a norma ABNT NBR 5738:2015, obtendo o peso dos testemunhos antes de capear. Dessa forma, obteve-se a média do fck,ext,seg de 28,08 MPa, retirando o resultado errôneo do Pilar P20. Em seguida, verificou que média divergiu mais do que $15 \%$ do fci,ext dos pilares, sendo necessário a dividir em dois lotes, gerando em dois fck,ext,seg, um de 31,50 MPa e o outro de 24,65 MPa. Para verificar os cálculos da estrutura é necessário utilizar a minoração de $\gamma c$ prevista na ABNT NBR 6118:2014, para essa estrutura o coeficiente $\gamma c$ é 1,4, porém como é um testemunho extraído da estrutura esse coeficiente tem que ser dividido 
por 1,1, resultando em um coeficiente de 1,27. Dessa forma, a resistência de cálculo à compressão do concreto (fcd) média é de $22,11 \mathrm{MPa}$, o qual pode-se concluir que o fck adotado foi de 20 MPa (tabela 7.8).

A figura a seguir mostra a comparação dos ensaios de esclerometria e o ensaio de compressão e identifica-se que os ensaio de esclerometria não resulta em dados precisos, mas tem como ter uma base do fck no local.

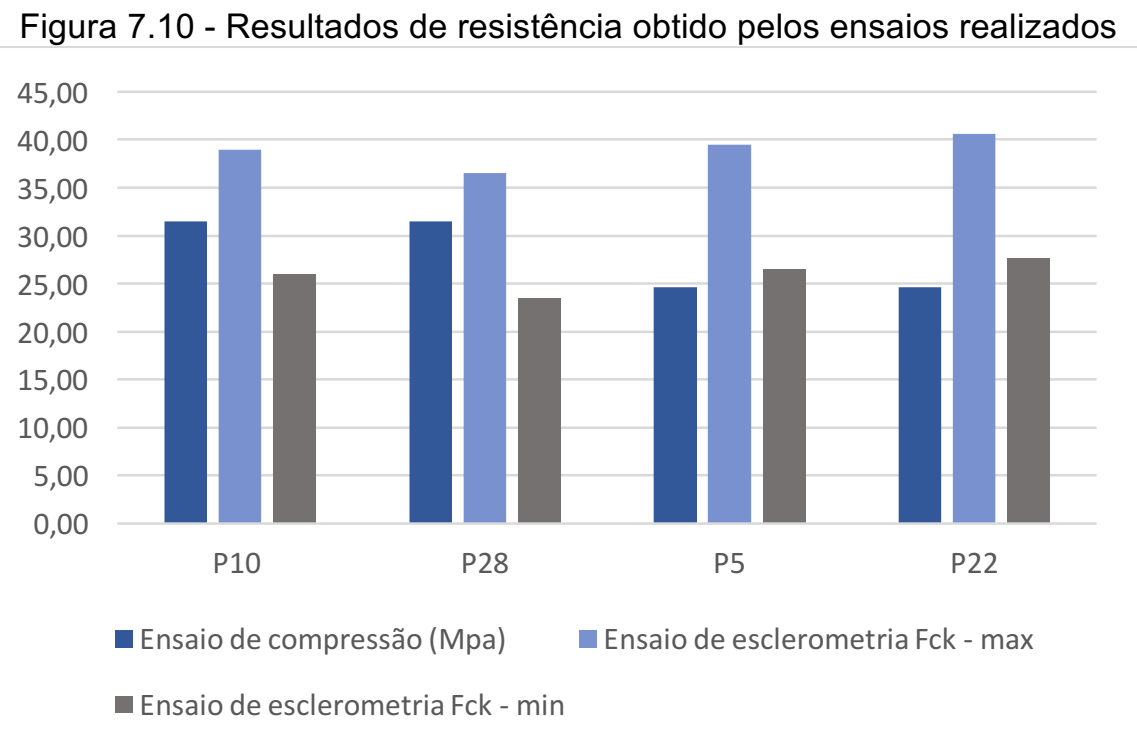

\subsection{INSTITUIÇÃO PRIVADA}

Os resultados estão apresentados em ordem numérica crescente referente ao número da área delimitada para o ensaio, sua localização está apresenta nas Figuras 4.6 e 4.7 .

Destaca-se que as peças foram ensaiadas com o esclerômetro na posição horizontal. Os resultados da esclerometria no INFRA I e INFRA II encontram-se nas tabelas a seguir. 
Tabela 7.9 - Resultados da Esclerometria no INFRA 1

\begin{tabular}{|c|c|c|c|c|c|c|}
\hline \multirow{3}{*}{ Leitura } & \multicolumn{6}{|c|}{ ELEMENTOS } \\
\hline & \multicolumn{2}{|c|}{01} & \multicolumn{2}{|c|}{02} & \multicolumn{2}{|c|}{03} \\
\hline & Ensaio 01 & Ensaio 02 & Ensaio 01 & Ensaio 02 & Ensaio 01 & Ensaio 02 \\
\hline 1 & 44 & 44 & 52 & 44 & 48 & 50 \\
\hline 2 & 50 & 44 & 38 & 44 & 48 & 51 \\
\hline 3 & 48 & 46 & 42 & 46 & 48 & 48 \\
\hline 4 & 40 & 48 & 44 & 46 & 54 & 46 \\
\hline 5 & 44 & 48 & 44 & 52 & 48 & 48 \\
\hline 6 & 44 & 46 & 50 & 42 & 48 & 48 \\
\hline 7 & 42 & 36 & 44 & 44 & 54 & 45 \\
\hline 8 & 44 & 42 & 42 & 50 & 50 & 51 \\
\hline 9 & 46 & 48 & 44 & 40 & 56 & 54 \\
\hline 10 & 50 & 50 & 40 & 42 & 48 & 54 \\
\hline 11 & 50 & 42 & 44 & 40 & 48 & 49 \\
\hline 12 & 42 & 46 & 40 & 44 & 56 & 54 \\
\hline 13 & 48 & 42 & 44 & 40 & 48 & 52 \\
\hline 14 & 46 & 46 & 36 & 44 & 48 & 48 \\
\hline 15 & 48 & 40 & 44 & 44 & 47 & 50 \\
\hline 16 & 48 & 40 & 42 & 44 & 53 & 44 \\
\hline Média & 45,9 & 44,3 & 43,1 & 44,1 & 50,1 & 49,5 \\
\hline Média + 10\% & 50,49 & 48,73 & 47,41 & 48,51 & 55,11 & 54,89 \\
\hline Média - 10\% & 41,31 & 39,87 & 38,79 & 39,69 & 45,09 & 44,91 \\
\hline IE & 46,3 & 44,4 & 42,8 & 43,1 & 49,3 & 49,9 \\
\hline Fck (MPa) & $43,9 \pm 6,5$ & $40,9 \pm 6,5$ & $38,4 \pm 6,0$ & $38,9 \pm 6,0$ & $48,8 \pm 6,5$ & $49,8 \pm 6,5$ \\
\hline
\end{tabular}

Tabela 7.10 - Resultados da Esclerometria no INFRA 2

\begin{tabular}{|c|c|c|c|c|c|c|}
\hline \multirow{3}{*}{ Leitura } & \multicolumn{6}{|c|}{ ELEMENTOS } \\
\hline & \multicolumn{2}{|c|}{04} & \multicolumn{2}{|c|}{05} & \multicolumn{2}{|c|}{06} \\
\hline & Ensaio 01 & Ensaio 02 & Ensaio 01 & Ensaio 02 & Ensaio 01 & Ensaio 02 \\
\hline 1 & 46 & 42 & 48 & 44 & 43 & 44 \\
\hline 2 & 40 & 40 & 49 & 52 & 42 & 47 \\
\hline 3 & 42 & 42 & 44 & 42 & 46 & 46 \\
\hline 4 & 40 & 40 & 52 & 50 & 46 & 46 \\
\hline 5 & 44 & 41 & 40 & 42 & 40 & 48 \\
\hline 6 & 41 & 46 & 48 & 48 & 50 & 49 \\
\hline 7 & 44 & 43 & 48 & 52 & 44 & 46 \\
\hline 8 & 44 & 40 & 38 & 44 & 38 & 50 \\
\hline 9 & 40 & 43 & 40 & 43 & 44 & 50 \\
\hline 10 & 44 & 40 & 40 & 42 & 40 & 44 \\
\hline 11 & 50 & 45 & 34 & 32 & 42 & 43 \\
\hline 12 & 45 & 44 & 36 & 46 & 54 & 45 \\
\hline 13 & 40 & 40 & 46 & 48 & 48 & 44 \\
\hline 14 & 40 & 41 & 32 & 48 & 44 & 48 \\
\hline 15 & 53 & 40 & 48 & 34 & 45 & 45 \\
\hline 16 & 43 & 41 & 46 & 42 & 44 & 51 \\
\hline Média & 43,5 & 41,8 & 43,1 & 44,3 & 44,4 & 46,6 \\
\hline Média + $10 \%$ & 47,85 & 45,98 & 47,41 & 48,73 & 48,84 & 51,26 \\
\hline Média - 10\% & 39,15 & 37,62 & 38,79 & 39,87 & 39,96 & 41,94 \\
\hline IE & 42,4 & 41,5 & 42,7 & 44,4 & 43,7 & 46,6 \\
\hline Fck (MPa) & $37,7 \pm 6,0$ & $36,3 \pm 6,0$ & $38,2 \pm 6,0$ & $40,8 \pm 6,5$ & $39,8 \pm 6,0$ & $44,4 \pm 6,5$ \\
\hline
\end{tabular}


Após os ensaios de esclerometria, foi feito o ensaio à compressão simples do concreto extraindo um testemunho em cada área delimitada para o ensaio, conforme as imagens a seguir:

Figura 7.11 - Ensaio de esclerometria da instituição privada

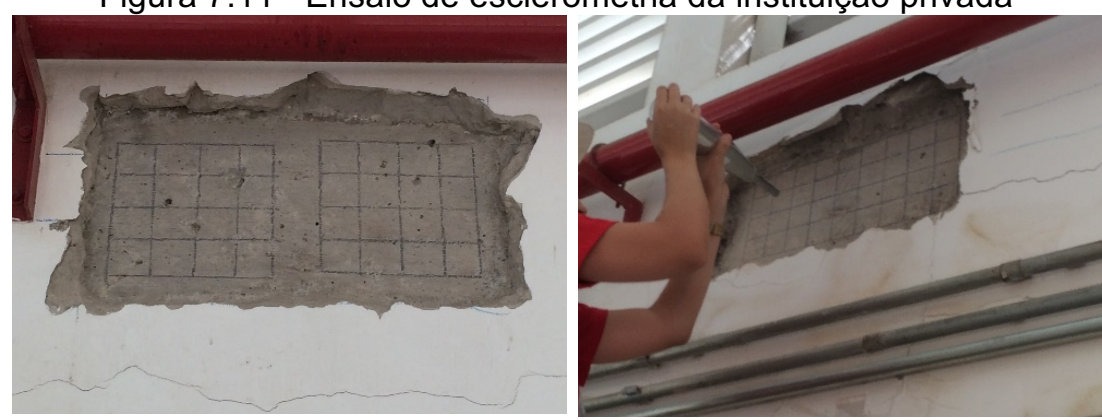

Figura 7.12 - Extração do corpo-de-prova da instituição privada

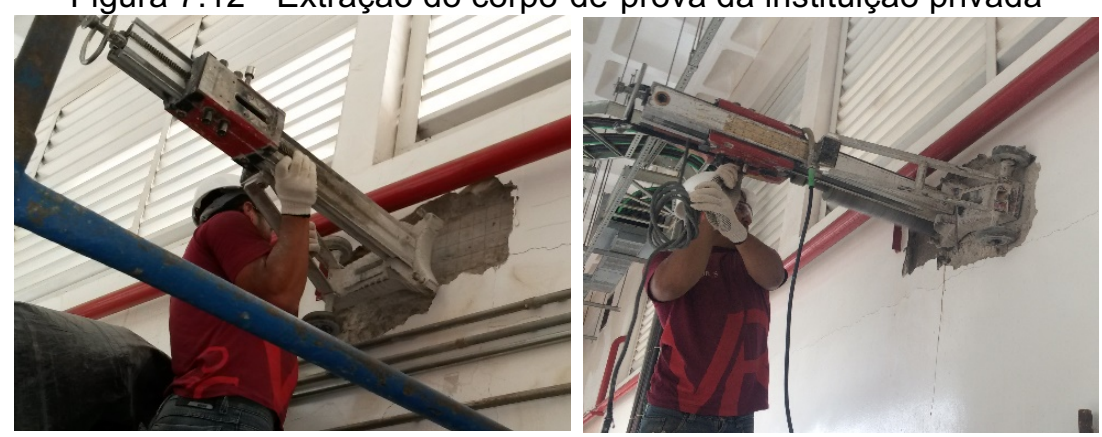

Figura 7.13 - Extração do testemunho da instituição privada
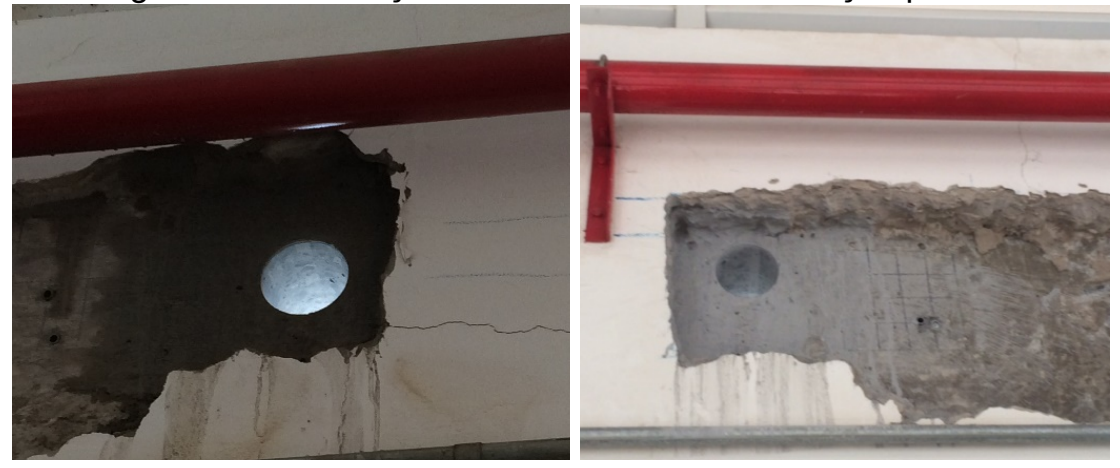

Antes de caracterizar os testemunhos ensaiados, estes foram cortados, utilizando serra diamantada dotada de refrigeração à água (retifica) e rompidos os testemunhos de concreto, conforme as figuras 7.14. 
Figura 7.14 - Ensaio de resistência à compressão simples

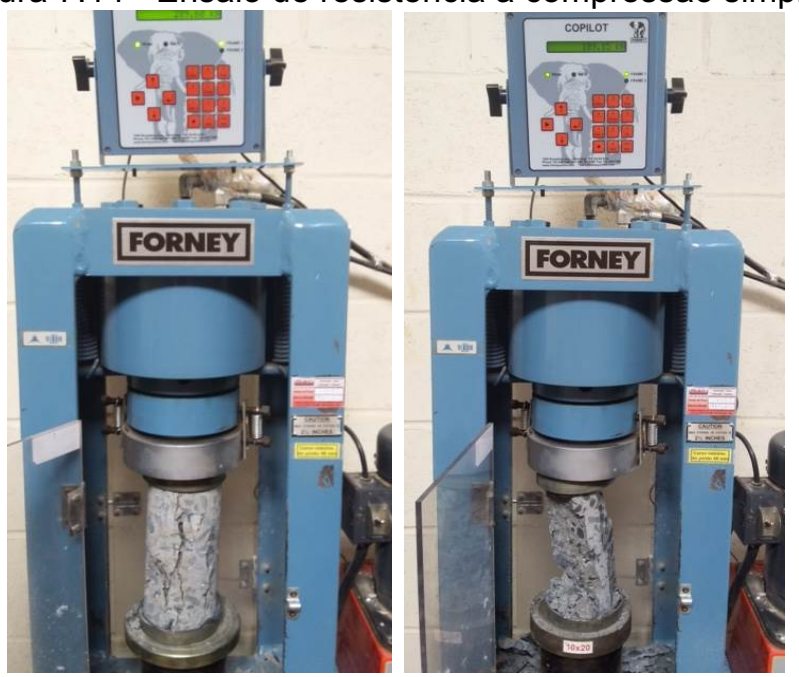

Os resultados de resistência à compressão dos corpos-de-prova estão apresentados na Tabela 7.11, o qual percebeu-se que os resultados foram elevados, tendo uma média de resistência a compressão 36,95 MPa, notando que o problema das fissuras não foi devido a qualidade do concreto.

Tabela 7.11 - Resultados de resistência à compressão do concreto

\begin{tabular}{|c|c|c|c|c|c|}
\hline \multirow{2}{*}{$\begin{array}{c}\text { Corpo de } \\
\text { Prova }\end{array}$} & \multicolumn{5}{|c|}{ ELEMENTOS } \\
\cline { 2 - 6 } & Resistência (MPa) & Força $(\mathrm{kN})$ & Comprimento $(\mathrm{cm})$ & Diâmetro $(\mathrm{cm})$ & Massa $(\mathrm{g})$ \\
\hline CP-01 & 36,9 & 289,60 & 19,7 & 10 & 3711,7 \\
\hline CP-02 & 41,5 & 325,80 & 19,5 & 10 & 3675,8 \\
\hline CP-03 & 38,7 & 303,80 & 19,6 & 10 & 3592,2 \\
\hline CP-04 & 24,1 & 189,15 & 19,5 & 10 & 3574,9 \\
\hline CP-05 & 44,8 & 352,00 & 19,3 & 10 & 3589,7 \\
\hline CP-06 & 35,7 & 280,00 & 19,9 & 10 & 3674,6 \\
\hline
\end{tabular}

A seguir apresenta-se a figura 7.15 com os resultados de resistência obtidos pelos ensaios de esclerometria e de resistência a compressão. 
Figura 7.15 - Comparação do ensaio de esclerometria e de resistência a compressão

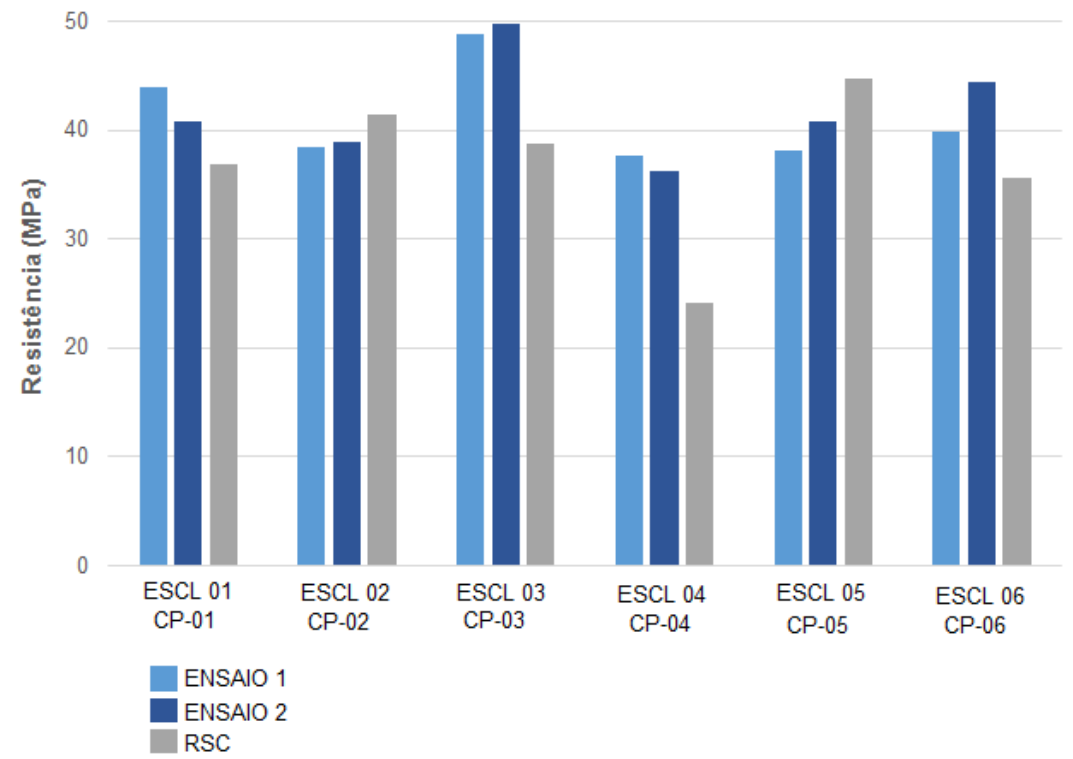




\section{CONSIDERAÇÕES FINAIS}

Neste trabalho foram apresentados, além da revisão bibliográfica sobre ensaios não destrutivos, semi destrutivos e critérios de projeto que visam a durabilidade do concreto, análise de duas edificações localizadas no Plano Piloto DF, o qual, a primeira que consiste na instituição pública, tinha como objetivo levantamento da estrutura para realização de uma reforma e, o outro que era instituição privada, um prognóstico das manifestações patológicas.

O primeiro prédio, de instituição pública, obteve resultados coerentes nos métodos utilizados, sendo que, no ensaio de frente de carbonatação, não constatou a presença de carbonatação do concreto, devido a proteção empenhada pelo reboco e pintura, além da qualidade do concreto.

No ensaio de detecção eletromagnética, cumpriu-se com o objetivo de realizar o levantamento da armação de todos os pilares e verificou que o cobrimento nominal não estava de acordo com norma atual, ABNT NBR 6118:2014. Já o ensaio de pulso ultrassônico, conseguiu analisar a tecnologia do aparelho e o comportamento do concreto dos pilares ensaiados, que consistiu em concretos de boa e média qualidade.

No ensaio de esclerometria, foi obtido a resistência superficial do concreto para cada pilar, onde o valor mínimo da resistência à compressão variou entre 23,54 MPa no P20, localizado no primeiro pavimento, a 37,5 MPa para o pilar P09, localizado no pavimento térreo, considerando a margem de erro do ensaio. Por fim, o ensaio de resistência a compressão do concreto com extração de corpo de testemunho que obteve resultados adequados e mesmo com descarte de um dos corpos de prova, ainda foi possível analisar a estrutura, que resultou na resistência de cálculo média de compressão do concreto (fcd) de 22,1 MPa.

Nessa perspectiva, com relação aos equipamentos utilizados na pesquisa, pode-se concluir que o pacômetro e o ultra-som se mostraram adequados ao estudo proposto, no que se refere a tecnologia de detecção de armaduras e condições de fissuração dos elementos estruturais.

Contudo, mesmo com a idade avançada da edificação pública, após todos os ensaios efetuados nos pilares, pode-se verificar que a estrutura de concreto armado encontra-se em bom estado de conservação, sem deterioração precoce, porém necessitando de intervenções nas instalações elétricas e hidráulicas, bem como 
estrutura externa da edificação e reforço estrutural, de modo a garantir uma maior vida útil a edificação.

A edificação privada, resultou em dados coesos para o cumprimento do objetivo da edificação, o qual os métodos utilizados foram de suma importância para análise, sendo eles, o ensaio de detecção eletromagnética que a utilização era somente para a construção da malha, ensaio de dureza superficial, que obteve a resistência superficial do concreto nos pilares ensaiados, onde o valor mínimo da resistência à compressão variou entre $31,7 \mathrm{MPa}$ no ensaio 01 do pilar 04 a 43,3 MPa no ensaio 2 do pilar 03, considerando a margem de erro do ensaio. Por último, o ensaio de resistência a compressão do concreto com extração de corpo de testemunho que obteve resultados adequados com o mínimo sendo 24,1 MPa.

A edificação privada demandará recuperação das fissuras estruturais nas vigas bem como, instalação de proteção térmica na cobertura para redução da temperatura, principal causa da fissuração estrutural.

Ao final, baseado na vistoria e ensaios, obteve-se resultados satisfatório de acordo com os respectivos objetivos, além da possibilidade de análise conjunta entre os ensaios realizados em cada estrutura. Concluiu-se que as edificações não apresentaram, ao longo da vida útil, deterioração precoce, tendo em vista, que são estruturas com mais de 50 anos de idade. 


\section{REFERÊNCIAS BIBLIOGRÁFICAS}

ACI COMMITTEE 228, Nondestructive Test Methods for Evaluation of Concrete in Structures, American Concrete Institute, ACI 228.2R, 1998.

ANDRADE, M. D. C. Manual para diagnóstico de obras deterioradas por corrosão de armaduras. São Paulo: Pini, 1992. 104p.

ASSOCIAÇÃO BRASILEIRA DE NORMAS TÉCNICAS. NBR 5738: concreto procedimento para moldagem e cura de corpos de prova, 2016. 13p.

ASSOCIAÇÃO BRASILEIRA DE NORMAS TÉCNICAS. NBR 5739: concreto ensaio de compressão de corpos de prova cilíndricos, 2007. 9p.

ASSOCIAÇÃO BRASILEIRA DE NORMAS TÉCNICAS. NBR 6118: Projeto de estruturas de concreto - Procedimento, 2014. 238p.

ASSOCIAÇÃO BRASILEIRA DE NORMAS TÉCNICAS. NBR 7584: concreto endurecido - avaliação da dureza superficial pelo esclerômetro de reflexão, 2012. $10 p$.

ASSOCIAÇÃO BRASILEIRA DE NORMAS TÉCNICAS. NBR 7680-1: concreto extração, preparo e ensaio de testemunhos de concreto, 2015. 27p.

ASSOCIAÇÃO BRASILEIRA DE NORMAS TÉCNICAS. NBR 8802: concreto endurecido - determinação da velocidade de propagação de onda ultra-sônica, 2013. $8 p$.

ASSOCIAÇÃO BRASILEIRA DE NORMAS TÉCNICAS. NBR 12655: concreto de cimento Portland - Preparo, controle, recebimento e aceitação - Procedimento, 2015.

BRANDÃO, A. M. S. Qualidade e durabilidade das estruturas de concreto armado. São Carlos, 1998. 149p.

BRITISH STANDARD INSTITUTION, BS 1881: Part 201, 1986, "Guide to the use of nondestructive methods of test for hardned concrete", London.

CACHIM, P.; CARASEK, H.; CASCUDO, O.; FIGUEIREDO, C. P.; SANTOS, F. B.; VELOSA, A.; O papel do metacaulim na proteção dos concretos contra a ação deletéria de cloretos. IBRACON STRUCTURES AND MATERIALS JOURNAL, 2014. V. 7, No 4, p. 685-708

CÂMARA, E. Avaliação da resistência à compressão do concreto utilizado usualmente na grande florianópolis através de métodos de ensaios não destrutivos. Florianópolis, 2006. 152p. 
CUNHA, A.C.Q.; HELENE, P.R.L. Despassivação das armaduras de concreto por ação da carbonatação. Boletim técnico da Escola Politécnica da Universidade de São Paulo - BT/PCC/283. São Paulo, 2001.

DIAS, J. F.; FERREIRA, G.; SILVA, T. J. Influência de variáveis nos resultados de ensaios não destrutivos em estruturas de concreto armado. Ciência \& Engenharia, v. 22, n. 1, 2013.

EN-ISO 8047: Testing concrete - Determination of ultrasonic pulse velocity, Brussels, 1994.

EVANGELISTA, A. C. J. Avaliação de resistência do concreto usando diferentes ensaios não destrutivos. Rio de Janeiro, 2002. 8p.

FRANÇA, C. B. Avaliação de cloretos livres em concreto pelo método de aspersão de solução de nitrato de prata. Recife, 2011. 105p.

FIGUEIREDO, E. P. Efeitos da carbonatação e de cloretos no concreto. In: ISAIA, G.C. Concreto: ensino, pesquisa e realizações. v. 2, cap.27. São Paulo: IBRACON, 2005. 829-855p.

HELENE, P., (2001). Introdução da vida útil no projeto das estruturas de concreto NB/2001. WORKSHOP SOBRE DURABILIDADE DAS CONSTRUÇÕES. Novembro. São José dos Campos.

IBAPE/SP - Instituto Brasileiro de Avaliações e Perícias de Engenharia de São Paulo - Norma de Inspeção Predial, 2011.

MEHTA, P. K.; MONTEIRO, P. J. M. Concreto: microestrutura, propriedades e materiais. 2 ed. São Paulo: Ibracon, 2014.

MENEGHETTI L. C. Avaliação de estruturas acabadas. Conteúdo da disciplina optativa Patologia e recuperação de estruturas de concreto. Cascavel. PR: Universidade Estadual do Oeste de Paraná. 2009. 34p.

NEVILLE, A. M. Propriedades do concreto. 5. ed. Porto Alegre: Bookman, 2016.

SAHUINCO, M. H. Utilização de métodos não destrutivos e semi- destrutivos na avaliação de pontes de concreto. São Paulo, 2011. 170p.

SANTOS, M. R. Deterioração das estruturas de concreto armado - Estudo de caso. Belo Horizonte, 2012. 122p.

STRUCTURES AND MATERIALS JOURNA. O papel do metacaulim na proteção dos concretos contra a ação deletéria de cloretos. Vol.7, n4: Ibracon, 2014.

TULA, L. S. Contribuição ao Estudo da Resistência à Corrosão de Armaduras de Aço Inoxidável. São Paulo, 2000. 259p. Tese (Doutorado) - Escola Politécnica, Universidade de São Paulo. 